\title{
Borehole Data Package for RCRA Wells 299-E25-93 and 299-E24-22 at Single-Shell Tank Waste Management Area A-AX, Hanford Site, Washington
}

\author{
B. A. Williams \\ S. M. Narbutovskih
}

December 2003

Prepared for the U.S. Department of Energy under Contract DE-AC06-76RL01830 


\title{
DISCLAIMER
}

This report was prepared as an account of work sponsored by an agency of the United States Government. Reference herein to any specific commercial product, process, or service by trade name, trademark, manufacturer, or otherwise does not necessarily constitute or imply its endorsement, recommendation, or favoring by the United States Government or any agency thereof, or Battelle Memorial Institute.

\author{
PACIFIC NORTHWEST NATIONAL LABORATORY \\ operated by \\ BATTELLE \\ for the \\ UNITED STATES DEPARTMENT OF ENERGY \\ under Contract DE-AC06-76RL01830
}

\author{
Printed in the United States of America \\ Available to DOE and DOE contractors from the \\ Office of Scientific and Technical Information, P.O. Box 62, Oak Ridge, TN 37831; \\ prices available from (615) 576-8401. \\ Available to the public from the National Technical Information Service, \\ U.S. Department of Commerce, 5285 Port Royal Rd., Springfield, VA 22161
}




\section{Borehole Data Package for RCRA}

Wells 299-E25-93 and 299-E24-22 at Single-Shell Tank Waste Management Area A-AX, Hanford Site, Washington

B. A. Williams

S. M. Narbutovskih

December 2003

Prepared for

the U.S. Department of Energy

under Contract DE-AC06-76RL01830

Pacific Northwest National Laboratory

Richland, Washington 99352 


\section{Summary}

Two new Resource Conservation and Recovery Act (RCRA) groundwater monitoring wells were installed at single-shell tank Waste Management Area (WMA) A-AX in fiscal year 2003 to fulfill commitments for well installations proposed in the draft Hanford Federal Facility Agreement and Consent Order M-24-00. Well 299-E24-22 has been installed upgradient and well 299-E25-93 downgradient of the WMA. Specific objectives for these wells include monitoring the impact, if any, that potential releases from inside the WMA may have on current groundwater conditions (i.e., improved network coverage); differentiating upgradient groundwater contamination from contaminants released at the WMA; and improving the determination of groundwater flow direction (i.e., improved water table determinations).

This report supplies the information obtained during drilling, characterization, and installation of the two new groundwater monitoring wells, 299-E25-93 and 299-E24-22. This document also provides a compilation of hydrogeologic and well construction information obtained during drilling, well construction, well development, pump installation, aquifer testing, and sample collection/analysis activities. 


\section{Contents}

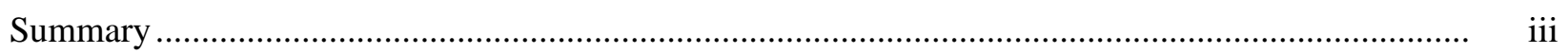

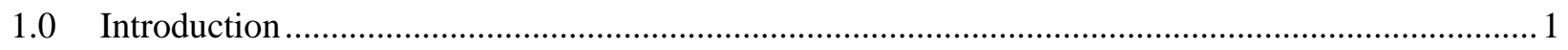

1.1 New Groundwater Monitoring Wells ......................................................................... 1

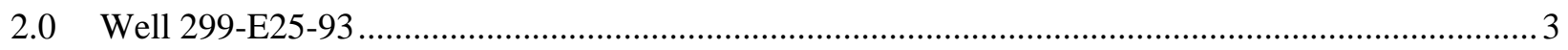

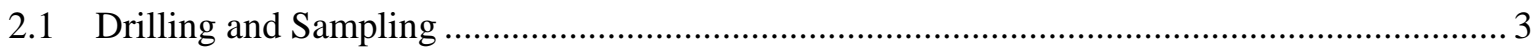

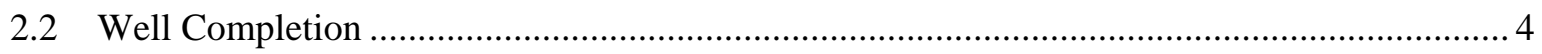

2.3 Well Development and Pump Installation............................................................... 4

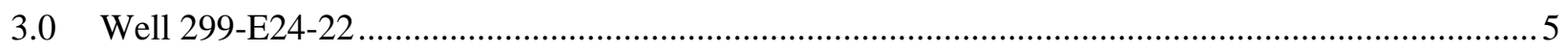

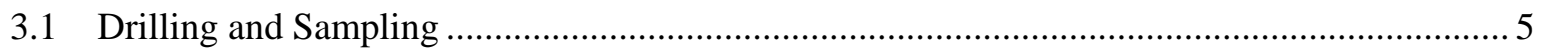

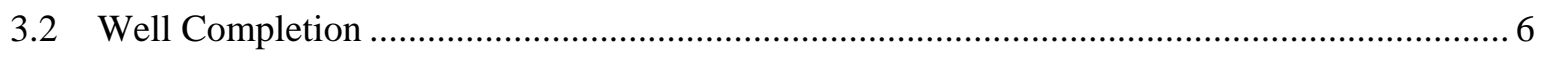

3.3 Well Development and Pump Installation................................................................... 7

4.0 Sampling and Analysis During Drilling ................................................................................ 7

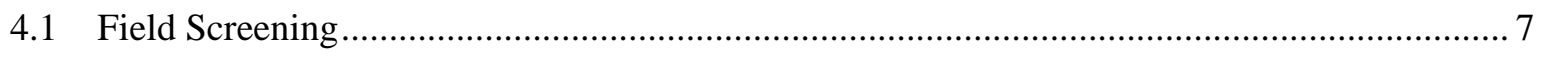

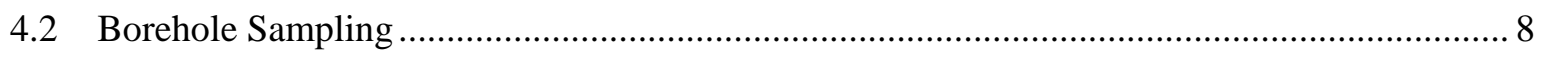

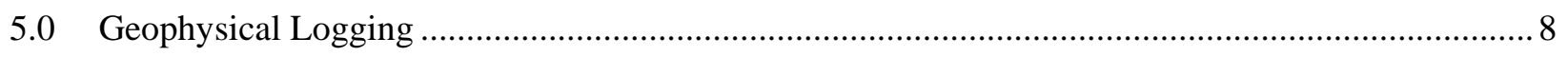

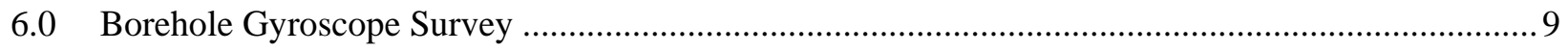

7.0 Subsurface Characterization Results and Interpretation ........................................................... 10

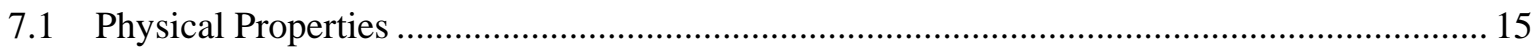

7.2 Sediment Digital Photographic Log ............................................................................ 15

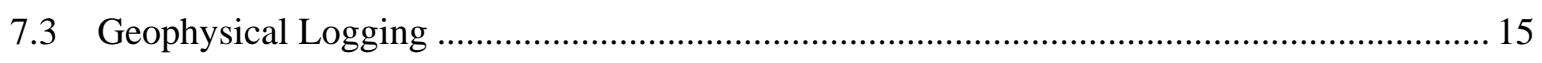

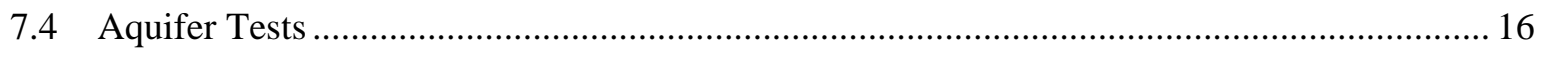

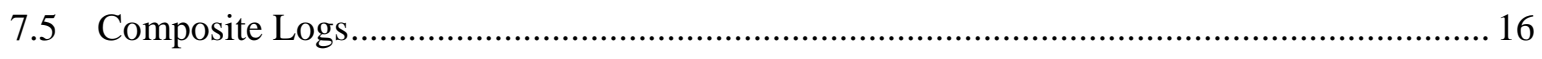

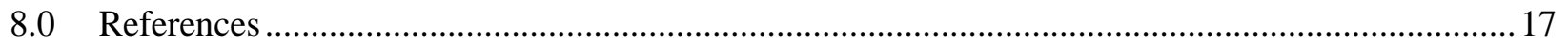


Appendix A - Well Construction and Completion Documentation

A.1

Appendix B - Sediment Samples Physical Properties Data

B.1

Appendix C - Borehole Geophysical Logs Gyroscope Surveys ..................................................... C.1 


\section{Figures}

1 Map of Single-Shell Tank Waste Management Area A-AX and Locations of New and Existing Wells in the Groundwater Monitoring Network ................................................................................ 2

2 Vertical Profile and Bottom Hole Projections of Well 299-E25-93 ..................................................... 9

3 Vertical Profile and Bottom Hole Projections of Well 299-E24-22 .................................................. 10

4 Hydrogeologic Interpretation for Well 299-E25-93 near Single-Shell Tank Farm WMA A-AX......... 11

5 Hydrogeologic Interpretation for Well 299-E24-22 near Single-Shell Tank Farm WMA A-AX......... 13

\section{Tables}

1 Survey Data for Wells 299-E25-93 and 299-E24-22 ............................................................... 4

2 Well Development Information for Well 299-E25-93.................................................................... 5

3 Well Development Information for Well 299-E24-22 ............................................................... 7 


\subsection{Introduction}

Two new Resource Conservation and Recovery Act (RCRA) groundwater monitoring wells were installed at single-shell tank Waste Management Area (WMA) A-AX in fiscal year 2003 to fulfill commitments for well installations proposed in draft Hanford Federal Facility Agreement and Consent Order (Tri-Party Agreement; Ecology et al. 1998) Milestone M-24-57 (Murphy-Fitch 2003). ${ }^{\text {(a) }}$ The need for increased monitoring capability was identified in Narbutovskih and Horton (2001) and during a data quality objectives process for establishing an RCRA/Comprehensive Environmental Response, Compensation, and Liability Act (CERCLA)/Atomic Energy Act of 1954 (AEA) integrated 200 West and 200 East Area Groundwater Monitoring Network (Byrnes and Williams 2003).

One outcome of the data quality objective process was a requirement to install additional groundwater monitoring wells in the immediate vicinity of WMA A-AX. Two wells have been installed; one located upgradient and one downgradient of the WMA (Figure 1). Specific objectives for these wells include monitoring the impact, if any, that potential releases from the WMA may have on current groundwater conditions (i.e., improved network coverage); differentiating upgradient groundwater contamination from contaminants released at the WMA; and improving the determination of groundwater flow direction (i.e., improved water table determinations). This report provides the information obtained during drilling, characterization, and installation of the two new groundwater monitoring wells at the single-shell tank WMA A-AX.

\subsection{New Groundwater Monitoring Wells}

The two new groundwater monitoring wells were installed between July and September 2003. The wells are identified as 299-E25-93 (well ID C4122) and 299-E24-22 (well ID C4123) and shown on a location map in Figure 1. The new wells were constructed to the specifications and requirements described in Washington Administrative Code (WAC) 173-160, and the groundwater monitoring description of work for drilling and installation (Williams 2003) and specifications used by Fluor Hanford, Inc. (FHI) for well drilling and construction. During drilling and construction of the wells, sampling and analysis activities were conducted to support screening for radiological contaminants and to collect sediment grab samples for geologic descriptions and for archiving in the Hanford Geotechnical Sample Library located at Building 3718A/B in the 300 Area.

This document provides a compilation of hydrogeologic and well construction information obtained during drilling, well construction, well development, pump installation, aquifer testing, and sample collection/analysis activities. Appendix A contains the Well Summary Sheets (as-built diagrams), the Well Construction Summary Report, the geologist's borehole log, well development and pump installation reports, and the well survey records. Appendix B contains results of field and/or laboratory determinations of physical properties of sediment samples. Appendix C contains borehole geophysical logs and

borehole deviation survey results. Additional well construction documentation is on file with FHI in

(a) Letter from EJ Murphy-Fitch (Fluor Hanford Inc., Richland, Washington) to Distribution, "Tentative Agreement on Tri-Party Agreement Negotiations on the Overall Strategy and Approach for Hanford Groundwater Protection, Monitoring, and Remediation (M-024),” dated September 22, 2003. 


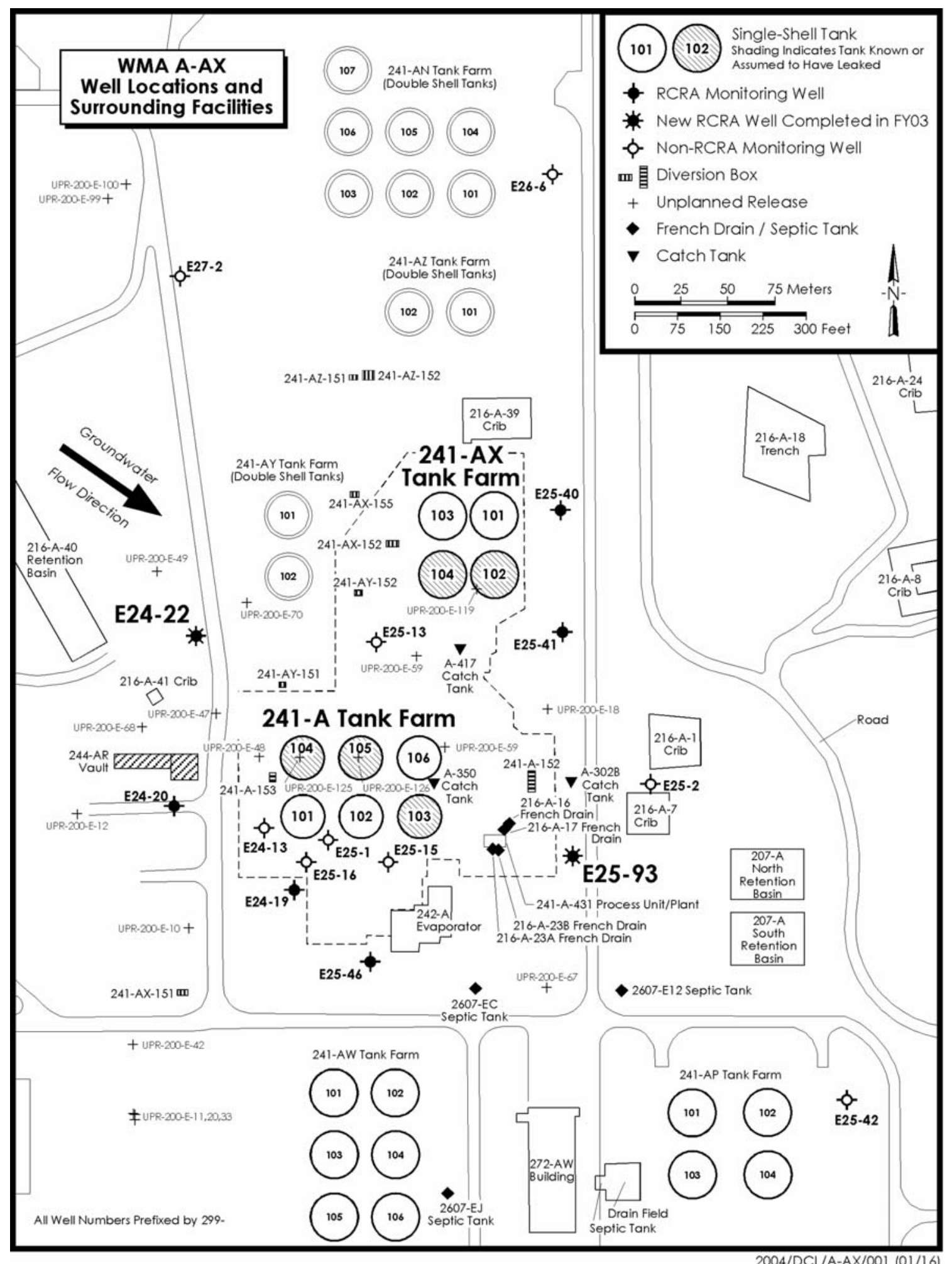

Figure 1. Map of Single-Shell Tank Waste Management Area A-AX and Locations of New and Existing Wells in the Groundwater Monitoring Network 
Richland, Washington. The Records Management Information System and the Hanford Well Information System [http://apweb02/cfroot/rapidweb/phmc/cp/hwisapp/] are two electronic databases that also contain the drilling and construction records for these two wells.

English units are used in this report to describe drilling and well completion activities because that is the system of units used by drillers to measure and report depths and well construction measurements. Conversion to metric can be done by multiplying feet by 0.3048 to obtain meters or by multiplying inches by 2.54 to obtain centimeters.

\subsection{Well 299-E25-93}

Well 299-E25-93 is located along the southeast side of the 241-A tank farm (Figure 1). The well is downgradient of WMA A-AX and will help determine if contaminants are released from the WMA.

\subsection{Drilling and Sampling}

Well 299-E25-93 (well ID C4122) was drilled with a dual wall percussion rig (Becker-hammer) from surface to a total depth of 320 feet below ground surface (bgs). Temporary 9-inch-outside-diameter, dualwall casing was used during drilling from the surface to total depth. Borehole drilling began on July 1 and total depth was reached on July 2, 2003.

Grab samples of sediment for geologic description and archive were collected at approximately 5-foot intervals from ground surface to total depth. Also, one 2-foot-long, 4-inch-diameter split spoon sample was attempted from the proposed screen interval for physical property analysis (sieve analysis) to confirm screen selection. The split spoon attempt was unsuccessful, so grab samples from the drill cuttings return line were collected from the screen interval (at 281 feet bgs and 316 feet bgs).

Sediments encountered during drilling consisted of backfill material and recent sediments (Holocene) deposited to a depth of approximately 10 feet bgs, Hanford formation sediments composed of sand to gravelly sand to sandy gravel from 10 feet bgs to about 266 feet bgs, and the sandy gravel of the lower Hanford formation and/or the mainstream alluvial facies of the Cold Creek unit from 266 feet bgs to approximately 317 feet bgs. Ringold Formation silty sandy gravel is indicated from 317 to 320 feet bgs total depth. The wellsite geologist's detailed lithologic borehole log and 5-foot depth interval sediment descriptions are included in Appendix A. A more complete hydrogeologic interpretation of the borehole sediments is included in Chapter 7.

The borehole and drill cuttings were monitored regularly for organic vapors and radionuclide contaminants (i.e., for alpha, beta, and gamma). Organics were not detected. The well was geophysically logged on July 7, 2003, by Stoller Corporation. Geophysical logging indicated that a slight amount of manmade cesium-137 was detected near ground surface ( $4.9 \mathrm{pCi} / \mathrm{g}$ maximum concentration) and at scattered intervals down to 195 feet bgs (Appendix C). Chapter 5 provides more details of geophysical logging. 


\subsection{Well Completion}

The permanent casing and screen was installed in well 299-E25-93 in July 2003. A 35-foot-long, 4-inch-inner-diameter, stainless steel, continuous wire-wrap (0.02-inch slot) screen was set from 278.23 to 313.26 feet bgs. Below the screen interval there is a 2-foot-long stainless steel sump placed from 313.26 to 315.26 feet bgs. The permanent well casing is 4-inch-inside-diameter, stainless steel from 278.23 feet bgs to 2 feet above ground surface.

The screen filter pack is 10-20 mesh silica sand placed from 273.1 to 320 feet bgs. The sand pack was settled and initial development completed using a dual-flange surge block. The annular seal is composed of bentonite pellets from 268.5 to 273.1 feet bgs and bentonite crumbles from 10.5 to 268.5 feet bgs. The surface seal is composed of Portland cement grout from 10.5 feet bgs to ground surface. A 4-foot by 4-foot by 6-inch concrete pad was placed around the well at the surface. A protective well head casing with locking cap, four protective steel posts, and a brass marker stamped with the well ID number and Hanford well number were set into the concrete pad. The Well Construction Summary Report and Well Summary Sheet (as-built) are included in Appendix A.

A vertical borehole deviation survey was conducted utilizing a downhole gyroscope in the completed well to determine the well bottom location relative to a vertical borehole projection. Survey results are discussed in Chapter 6 and located in Appendix C.

The elevation and geographic coordinates of the well were surveyed by Fluor Federal Services on October 31, 2003. The horizontal position of the well was referenced to horizontal control stations established by the U.S. Army Corps of Engineers (USACE). The coordinates are Washington State Plane Coordinate System, South Zone, NAD83(91) datum. Vertical datum is NAVD88 and is based on existing USACE bench marks. Survey data are included in Table 1 and Appendix C. The static water level was 278.04 feet bgs on July 15, 2003.

\subsection{Well Development and Pump Installation}

Well 299-E25-93 was developed on August 14, 2003. Well development was performed at three different intervals. A temporary, 5-horsepower submersible pump was used for development. Depth-to-

Table 1. Survey Data for Wells 299-E25-93 and 299-E24-22

\begin{tabular}{|c|c|c|c|c|}
\hline $\begin{array}{l}\text { Well Name (Well } \\
\text { ID) }\end{array}$ & $\begin{array}{l}\begin{array}{l}\text { Easting } \\
(\mathrm{m})\end{array} \\
\end{array}$ & $\begin{array}{c}\text { Northing } \\
(\mathrm{m})\end{array}$ & $\begin{array}{l}\text { Elevation } \\
(\mathrm{m})\end{array}$ & Comments \\
\hline \multirow{4}{*}{$\begin{array}{l}\text { 299-E25-93 } \\
\text { (C4122) }\end{array}$} & $575,471.51$ & $136,022.09$ & & Center of casing \\
\hline & & & 208.040 & Top of casing, N. edge \\
\hline & & & 207.265 & Brass survey marker \\
\hline & & & 208.046 & Top pump base plate, N. edge \\
\hline \multirow{4}{*}{$\begin{array}{c}\text { 299-E24-22 } \\
\text { (C4123) }\end{array}$} & $575,262.68$ & $136,142.82$ & & Center of casing \\
\hline & & & 210.285 & Top of casing, N. edge \\
\hline & & & 209.553 & Brass survey marker \\
\hline & & & 210.291 & Top pump base plate, N. edge \\
\hline
\end{tabular}


water level was measured at 281.26 feet below top of casing (btc) prior to development. A pressure transducer was installed above the pump and connected to a Hermit datalogger to monitor water level during development. Table 2 contains the results of final well development, including pump intake depth, pump rate, pump run time, drawdown, recovery time, final turbidity (NTU), and stabilized conductivity and temperature readings. A total of 4,547 gallons of water was pumped.

A dedicated Redi-Flo-3, 0.7-horsepower Grundfos ${ }^{\mathrm{TM}}$ submersible sampling pump was installed in well 299-E25-93 on September 16, 2003. The sampling pump intake was set at 286.1 feet btc, approximately 5 feet below the water table, and connected to the surface with 3/4-inch-diameter stainless steel riser pipe.

Table 2. Well Development Information for Well 299-E25-93

\begin{tabular}{|c|c|c|c|c|c|}
\hline Pump Rate & $\begin{array}{l}\text { Pump Intake } \\
\text { Depth (ft btc) }\end{array}$ & $\begin{array}{l}\text { Pumping } \\
\text { Run Time } \\
\text { (min) }\end{array}$ & $\begin{array}{l}\text { Drawdown } \\
\text { (ft) }\end{array}$ & Final Readings & $\begin{array}{c}\text { Recovery Test } \\
\text { Time (min) }\end{array}$ \\
\hline 25.5 gpm & 316.1 & 59 & 0.2 & $1.26 \mathrm{NTU}, 564 \mu \mathrm{s} / \mathrm{cm}, 20.4 \mathrm{C}$ & $11(99.8 \%)$ \\
\hline 26 gpm & 306 & 64 & $<0.1$ & $0.83 \mathrm{NTU}, 550 \mu \mathrm{s} / \mathrm{cm}, 21.6 \mathrm{C}$ & $14(100 \%)$ \\
\hline $26 \mathrm{gpm}$ & 296 & 53 & $<0.1$ & $1.19 \mathrm{NTU}, 555 \mu \mathrm{s} / \mathrm{cm}, 20.6 \mathrm{C}$ & $10(100 \%)$ \\
\hline \multicolumn{6}{|c|}{$\begin{array}{l}\mathrm{ft} \text { btc }=\text { Feet below top of casing. } \\
\text { gpm }=\text { Gallons per minute. } \\
\text { min }=\text { Minutes. } \\
\text { NTU }=\text { Nephelometric turbidity unit. } \\
\mu \mathrm{s} / \mathrm{cm}=\text { micro siemen per centimeter. }\end{array}$} \\
\hline
\end{tabular}

\subsection{Well 299-E24-22}

Well 299-E24-22 is located on the west side of the tank farm (Figure 1). The well is upgradient of the WMA A-AX and will help differentiate upgradient groundwater contamination from contaminants released at the WMA.

\subsection{Drilling and Sampling}

Well 299-E24-22 (well ID C4123) was also drilled with a Becker -hammer rig from surface to a total depth of 330 feet bgs. Temporary 9-inch-outside-diameter, dual-wall casing was used for drilling throughout the borehole to total depth. Borehole drilling began on July 10 and reached total depth on July 11, 2003.

Grab samples of sediment for geologic description and archive were collected at approximately 5-foot intervals from ground surface to total depth. Also, one 2-foot-long, 4-inch-diameter split spoon sample was attempted from the proposed screen interval for sieve analysis to confirm screen selection. The split spoon retrieved $100 \%$ of sample from 286 to 288.5 feet bgs; a grab sample was also collected from the drill cuttings return line at $\sim 321$ feet bgs for sieve analysis. 
Sediments encountered during drilling consist of backfill and recent sediments (Holocene) deposited to a depth of approximately 8 feet bgs, Hanford formation sediments composed of sand to gravelly sand to sandy gravel from 8 feet bgs to about 300 feet bgs, and the sandy gravel of the lower Hanford formation and/or the Cold Creek unit from 300 feet bgs to total depth (330 feet bgs). A distinct silt/clay layer was encountered from 267 to 272 feet bgs. A more complete hydrogeologic interpretation of the borehole sediments is included in Chapter 7. A detailed lithologic borehole log is provided in Appendix A.

The borehole and drill cuttings were monitored regularly for organic vapors and radionuclide contaminants (i.e., for alpha, beta, and gamma). Organic vapor analysis detected 3.6 to 3.8 parts per million organics in the borehole at 300 feet bgs. The well was geophysically logged between July 12 and July 15, 2003, by Stoller Corporation. Geophysical logging indicated that a slight amount of manmade cesium137 was detected at scattered intervals down to 125 feet bgs (Appendix C). Chapter 5 provides more details of geophysical logging.

\subsection{Well Completion}

The permanent casing and screen was installed in well 299-E24-22 in July 2003. A 35-foot-long, 4-inch-inner-diameter, stainless steel, continuous wire-wrap (0.02-inch slot) screen was set from 321.26 to 286.21 feet bgs. Below the screen interval, there is a 2-foot long stainless steel sump placed from 323.68 to 321.26 feet bgs. The permanent well casing is 4-inch-inside-diameter, stainless steel from 286.21 feet bgs to 2 feet above ground surface.

The screen filter pack is 10-20 mesh silica sand placed from 330 to 281.1 feet bgs total depth. The sand pack was settled and initial development completed using a dual-flange surge block. The annular seal is composed of bentonite pellets from 281.1 to 276.1 feet bgs and bentonite crumbles from 276.1 to 10 feet bgs. The surface seal is composed of Portland cement from 10 feet bgs to ground surface. A 4-foot by 4-foot by 6-inch concrete pad was placed around the well at the surface. A protective well head casing with locking cap, four protective steel posts, and a brass marker stamped with the well ID number and Hanford well number were set into the concrete pad. The Well Construction Summary Report and Well Summary Sheet (as-built) are included in Appendix A.

A vertical borehole deviation survey was conducted in the completed well to determine the well bottom location relative to a vertical projection. Survey results are discussed in Chapter 6 and located in Appendix C.

The vertical and horizontal coordinates of the well were surveyed by Fluor Federal Services in October 2003. The horizontal position of the well was referenced to horizontal control stations established by the U.S. Army Corps of Engineers. The coordinates are Washington State Plane Coordinate System, South Zone, NAD83(91) datum. Vertical datum is NAVD88 and is based on existing USACE bench marks. Survey data are included in Table 1 and Appendix C. The static water level was 286.02 feet bgs on July 17, 2003. 


\subsection{Well Development and Pump Installation}

Well 299-E24-22 was developed on September 8, 2003. Well development was performed at three different intervals. A temporary, 5-horsepower submersible pump was used for development. Depth to water level was measured at $\mathbf{2 8 8 . 9 4}$ feet btc prior to development. A pressure transducer was installed above the pump and connected to a Hermit ${ }^{\mathrm{TM}}$ datalogger to monitor water level during development. Table 3 contains the results of final well development, including pump intake depth, pump rate, pump run time, drawdown, recovery time, final turbidity, and stabilized conductivity and temperature readings. A total of 4,087 gallons of water was pumped.

A dedicated Redi-Flo-3, 0.7-horsepower, Grundfos ${ }^{\mathrm{TM}}$ submersible sampling pump was installed in well 299-E24-22 on September 8, 2003. The sampling pump intake was set $\sim 7$ feet below the water table at 296 feet btc and connected to the surface with 3/4-inch-diameter stainless steel riser pipe.

Table 3. Well Development Information for Well 299-E24-22

\begin{tabular}{|c|c|c|c|c|c|}
\hline $\begin{array}{l}\text { Pump Rate } \\
\text { (gpm) }\end{array}$ & $\begin{array}{l}\text { Pump Intake } \\
\text { Depth (ft btc) }\end{array}$ & $\begin{array}{l}\text { Pumping } \\
\text { Run Time } \\
\text { (min) }\end{array}$ & $\begin{array}{l}\text { Drawdown } \\
\text { (ft) }\end{array}$ & Final Readings & $\begin{array}{c}\text { Recovery Test } \\
\text { Time (min) }\end{array}$ \\
\hline 22.5 & 324.2 & 80 & 0.2 & $2.31 \mathrm{NTU}, 519 \mu \mathrm{s} / \mathrm{cm}, 18.2 \mathrm{C}$ & 24 (99.9\%) \\
\hline 24 & 314.2 & 63 & $<0.1$ & $2.25 \mathrm{NTU}, 366 \mu \mathrm{s} / \mathrm{cm}, 18.4 \mathrm{C}$ & $16(100 \%)$ \\
\hline 25 & 303.1 & 31 & $<0.1$ & $3.14 \mathrm{NTU}, 370 \mu \mathrm{s} / \mathrm{cm}, 18.5 \mathrm{C}$ & Not available \\
\hline $\begin{array}{l}\mathrm{ft} \mathrm{btc}= \\
\text { gpm }= \\
\text { Min }= \\
\text { NTU }= \\
\mu \mathrm{s} / \mathrm{cm}=\end{array}$ & $\begin{array}{l}\text { Feet below top } \\
\text { Gallons per min } \\
\text { Minutes. } \\
\text { Nephelometric t } \\
\text { micro siemens p }\end{array}$ & $\begin{array}{l}\text { asing. } \\
\text { idity unit. } \\
\text { centimeter. }\end{array}$ & & & \\
\hline
\end{tabular}

\subsection{Sampling and Analysis During Drilling}

This section describes the collection and analysis of sediment samples collected during drilling from wells 299-E25-93 and 299-E24-22.

\subsection{Field Screening}

Sediment samples were screened in the field prior to sample collection for indications of contamination. The drill cuttings and samples were screened for volatile organic contamination, beta-gamma activity, and alpha activity by radiation control technicians and safety staff. All radiation activity levels were at or below background for wells 299-E25-93 and 299-E24-22. Volatile organic screening was performed with a photo-ionization detector. No volatile organics were detected during drilling in well 299-E25-93, but 3.6 to 3.8 parts per million concentration was detected in the well 299-E24-22 at a depth of 300 feet bgs. No action was taken, and monitoring and drilling continued. 


\subsection{Borehole Sampling}

Sediment samples of drill cuttings were collected for geologic description (documented in the geologic borehole log) and archival from both boreholes at 5-foot intervals from ground surface to total depth. The geologic borehole logs are included in Appendix A. One-pint sediment samples collected in glass jars are archived in the Hanford Geotechnical Sample Library which is located at Building 3718A/B in the 300 Area.

Two split spoon samples were attempted from the interval to be screened at each borehole. In some cases, soil grab samples were used in lieu of split spoon samples because of incomplete sample recoveries or because the formation was not conducive to split spoon sampling. These samples were sieved for particle size distribution to provide data for screen slot size confirmation/selection. Sieve data and distribution curves are available in Appendix B.

All sediment sample depths are documented in the geologic borehole log for each well (located in Appendix A).

\subsection{Geophysical Logging}

A spectral gamma-ray borehole geophysical survey was conducted in both boreholes by Stoller Corporation. The spectral gamma-ray tool was used to determine the presence and concentration of manmade and naturally occurring gamma-emitting radionuclides in the boreholes. The geophysical logs have also been correlated with the geologic log data and the results are presented in Chapter 7 . The full suite of logs for both wells and detailed geophysical logging reports for the two wells are provided in Appendix C. The reports also describe calibration requirements, data processing, and log plots.

Well 299-E25-93 was logged on July 7, 2003 using high resolution, spectral gamma-ray instrumentation from ground surface to 320 feet bgs inside temporary dual-wall carbon steel casing with an approximate outside diameter of 9 inches. A repeat section was run from 320 to 288 feet bgs. Measurements were made at a "move-stop-acquire" mode and at a rate of 100 seconds per foot. Cesium-137 was the only gamma-emitting manmade radionuclide detected during geophysical logging. Cesium-137 was detected at ground surface with a maximum concentration of $4.9 \mathrm{pCi} / \mathrm{g}$. Cesium-137 was also detected sporadically at a few other depths throughout the borehole near the $0.3 \mathrm{pCi} / \mathrm{g}$ minimum detection limit. The geophysical logs are in Appendix C. Neutron-moisture logging was not completed because a dualwall casing was used and the casing diameter was too large for the calibrated neutron moisture tool.

In well 299-E24-22, logged between July 12 and 15, the spectral gamma-ray tool was run from ground surface to a depth of 328 feet bgs within the nominal 9-inch-diameter dual-wall temporary carbon steel casing. A repeat section was run from 105 to 72 feet bgs. Measurements were made at a "movestop-acquire” mode and at a rate of 200 seconds per foot. Cesium-137, a manmade radionuclide, was detected at a few depths throughout the borehole near the method detection limit $(0.3 \mathrm{pCi} / \mathrm{g})$. Neutronmoisture logging was not completed because a dual-wall casing was used and the casing diameter was too large for the calibrated tool. 


\subsection{Borehole Gyroscope Survey}

Downhole deviation (gyroscopic) surveys were performed in both wells following construction to determine the vertical and horizontal location coordinates of the screened interval (i.e., water table) relative to the borehole surface location and to determine the vertical dimension of the overall well. These data are used to determine the extent of borehole deviations created during drilling. The data can also be used to correct water-level elevations from depth-to-water measurements taken in the completed wells. Refer to Appendix $\mathrm{C}$ for the results of these surveys.

In well 299-E25-93, results indicate that at a measured cable depth of 305 feet, the true vertical depth of the well is 304.99 feet. (Note: This is not the drilled total depth). Figure 2 illustrates the vertical and horizontal offsets from the surface projection of well 299-E25-93. The correction factor for determining the true vertical elevation of the water table is $\sim 0.01 \mathrm{foot}$. This distance should be subtracted from the depth-to-water measurements to obtain true depth.

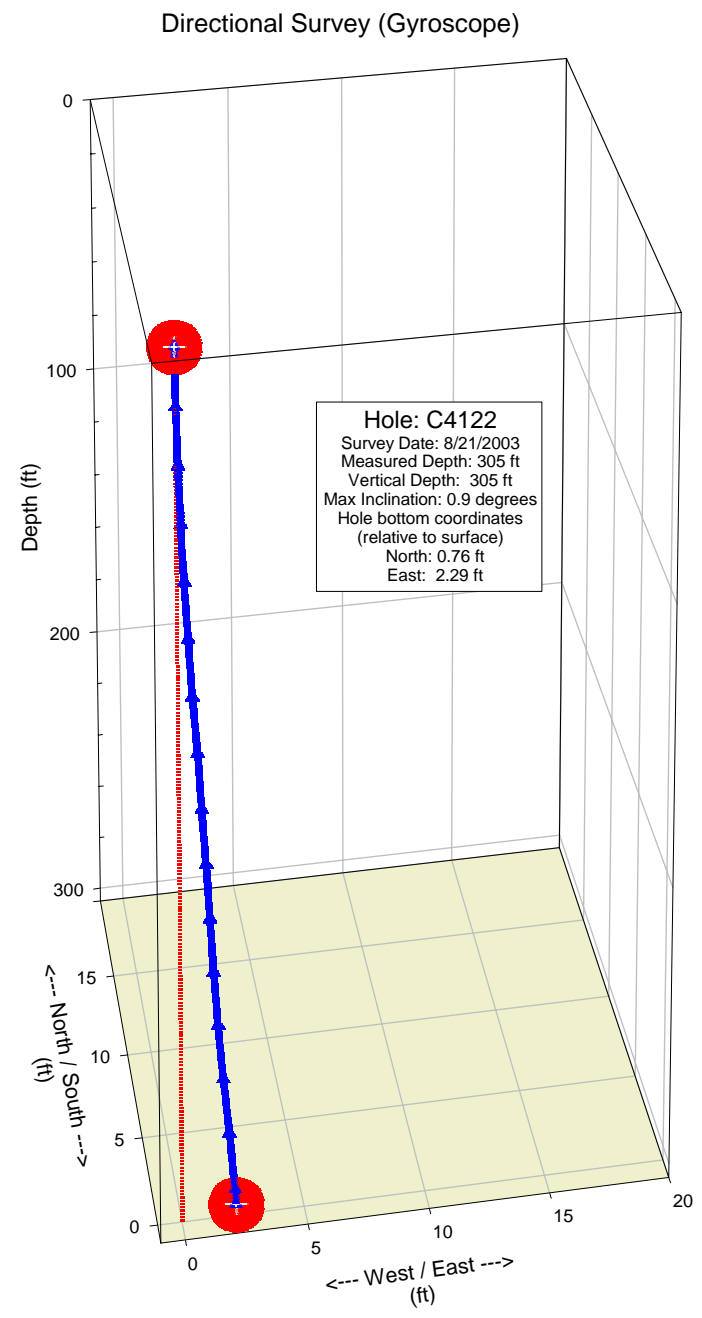

Figure 2. Vertical Profile and Bottom Hole Projections of Well 299-E25-93 
In well 299-E24-22, results indicate that at a measured cable depth of 312 feet, the true vertical depth of the well is 311.65 feet. (Note: This is not the drilled total depth). Figure 3 illustrates the vertical and horizontal offsets from the surface projection of well 299-E24-22. The measured depth-to-water table is approximately $286 \mathrm{ft}$ bgs and the correction factor at this depth for determining the true vertical elevation of the water table is $\sim 0.27$ foot. This distance should be subtracted from the depth-to-water measurements to obtain true depth.

\subsection{Subsurface Characterization Results and Interpretation}

Results from the sediment sampling, physical property analysis, geologic log, geophysical logs, well development, and aquifer testing from each borehole are correlated to provide an interpretation of the hydrogeology at each borehole. This section includes a discussion of the criteria used to evaluate and interpret the data. The composite logs in Figures 4 and 5 illustrate the interpreted hydrogeology developed for each well.

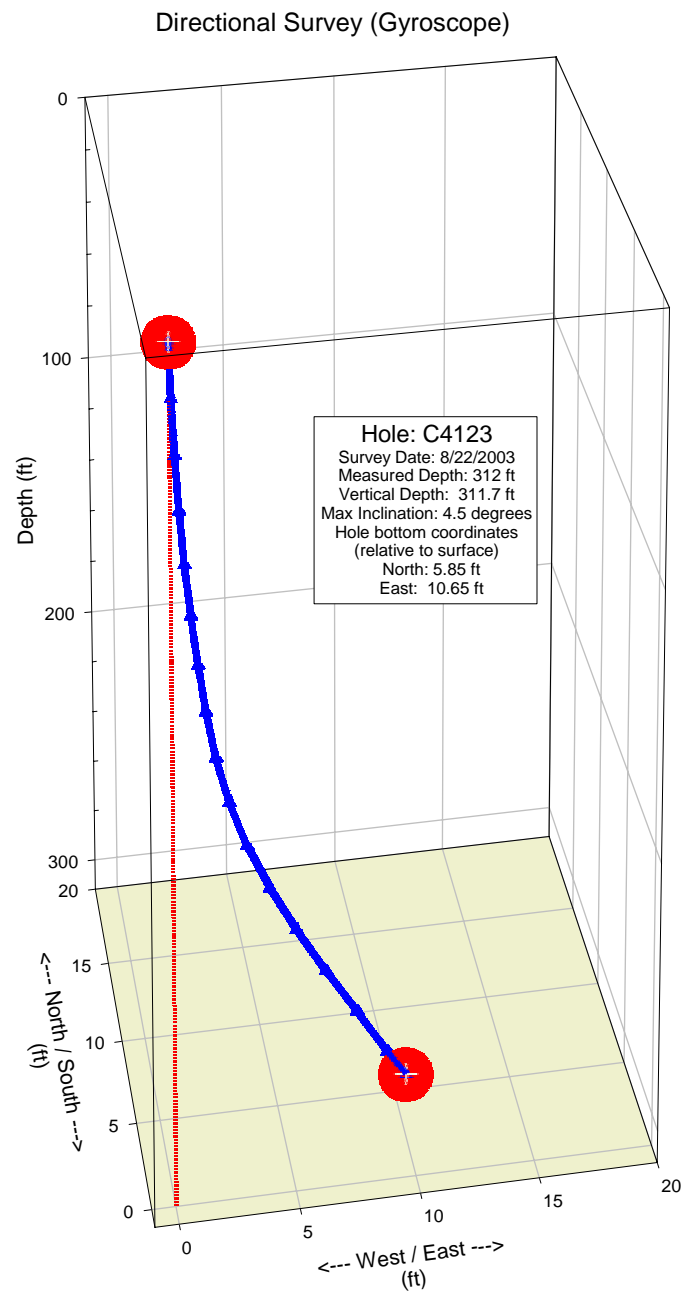

Figure 3. Vertical Profile and Bottom Hole Projections of Well 299-E24-22 


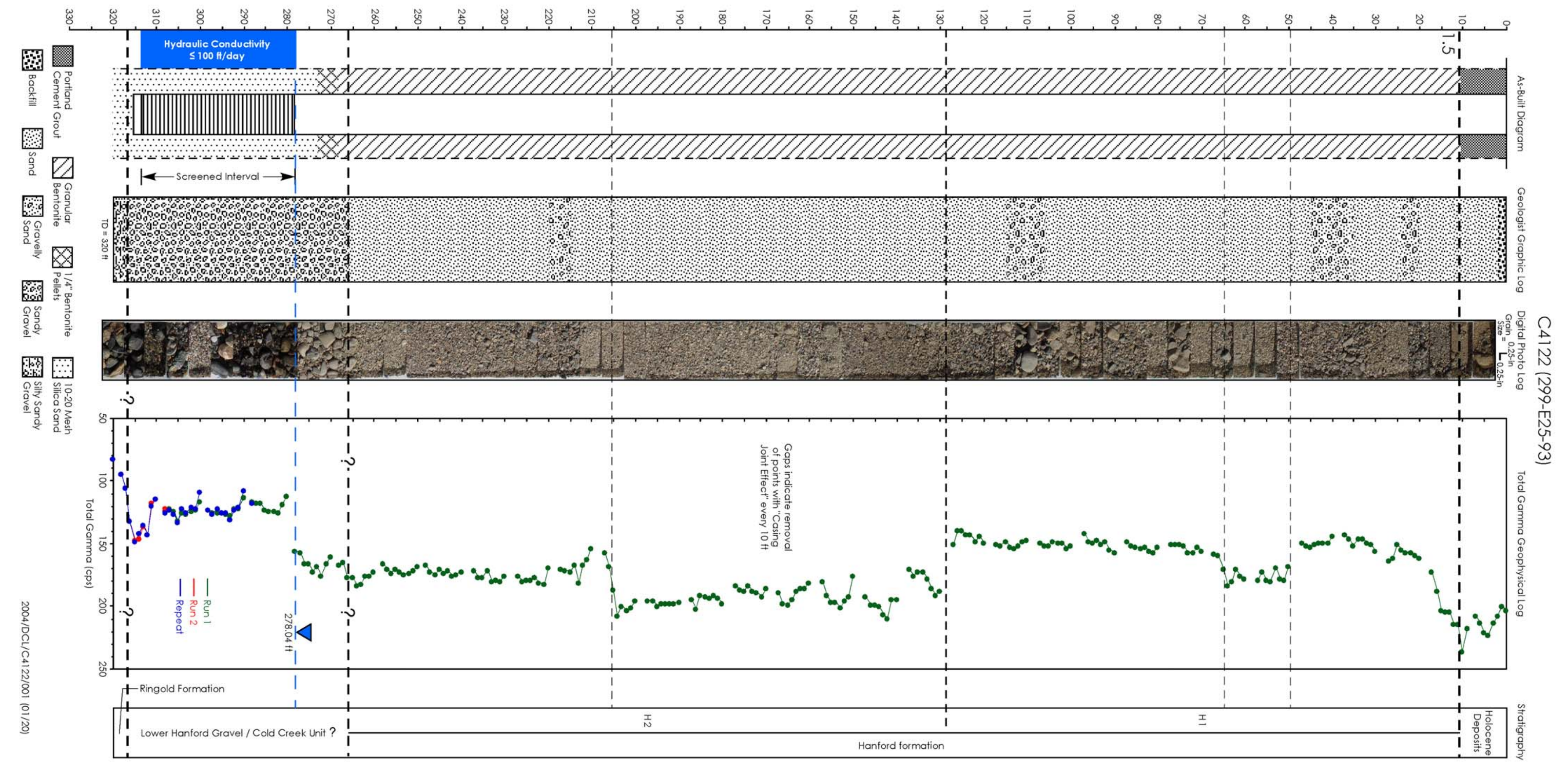

Figure 4. Hydrogeologic Interpretation for Well 299-E25-93 near Single-Shell Tank Farm WMA A-AX 
Depth (ti) Below Ground Surtace

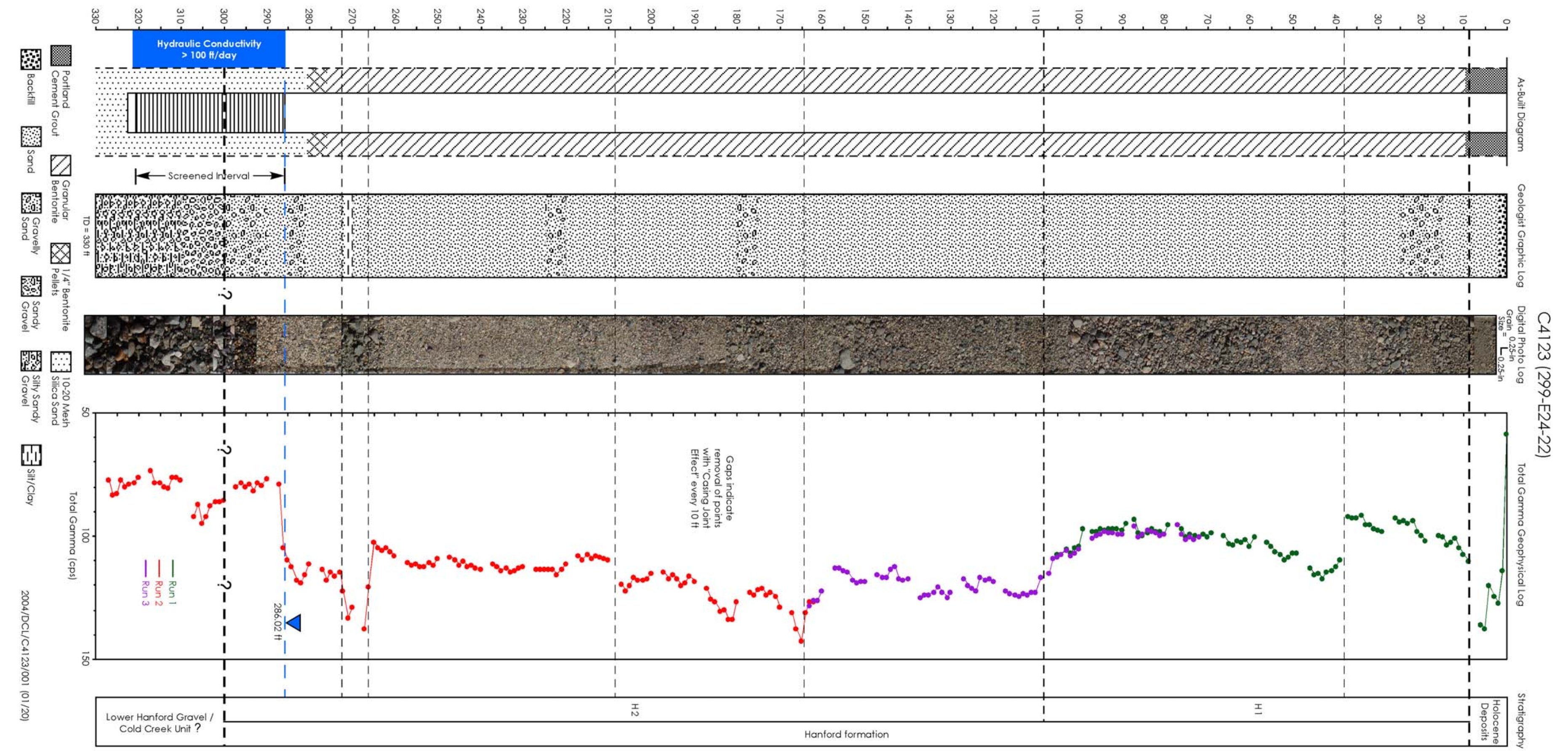

Figure 5. Hydrogeologic Interpretation for Well 299-E24-22 near Single-Shell Tank Farm WMA A-AX 


\subsection{Physical Properties}

There was no analysis for physical properties conducted on samples from these wells except sieve analysis of sediment samples (grab or split spoon) collected from the screen interval for particle size distribution. Particle size distribution results (sieve results) are provided in Appendix B.

Grab samples collected at 5-foot-depth intervals are described on the geologist's borehole log located in Appendix A. The wellsite geologist's graphic representation of the borehole logs for both wells are illustrated in composite logs (Figures 4 and 5). The sample quality and formation representativeness of the grab samples, and thus the borehole log descriptions, are limited due to the nature of the drilling. Drill rates were very fast ( $>250$ feet per day) and the airlifted cuttings return process, which causes gravity separation of sediments based on grain size and density, most likely mixed a lot of the sediment cuttings from different depth intervals before the cuttings reached the surface. When thin beds or sharp contacts were drilled, the returned sediments that were collected could not be easily evaluated or confidently correlated to their representative depth intervals.

The spectral gamma geophysical logs do indicate the presence of sharp contacts and/or thin bed intervals which can not always be differentiated in the returned cuttings. These changes are not documented in the geologic borehole log for these wells but evidence they exist can be seen in core data collected in a nearby well. Vadose-zone core recovered from well C4124 (299-E27-22) at single-shell tank WMA C provides evidence of these contacts and the thin, sharp lithologic changes that are seldom recognized when only evaluating drill cuttings returns from the Becker-Hammer drilling method.

\subsection{Sediment Digital Photographic Log}

A digital photographic log is included in each composite log for the wells (Figures 4 and 5). Grab samples from the cuttings return line (cyclone) were collected for lithologic descriptions, documented in the borehole log in Appendix A archives, and for digital photography of the sediments. These photographic log presentations, compiled from 1-inch chip tray samples collected at 5-foot-depth intervals, provide a qualitative visual tool that reveals changes in major lithologic intervals (i.e., grain size, color, and relative moisture). The digital photographic logs provide a means to illustrate subsurface lithologic and related hydrogeologic features. The interpretative value of these logs is also limited by the sample collection technique and sample container site.

\subsection{Geophysical Logging}

Cesium-137 was the only manmade radionuclide detected in both wells. This contaminant is mainly at the surface but there are a few sporadic detects at the minimum detectable level throughout the boreholes. Appendix C provides more details about the cesium detected in the boreholes.

For well 299-E25-93, geophysical log plots of the naturally occurring gamma emitting radionuclides (potassium, uranium, and thorium) indicate there are several distinct activity changes (inflection points) at depths of $~ 50,65,130,205$, and 279 feet bgs. These major changes correlate to lithologic features (i.e., contacts and/or thin contrasting lithologic intervals) and the water table (Figure 4). The inflections at 
50, 65, 130 and 205 feet bgs probably correspond to distinct changes in lithology (i.e., grain size, clast mineralogy, or both). As discussed in the section above, these changes are not documented in the geologic borehole log for this well but evidence they exist can be seen in core data collected in a nearby well.

For well 299-E24-22, geophysical log plots of naturally occurring radionuclides indicate there are several distinct activity changes (inflection points) at depths of $~ 38,108,165,208,267,272$, and 286 feet bgs. The inflections at 38, 108, 165, and 208 bgs probably correspond to unrecognized changes in lithology similar to those discussed in the previous sections. The inflections at 267 and 272 feet bgs and high gamma peaks ( $\sim 268$ and 271 feet bgs) correspond to a $\sim 5$ foot thick silt/clay interval that is recognized in the borehole and as clay clumps in the digital photographic logs (Figure 5). The water table is indicated at 286 feet bgs.

No attempt has been made to correlate specific units of facies between these two wells, although evaluation of the logs does suggest some continuity may exist.

\subsection{Aquifer Tests}

Slug testing was performed in both wells following construction and development. The slug tests are performed to provide semi-quantitative calculation of hydraulic conductivity in the unconfined aquifer (i.e., the screen interval). The slug testing results provide an objective method to evaluate the hydraulic properties of the formation and support interpretation of the hydrogeology of the aquifer system.

Highly permeable conditions are indicated from well screen development drawdown data collected during constant rate pumping in both wells. Drawdowns were less than 0.11 feet (22.5 gallons-perminute pump rate) and 0.16 feet (25.5 gallons-per-minute pump rate) in wells 299-E24-22 and 299-E2593, respectively. During slug testing, both wells exhibited highly permeable screened test intervals with test recovery within 10 seconds. Well 299-E24-22 exhibits an oscillatory, underdamped slug test response, while well 299-E25-93 displays a rapid, exponential decay (overdamped) test response. An oscillatory response indicates a higher permeability test interval (all other test parameters being similar, e.g., well-screen length). Preliminary average hydraulic conductivity values for the two wells are: well 299-E24-22 > 100 feet per day and well 299-E25-93 $\leq 100$ feet per day. Quantitative analysis results for these two well sites will be documented in a subsequent PNNL technical report that presents hydrologic test results for slug tests conducted during fiscal year 2003.

\subsection{Composite Logs}

Composite logs have been assembled for each well using the well as-builts, aquifer testing results, the geologic graphic log description of the sediments, the digital photographic log, and the geophysical logs. Stratigraphic interpretation contacts and key lithologic changes are identified where possible. The composite logs for new wells 299-E25-93 and 299-E24-22 are illustrated in Figures 4 and 5, respectively. These interpretations are also consistent with Woods et al. (2003) and Williams et al. (2000).

The Hanford formation comprises most of the thick vadose zone in both wells, composed mostly of sand to silty sandy gravel. There are several distinct contacts and thin fine grain lithologic intervals (e.g., 
silt or soil horizons) within the Hanford formation, implied by the inflections on the geophysical logs. The most significant inflections are dashed on the composite log to imply a contact.

The uppermost unconfined aquifer is composed mostly of uncemented, loose, gravel to silty sandy gravel and appears characteristic of the more permeable lower Hanford formation and/or the Cold Creek unit (formerly called “reworked Ringold Formation sediments” or the "Pre-Missoula Gravel”). The contact between the lower Hanford formation and the Cold Creek unit is gradational and not easy to distinguish. The lower Hanford formation and/or Cold Creek unit upper contact is approximately located at 266 and 300 feet bgs in wells 299-E25-93 and 299-E24-22, respectively (Figures 4 and 5). Criteria for designating the Cold Creek unit sediments include dominantly gravel deposition, samples composed of less than $50 \%$ basalt, and hydraulic conductivity values (> 55 feet per day) greater than published results for known Ringold Formation sediments. ${ }^{(b)}$ However, distinguishing this unit based on hydraulic conductivity valves from lower Hanford formation gravel is not possible in this area.

In well 299-E25-93, the very bottom 3 feet from 317 to $320 \mathrm{ft}$ bgs (total depth) comprises a portion of the Ringold Formation Unit 9. This unit is characterized by silty sandy gravel that is less than $25 \%$ basalt, has moderate cementation, contains iron staining, micaceous material, and is described in daily drilling logs as difficult slower drilling. The interpretation of the lower Ringold Formation Unit 9 at the bottom of this well is consistent with interpretations described in Williams et al. 2000.

\subsection{References}

Atomic Energy Act of 1554 (AEA). 1954. As amended, Ch. 1073, 68 Stat. 919, 42 USC 2011 et seq.

Byrnes ME and BA Williams. 2003. Data Quality Objectives Summary Report for Establishing a RCRA/CERCLA/AEA Integrated 200 West and 200 East Area Groundwater Monitoring Network, CP-15329, Rev. 0. Prepared by Fluor Hanford, Inc. for the U.S. Department of Energy, Richland, Washington.

Comprehensive Environmental Response, Compensation, and Liability Act (CERCLA). 1980. Public Law 96-150, as amended, 94 Stat. 2767, 42 USC 9601 et seq.

DOE. 2002. Standardized Stratigraphic Nomenclature for the Post-Ringold-Formation Sediments Within the Central Pasco Basin, DOE/RL-2002-39, Rev. 0, U.S. Department of Energy, Richland, Washington.

Ecology - Washington State Department of Ecology, U.S. Environmental Protection Agency, and U.S. Department of Energy. 1998. Hanford Federal Facility Agreement and Consent Order. Document No. 89-10, Rev. 5 (The Tri-Party Agreement), Olympia, Washington.

NAD83 (91) North American Datum of 1983 (1991 adjustment).

(b) Letter report from FA Spane to VG Johnson (Pacific Northwest National Laboratory, Richland, Washington), "Summary of Hydraulic Conductivity Estimates Obtained From Recent Hydrologic Characterization Tests Conducted in the WMA S-SX,” 2002. 
Narbutovskih SM and DG Horton. 2001. RCRA Groundwater Monitoring Plan for Single-Shell Tank Waste Management Area A-AX at the Hanford Site. PNNL-13023, Pacific Northwest National Laboratory, Richland, Washington.

NAVD88 North American Vertical Datum of 1988.

Resource Conservation and Recovery Act (RCRA). 1976. Public Law 94-580, as amended, 90 Stat. 2795, 42 USC 6901 et seq.

Washington Administrative Code (WAC). "Minimum Standards for Construction and Maintenance of Wells.” WAC 173-160, Washington Administrative Code, Olympia, Washington.

Williams BA. 2003. Description of Work for Drilling RCRA Groundwater Monitoring Wells During Calendar Year 2003. PNNL-SA-38611, Pacific Northwest National Laboratory, Richland, Washington.

Williams BA, BN Bjornstad, R Schalla, and WD Webber. 2000. Revised Hydrogeology for the Suprabasalt Aquifer System, 200-East Area and Vicinity, Hanford Site, Washington. PNNL-12261, Pacific Northwest National Laboratory, Richland, Washington.

Wood MI, TE Jones, BN Bjornstad, DG Horton, SM Narbutovskih, and R Schalla. 2003. Subsurface Conditions Description of the C and A-AX Waste Management Area. RPP-14430, CH2M Hill Hanford Group, Inc., Richland, Washington. 


\section{Appendix A}

\section{Well Construction and Completion Documentation}




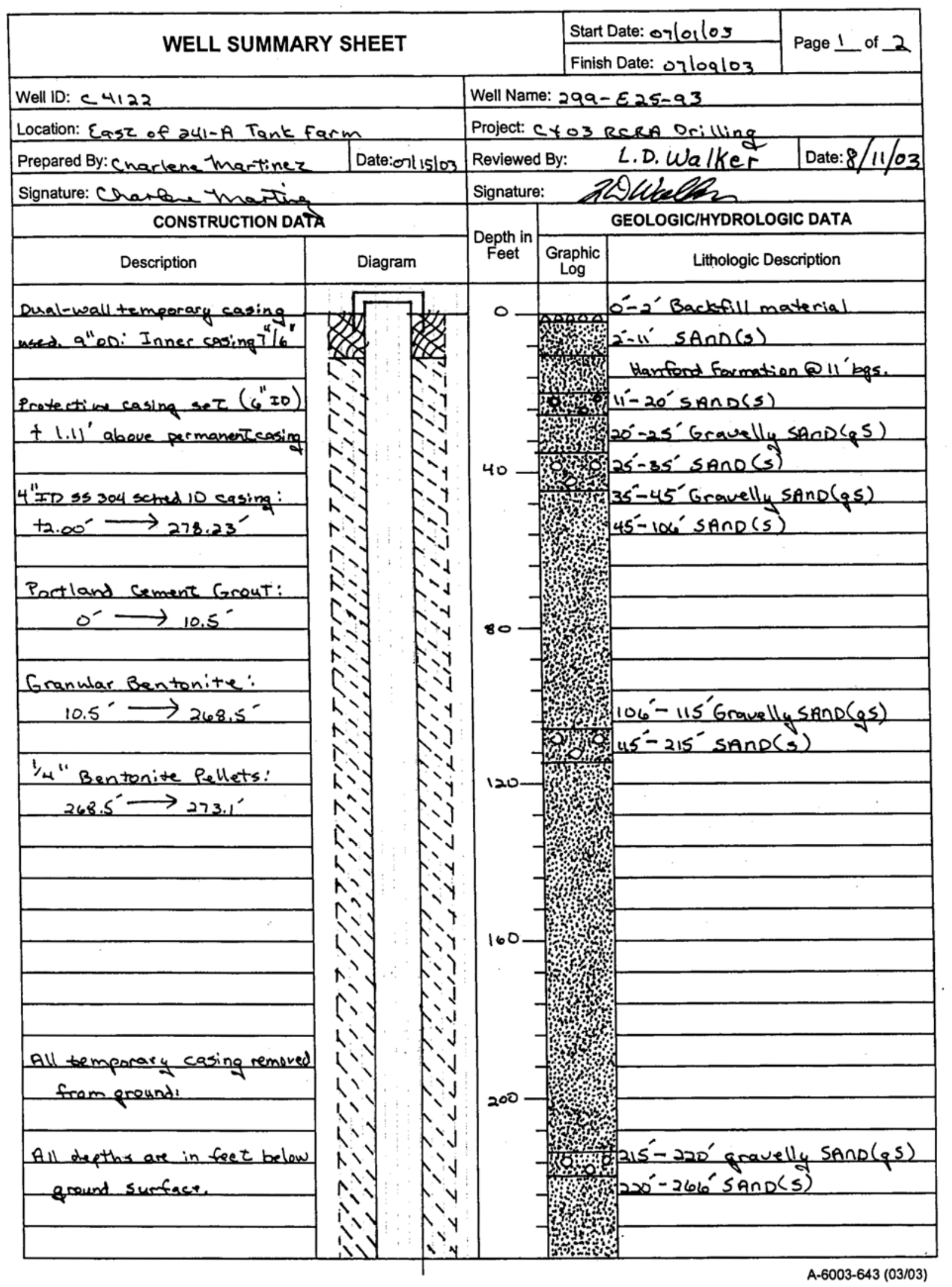




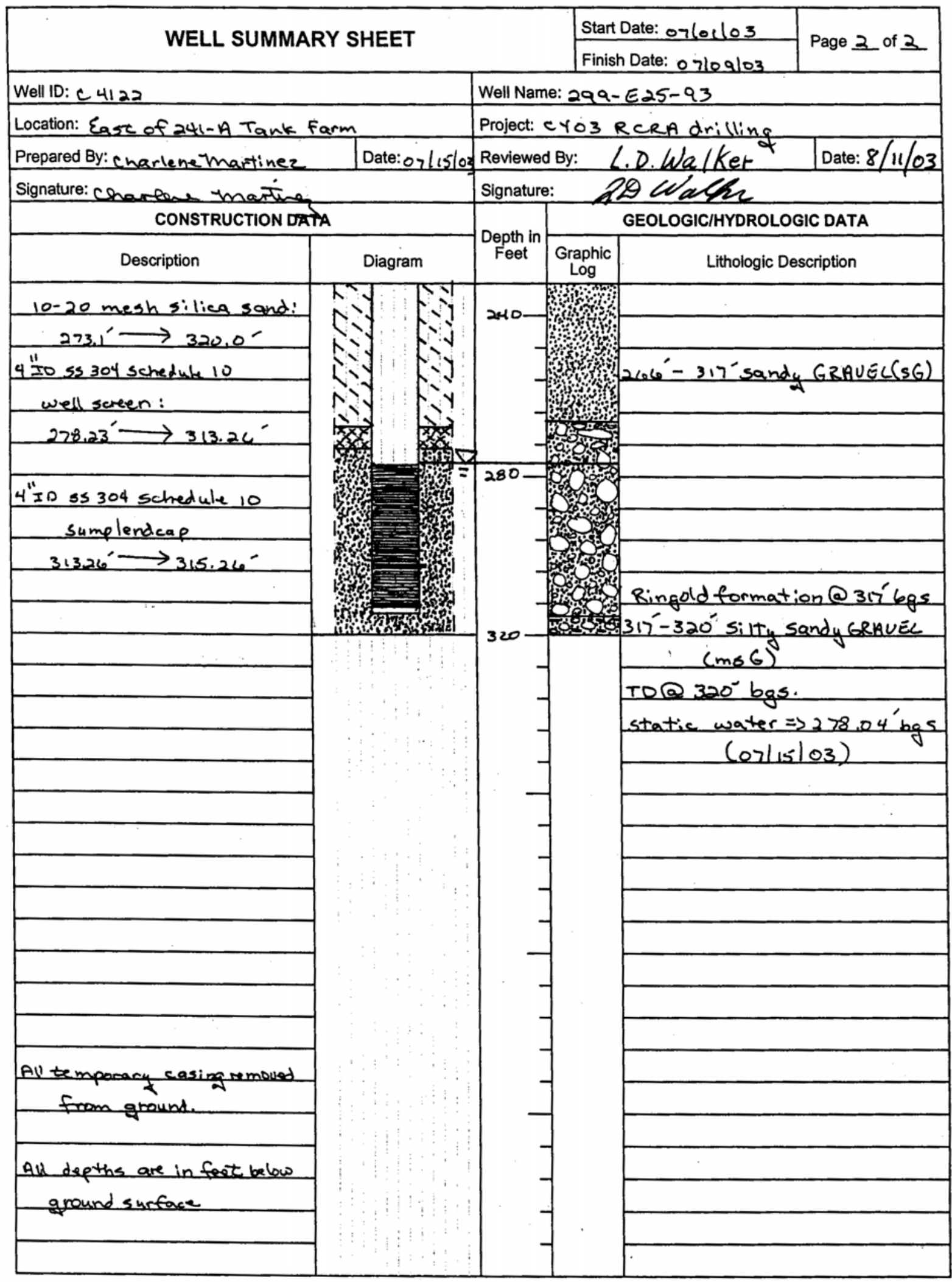

A-6003-643 (03/03) 


\section{WELL CONSTRUCTION SUMMARY REPORT}

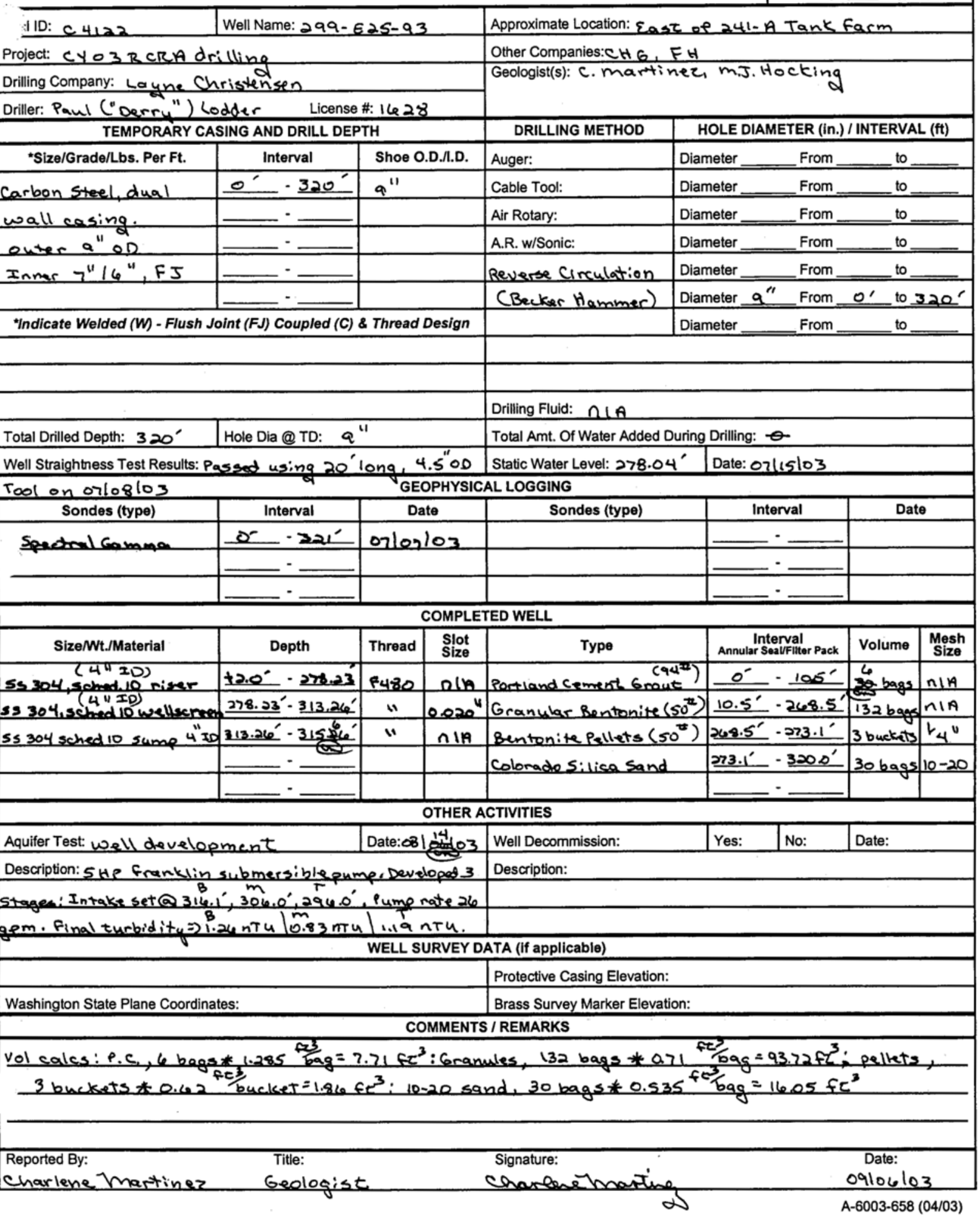




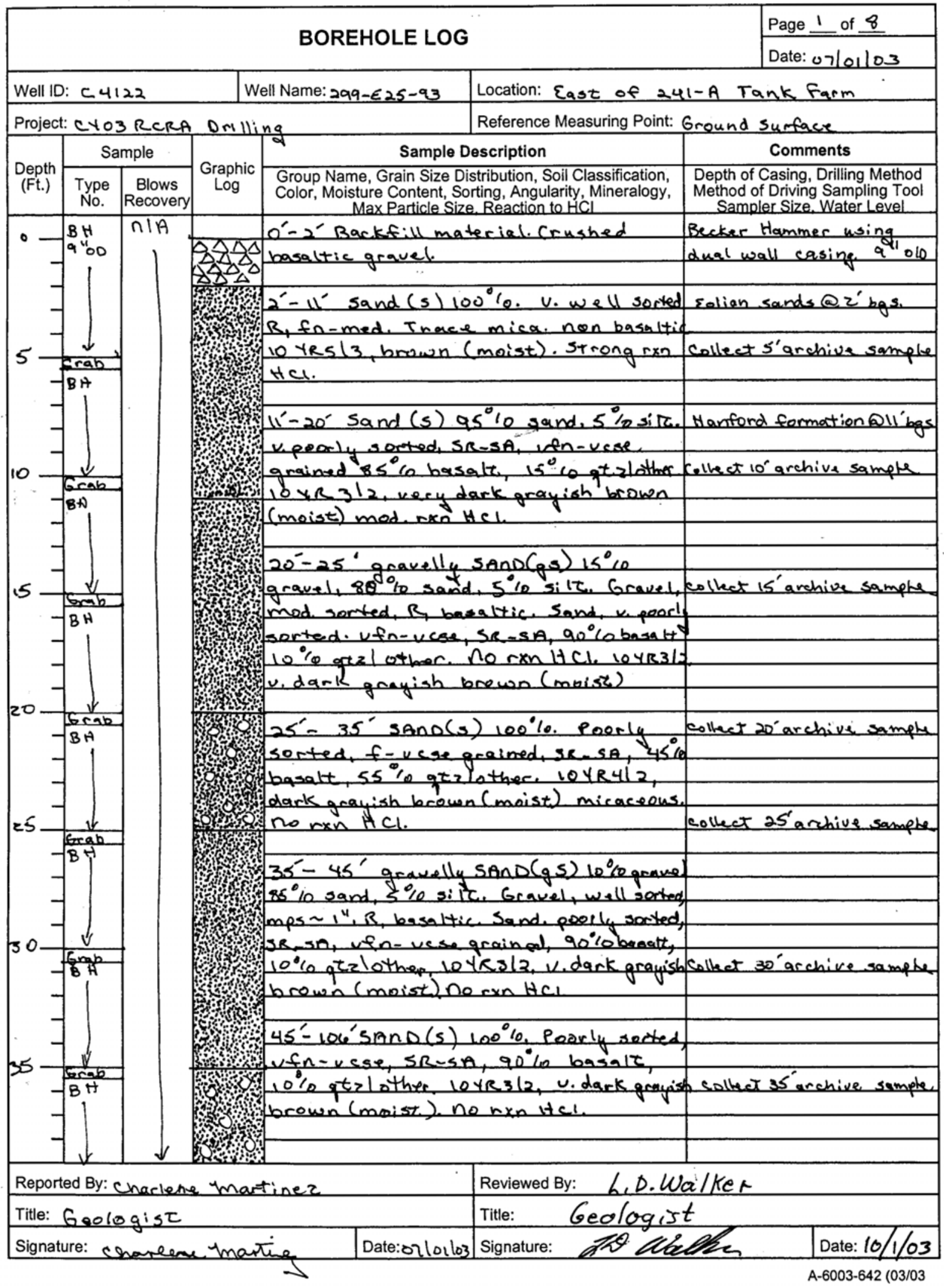




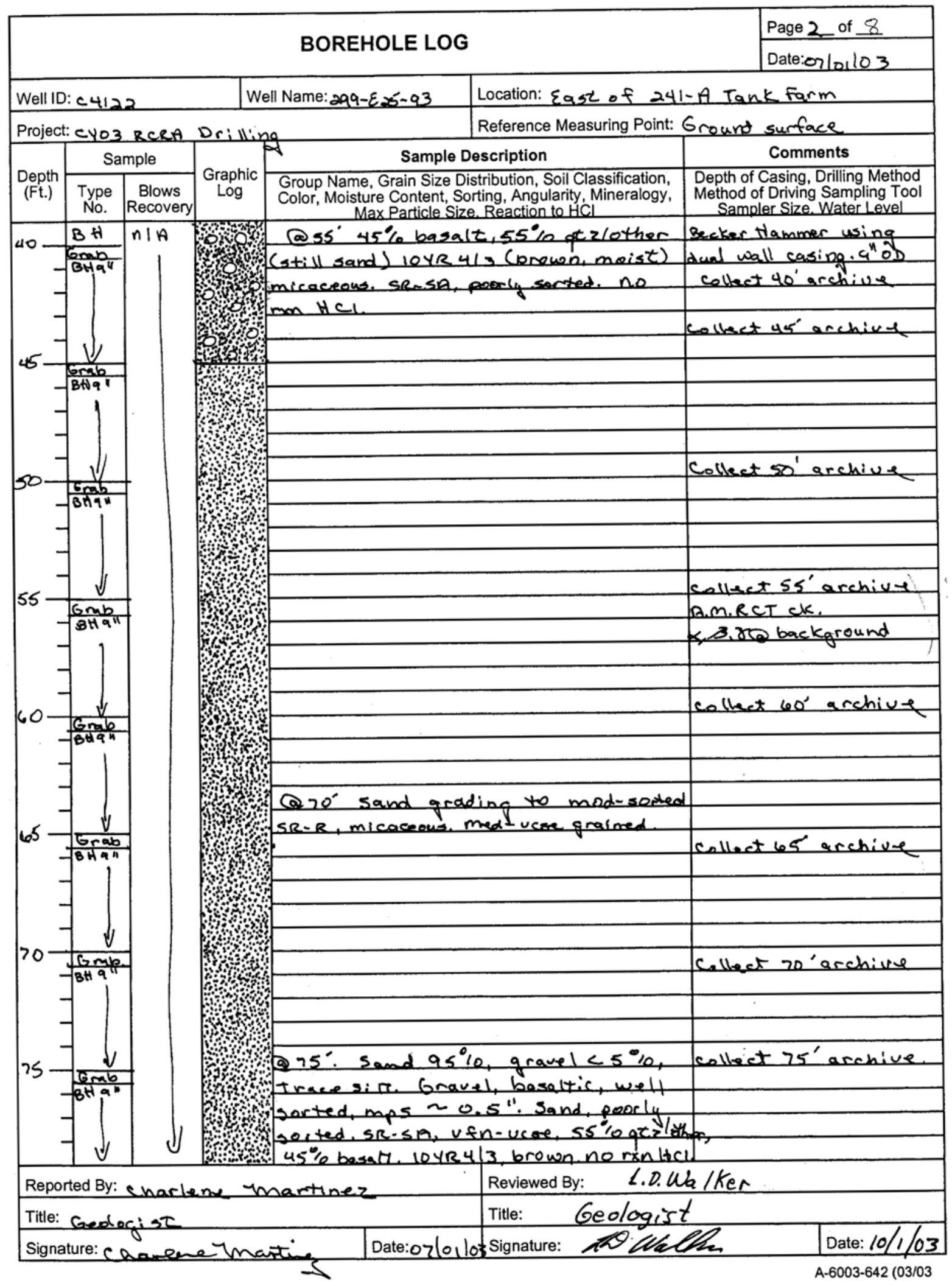




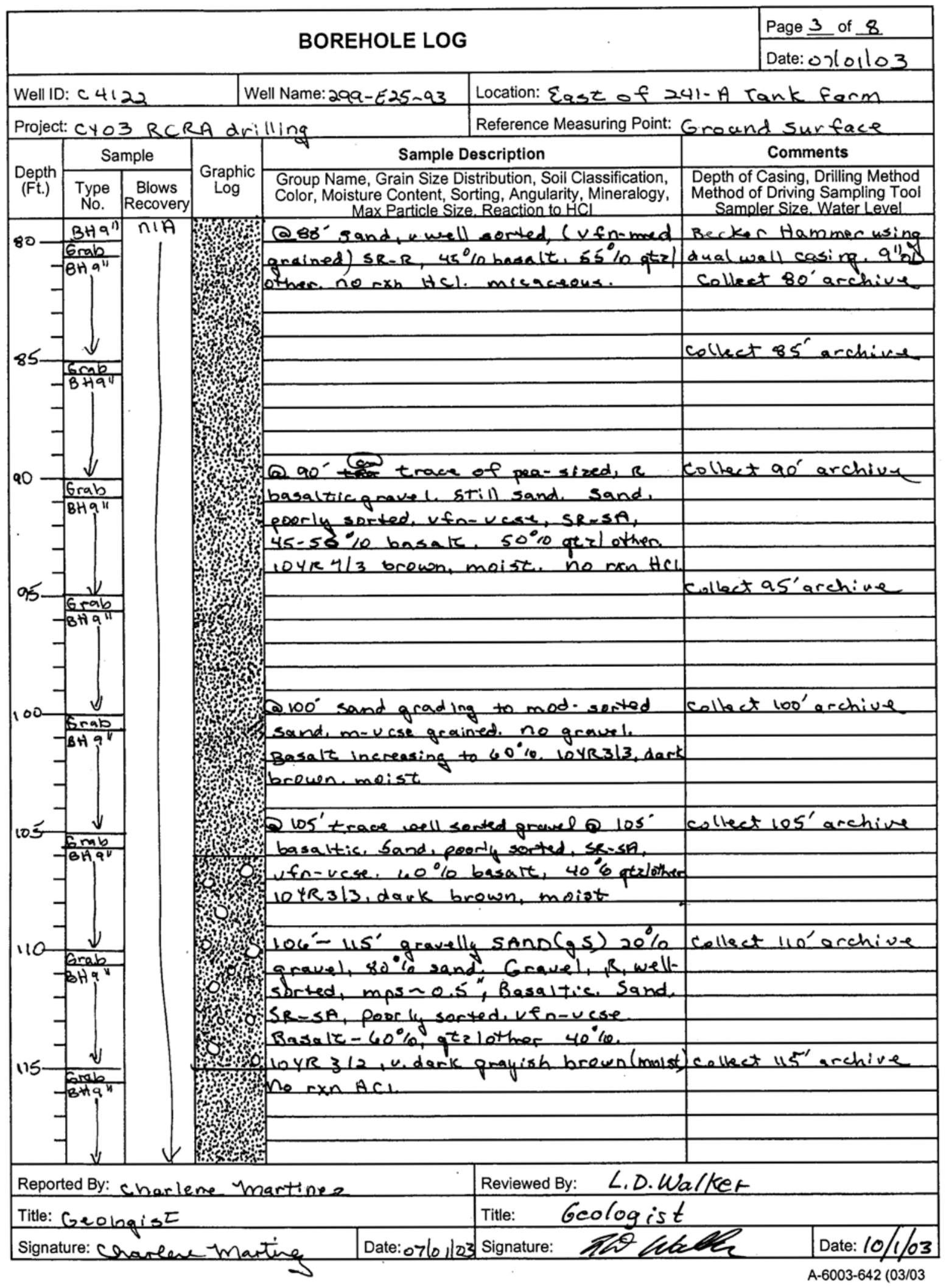




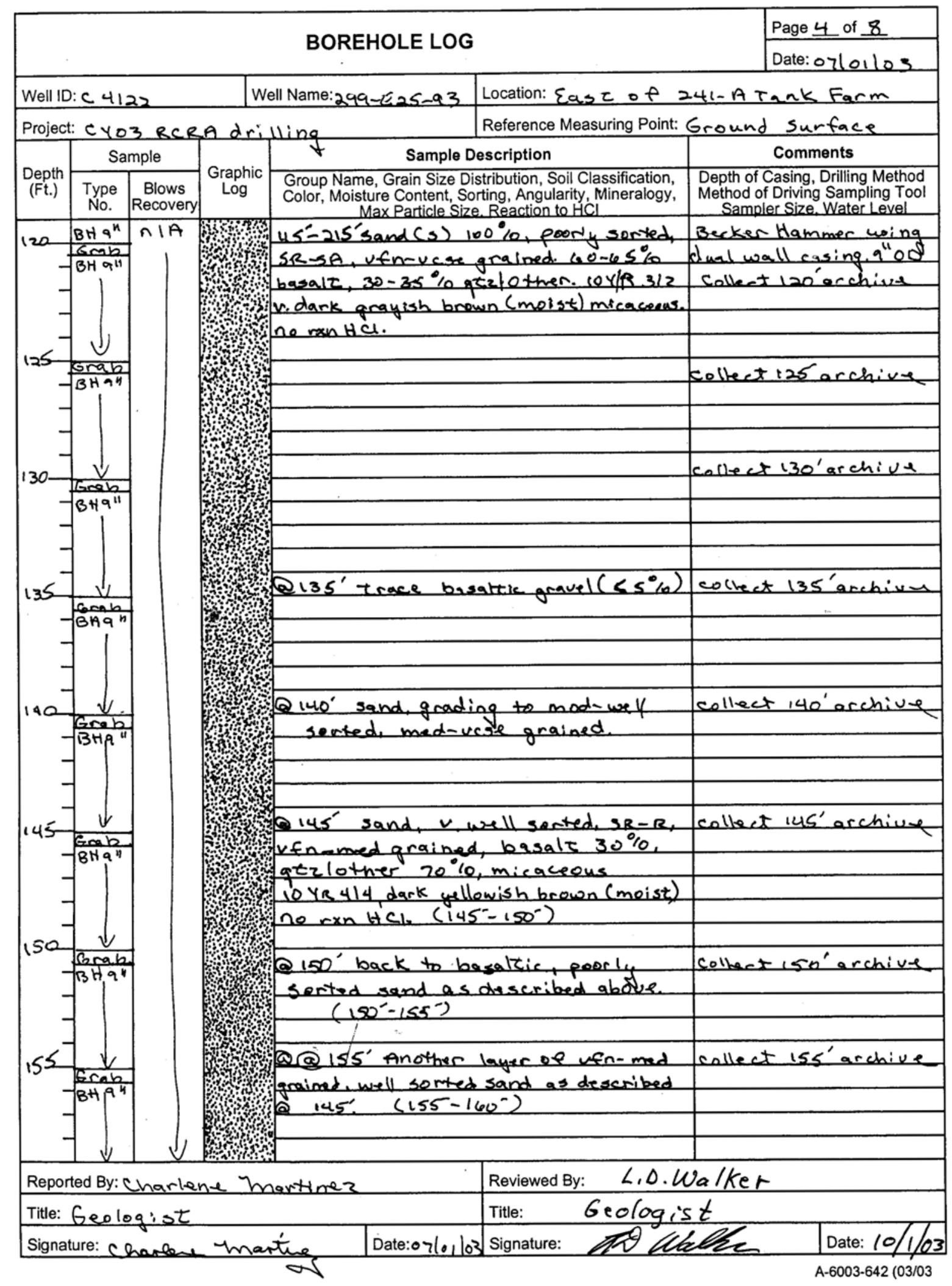




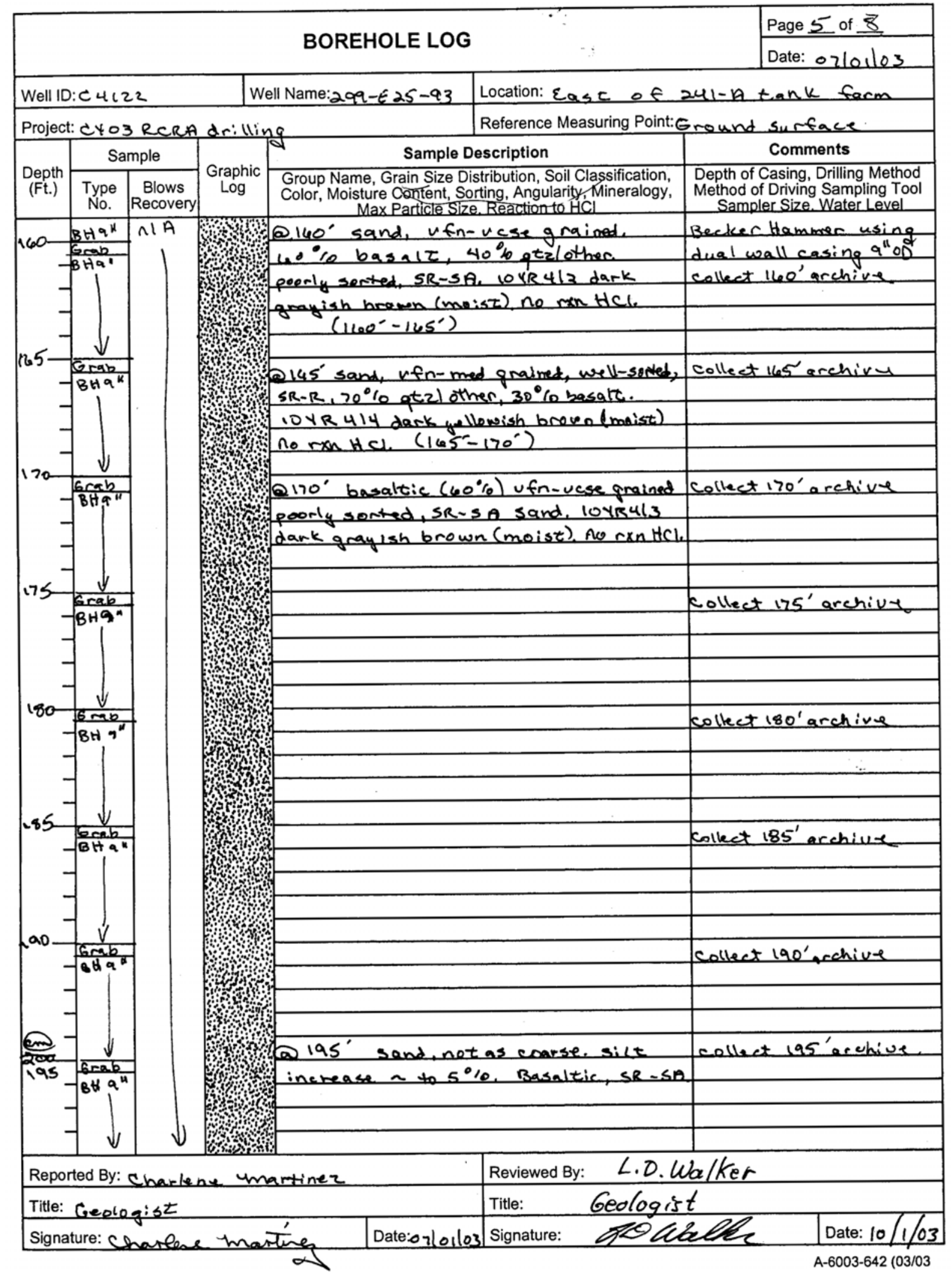




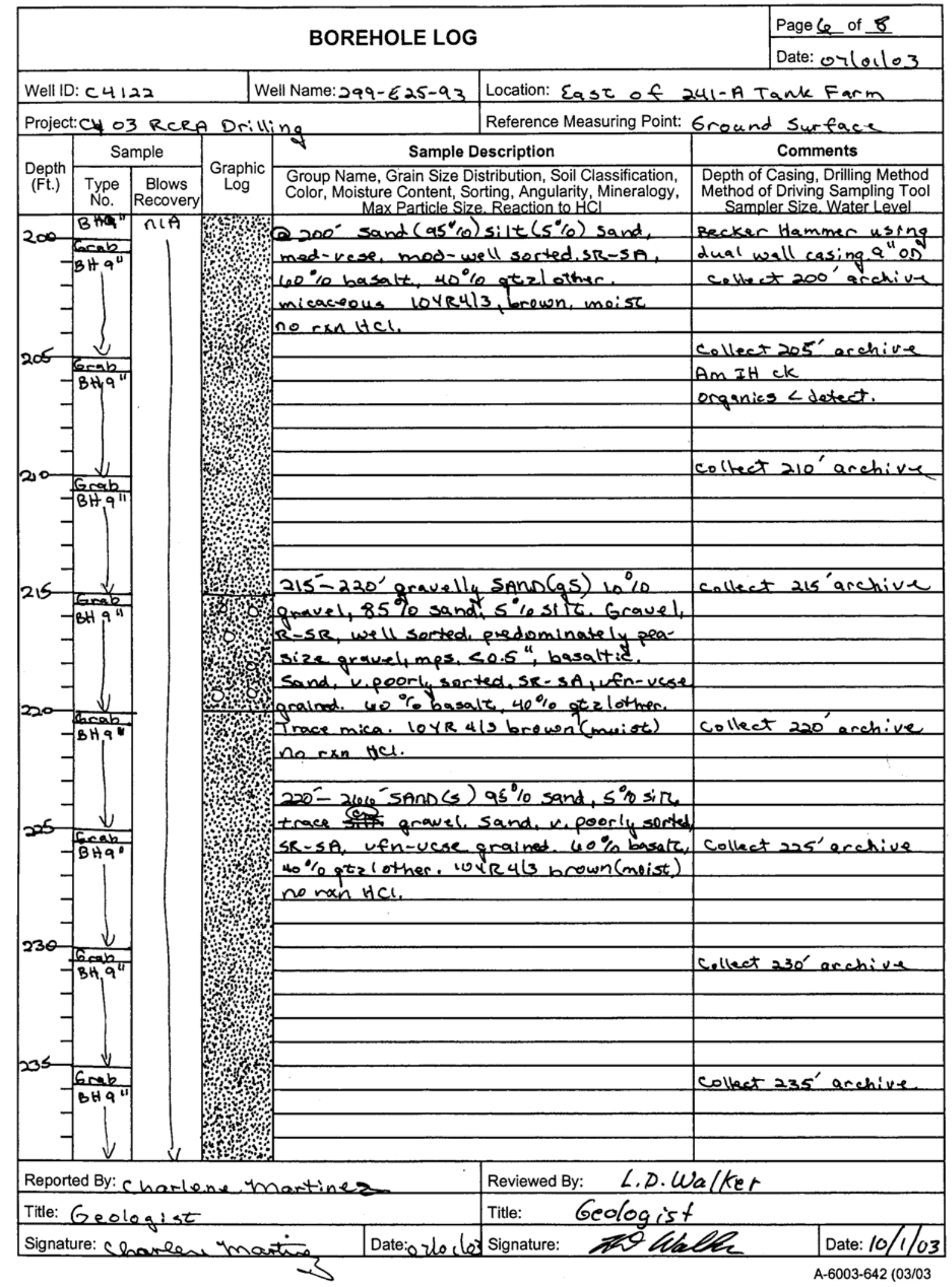




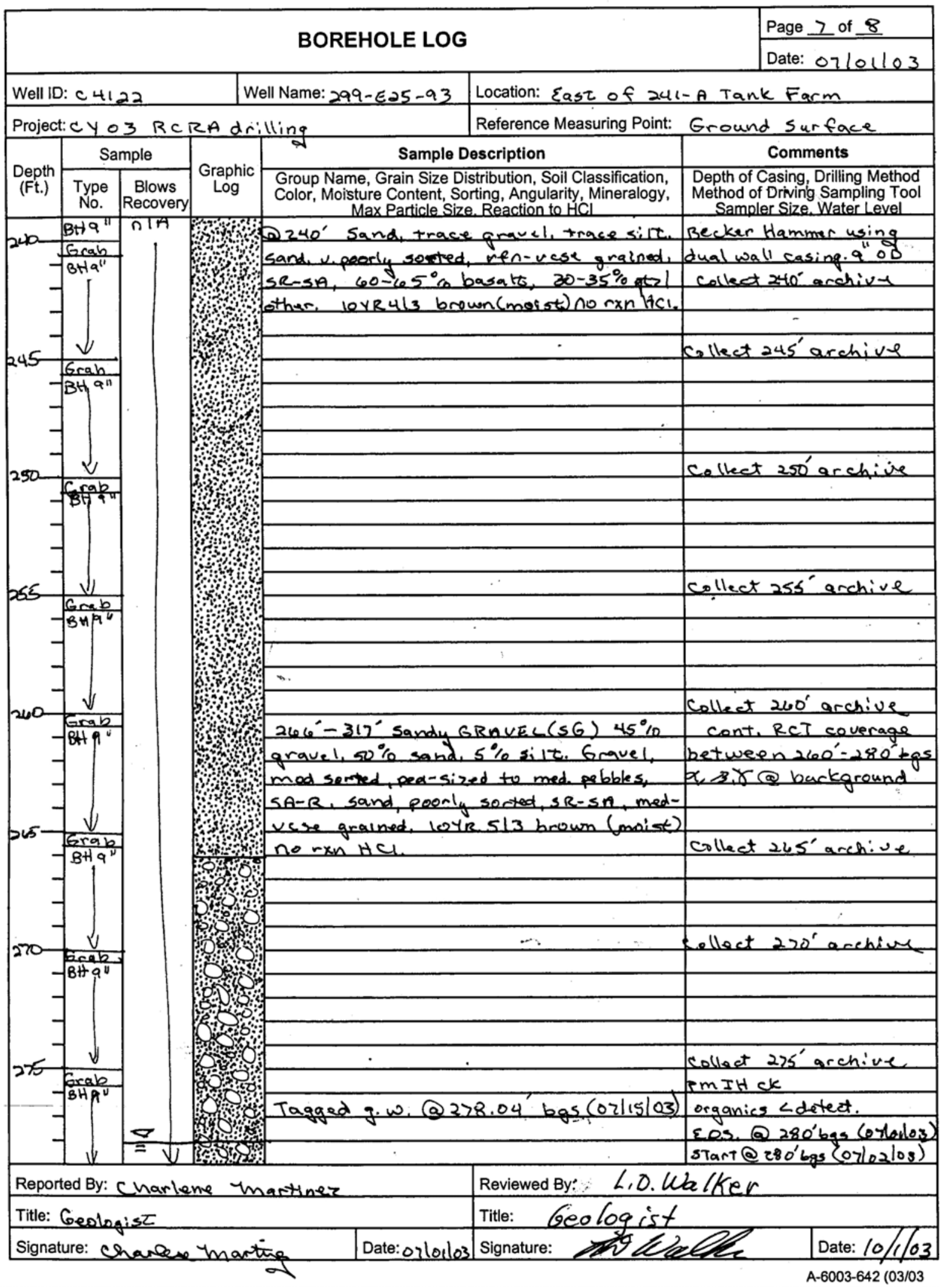




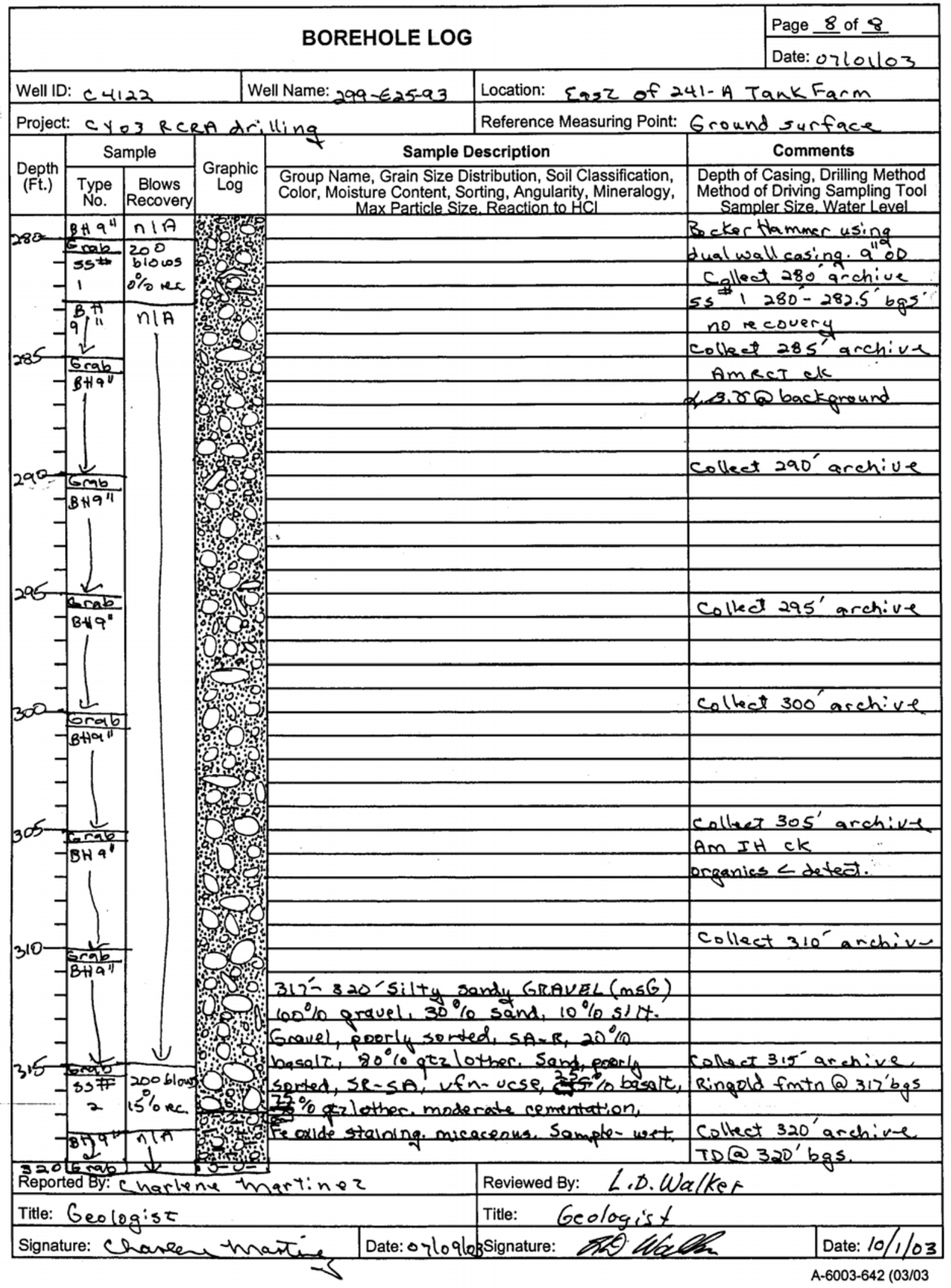




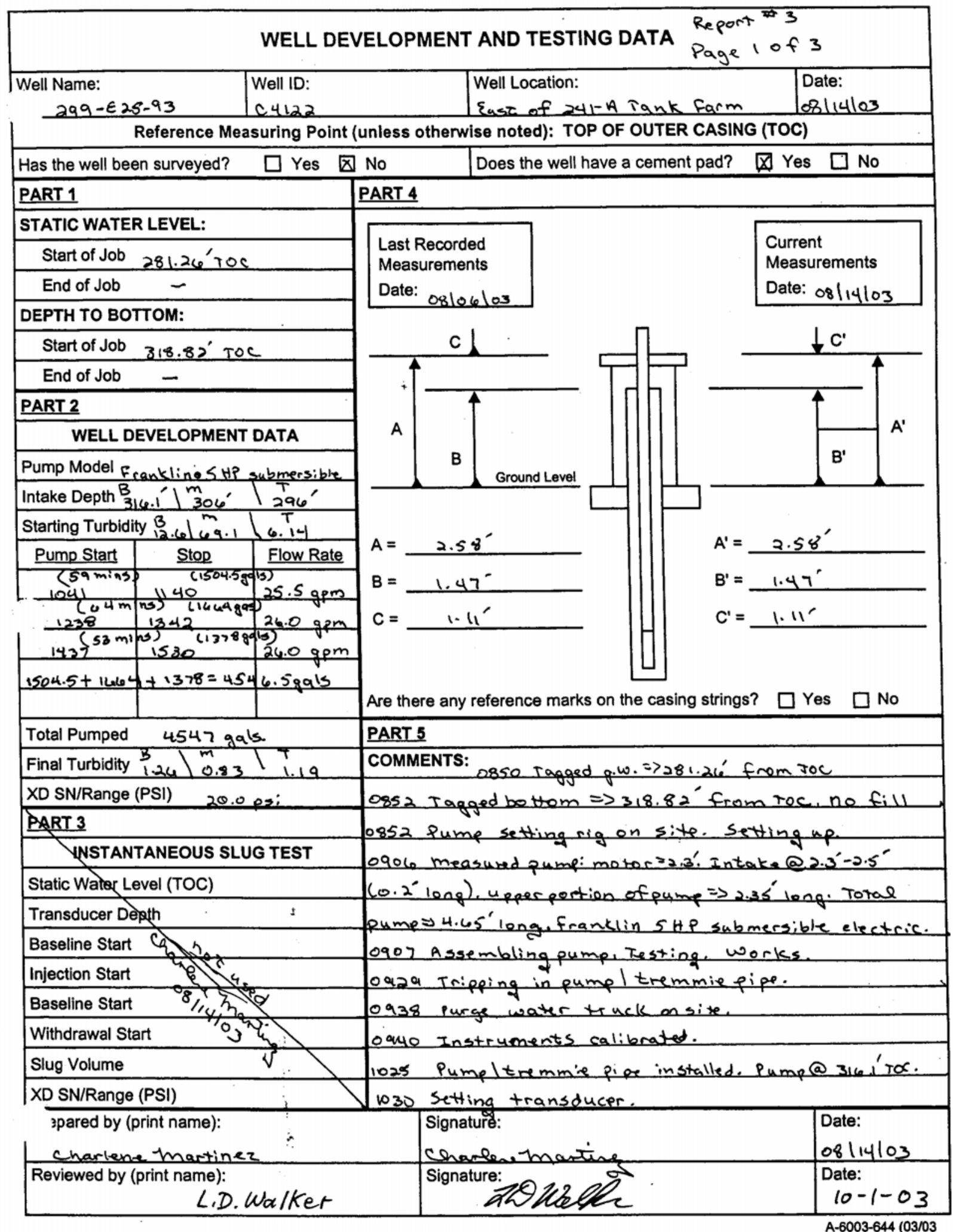




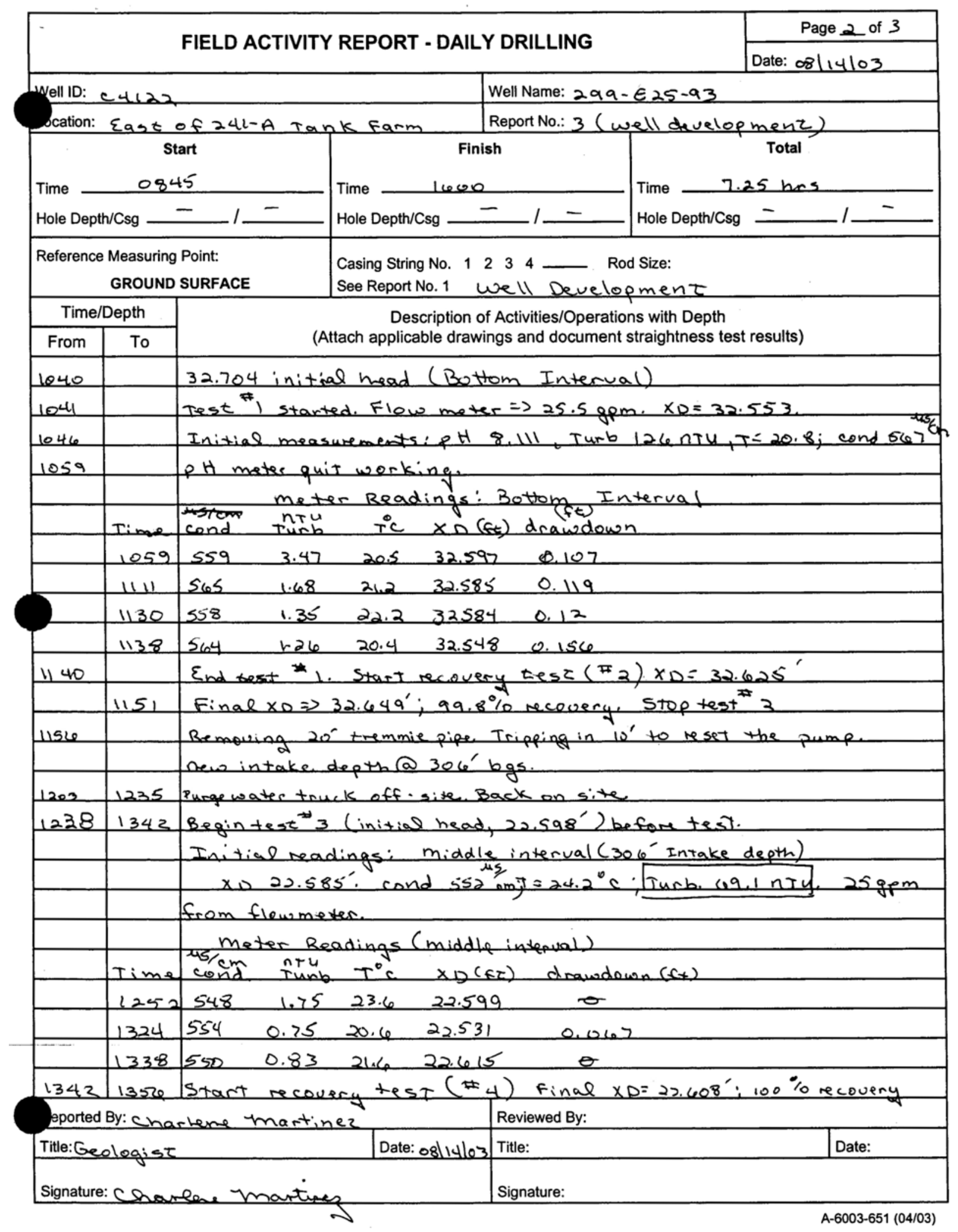




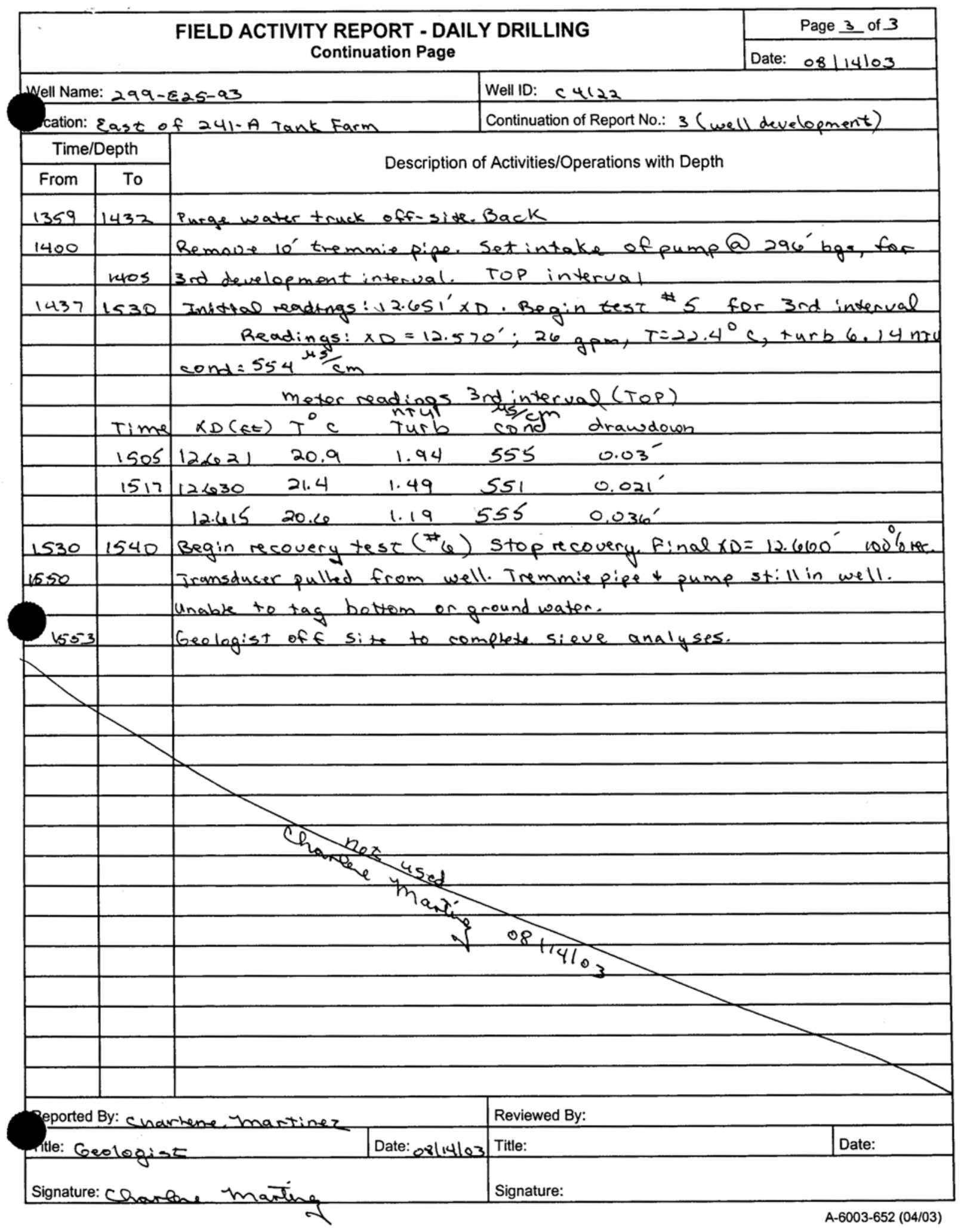




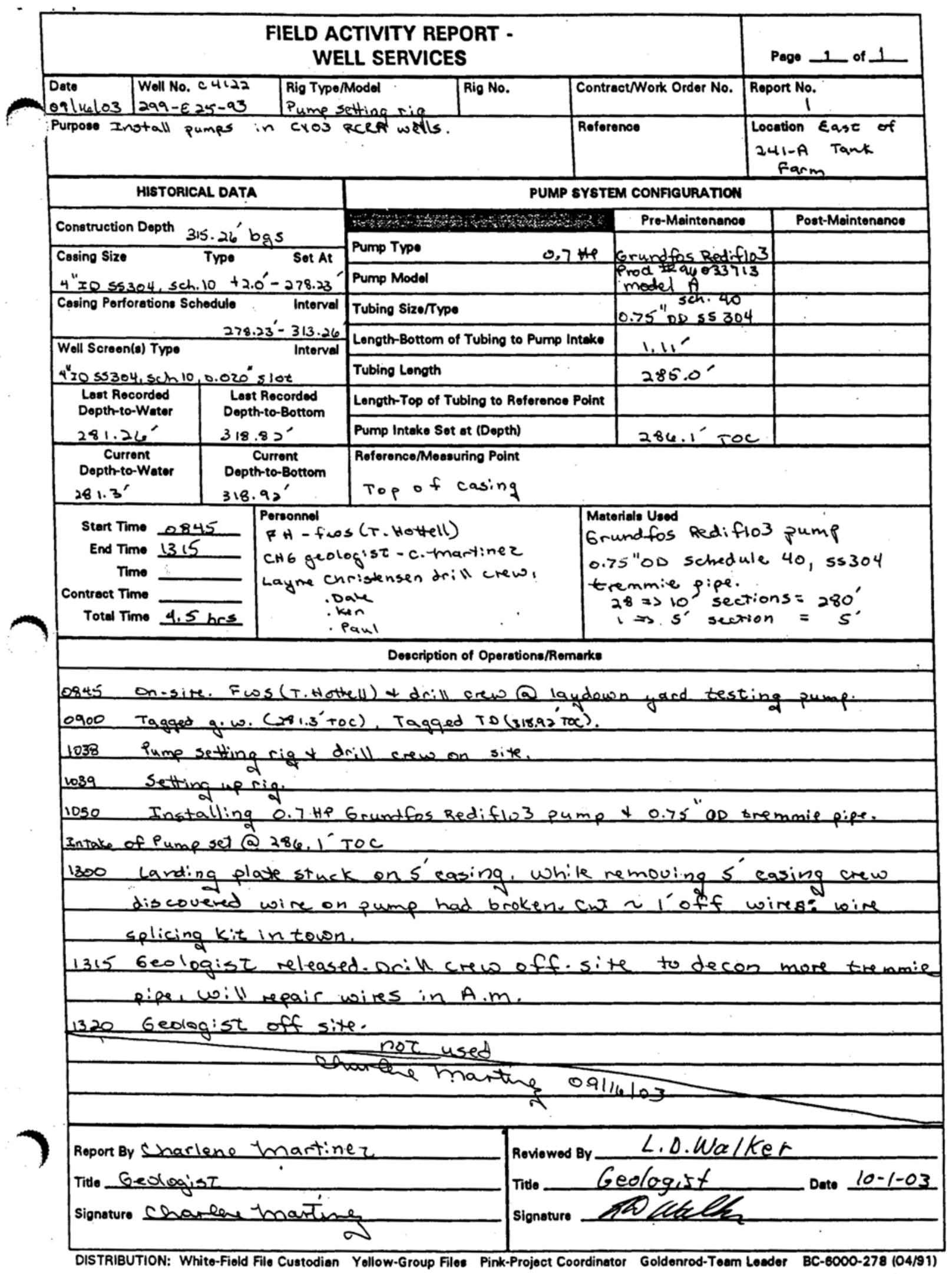




\section{WELL SURVEY DATA REPORT}

\begin{tabular}{|c|c|c|c|c|c|}
\hline \multicolumn{3}{|l|}{ Project: } & \multicolumn{3}{|c|}{$\begin{array}{ll}\text { Prepared By: } & \text { Neil P. Fastabend } \\
\text { Company: } & \text { Fluor Federal Services }\end{array}$} \\
\hline \multicolumn{3}{|c|}{ Date Requested: $9 / 29 / 03$} & \multicolumn{3}{|c|}{ Requestor: Chris S. Wright (FH) } \\
\hline \multicolumn{3}{|c|}{ Date of Survey: $10 / 31 / 03$} & \multicolumn{3}{|c|}{$\begin{array}{ll}\text { Surveyor: } & \text { Fluor Federal Services } \\
& \text { Survey Dept. }\end{array}$} \\
\hline \multicolumn{3}{|c|}{ ERC Point of Contact: } & \multicolumn{3}{|c|}{$\begin{array}{r}\text { Survey Co. Point of Contact: } \\
\text { Grant F. Brazil, P.L.S. }\end{array}$} \\
\hline \multirow{4}{*}{\multicolumn{3}{|c|}{$\begin{array}{l}\text { Description of Work: } \\
\text { Civil Survey of Groundwater Monitoring } \\
\text { Well C4122 (299-E25-93). }\end{array}$}} & \multicolumn{3}{|c|}{ Horizontal Datum: NAD83(91) } \\
\hline & & & \multicolumn{3}{|c|}{ Vertical Datum: NAVD88 } \\
\hline & & & \multicolumn{3}{|c|}{ Units: $\quad$ Meters } \\
\hline & & & \multicolumn{3}{|c|}{ Hanford Area Designation: $200 \mathrm{E}$} \\
\hline \multicolumn{6}{|c|}{ Coordinate System: Washington State Plane Coordinates (South Zone) } \\
\hline \multicolumn{6}{|c|}{$\begin{array}{l}\text { Horizontal Control Monuments: } \\
\qquad 2 \mathrm{E}-127 \text { (FFS) and } 2 E-134 \text { (FFS) }\end{array}$} \\
\hline \multicolumn{6}{|c|}{$\begin{array}{l}\text { Vertical Control Monuments: } \\
\qquad 2 \mathrm{E}-18 \text { (FFS) and 2E-38 (FFS) }\end{array}$} \\
\hline Well ID & Well Name & Eastin & Northing & Elevation & \\
\hline \multirow[t]{4}{*}{ C4122 } & 299-E25-93 & 575471. & 136022.09 & & Center of Casing \\
\hline & & & & 208.040 & $\begin{array}{l}\text { Top Casing, } \\
\text { N. Edge }\end{array}$ \\
\hline & & & & 207.265 & Brass Survey Marker \\
\hline & & & & 208.046 & $\begin{array}{l}\text { Top Pump Base- } \\
\text { plate. N. Edqe }\end{array}$ \\
\hline \multicolumn{6}{|l|}{ Notes: } \\
\hline \multicolumn{6}{|c|}{$\begin{array}{l}\text { Surveyor Statement: } \\
\text { l, Grant F. Brazil, a Professional Land Surveyor registered } \\
\text { in the State of Washington (Registration No. 22326), hereby } \\
\text { certify that this report is based on a field survey performed in } \\
\text { October, } 2003 \text { under my direct supervision, and that the data } \\
\text { contained here is true and correct. }\end{array}$} \\
\hline
\end{tabular}

Original to:

Distribution by DIS: 


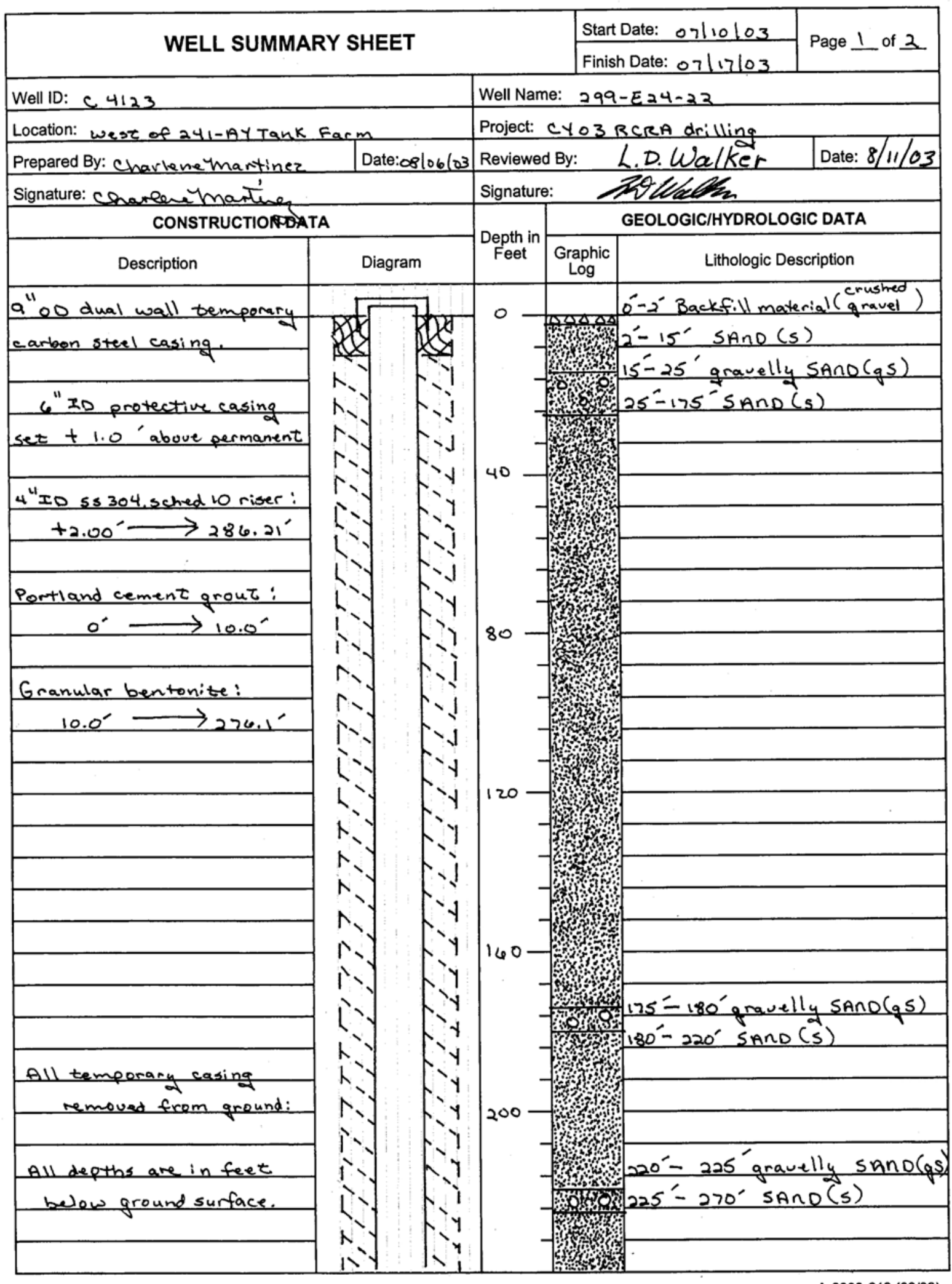

A-6003-643 (03/03) 


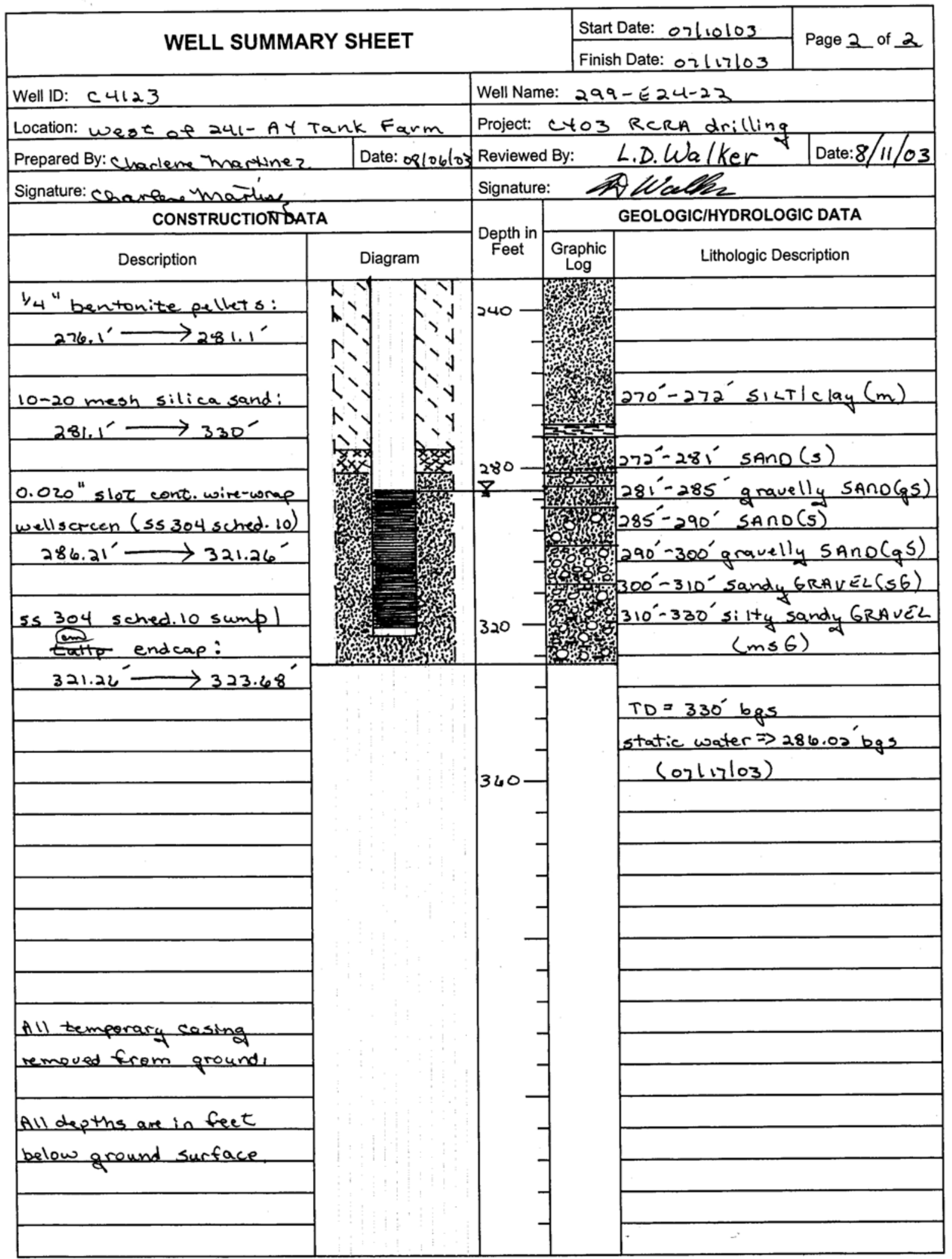




\section{WELL CONSTRUCTION SUMMARY REPORT}

Page $\perp$ of 1

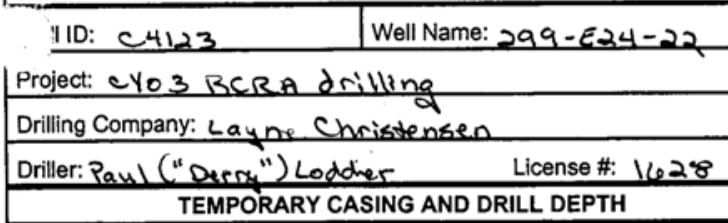




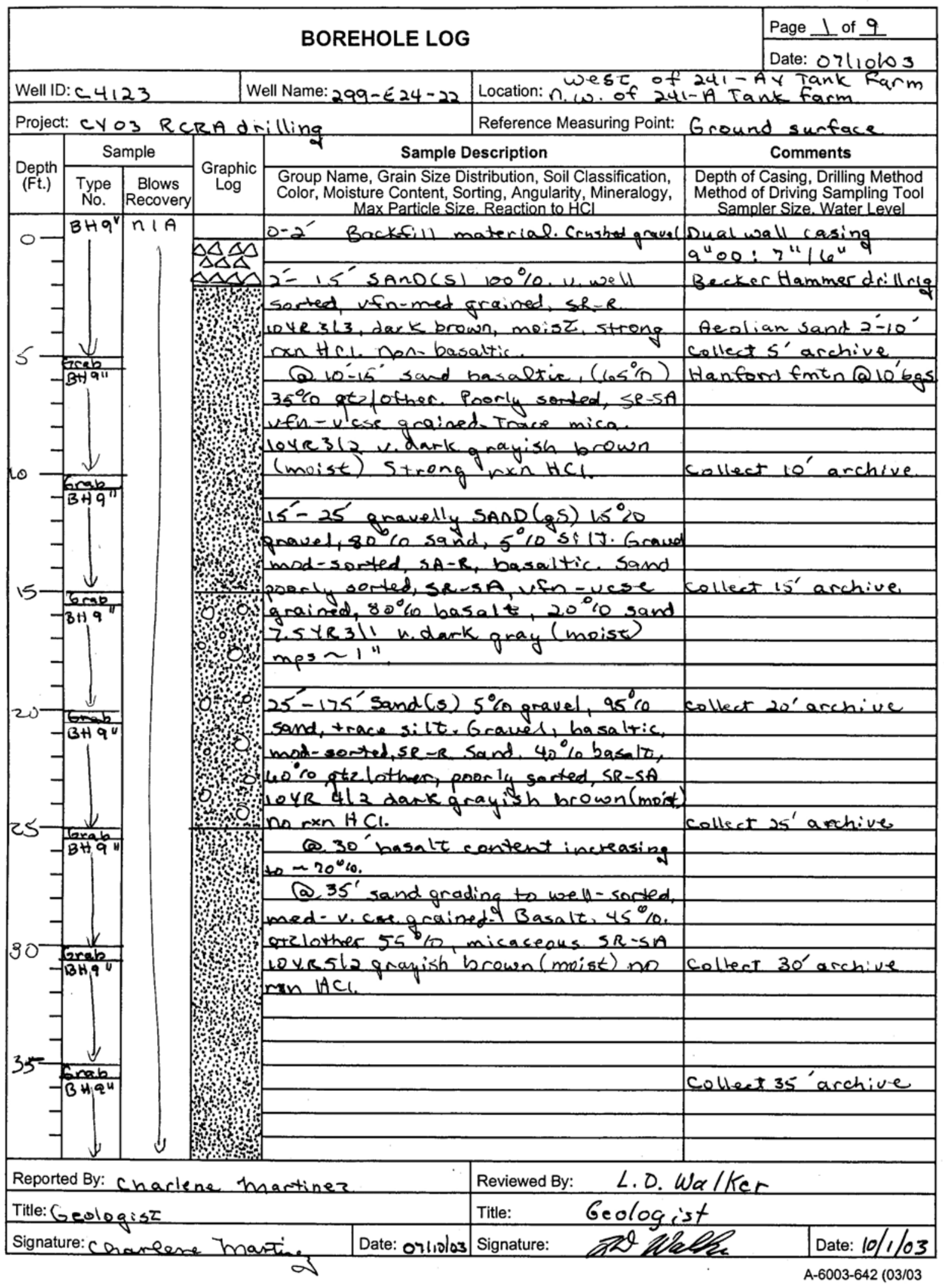




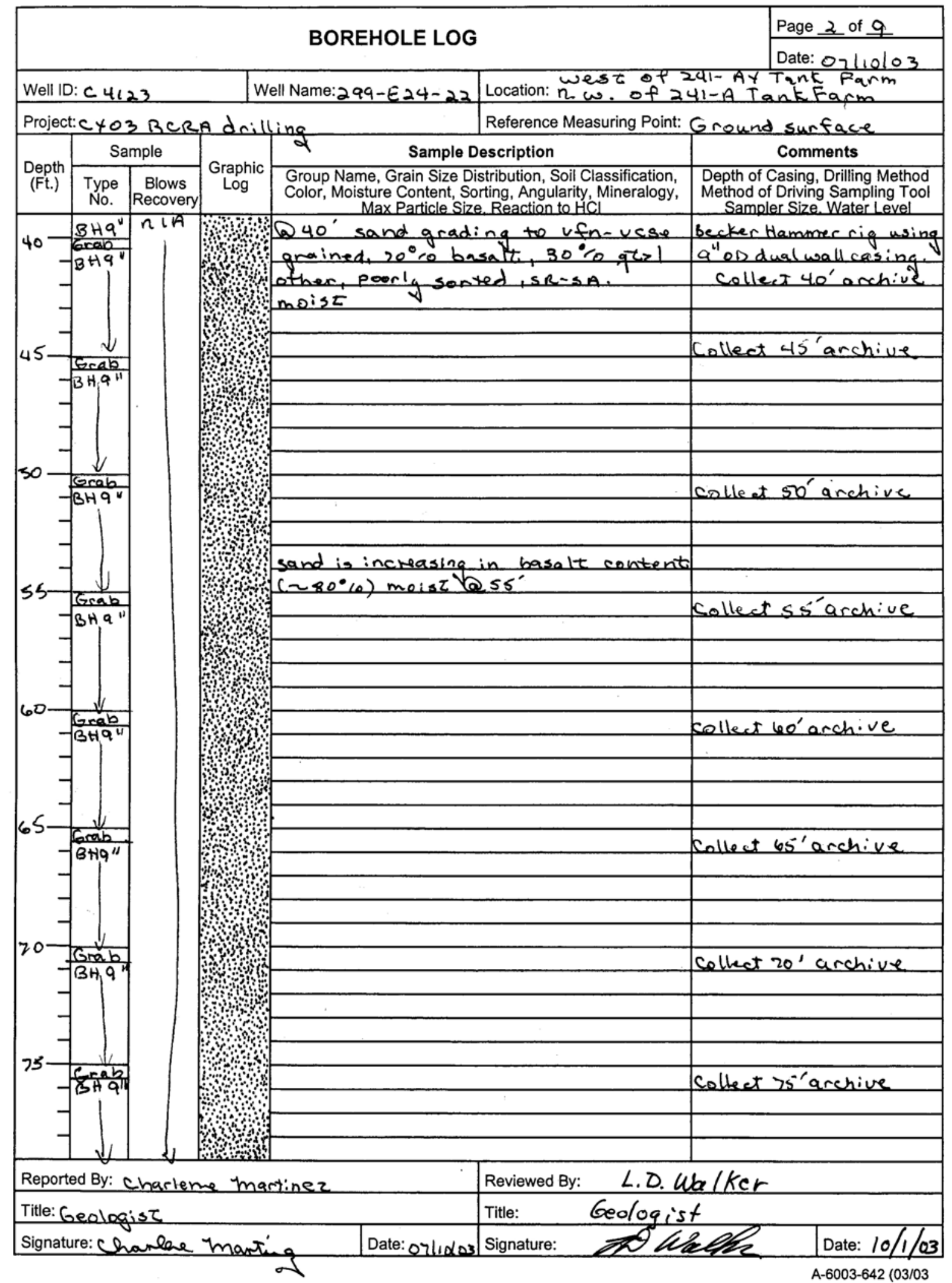




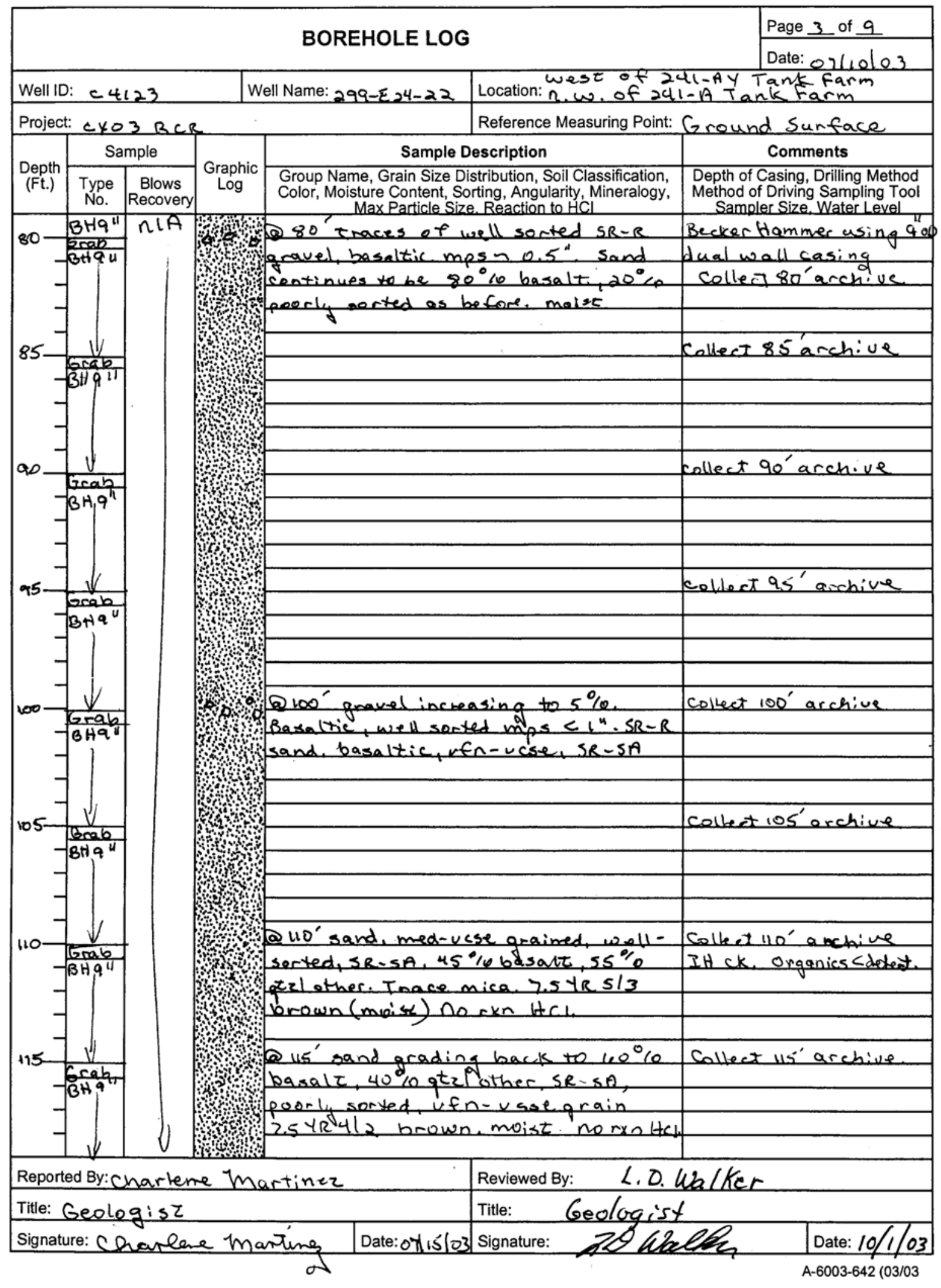




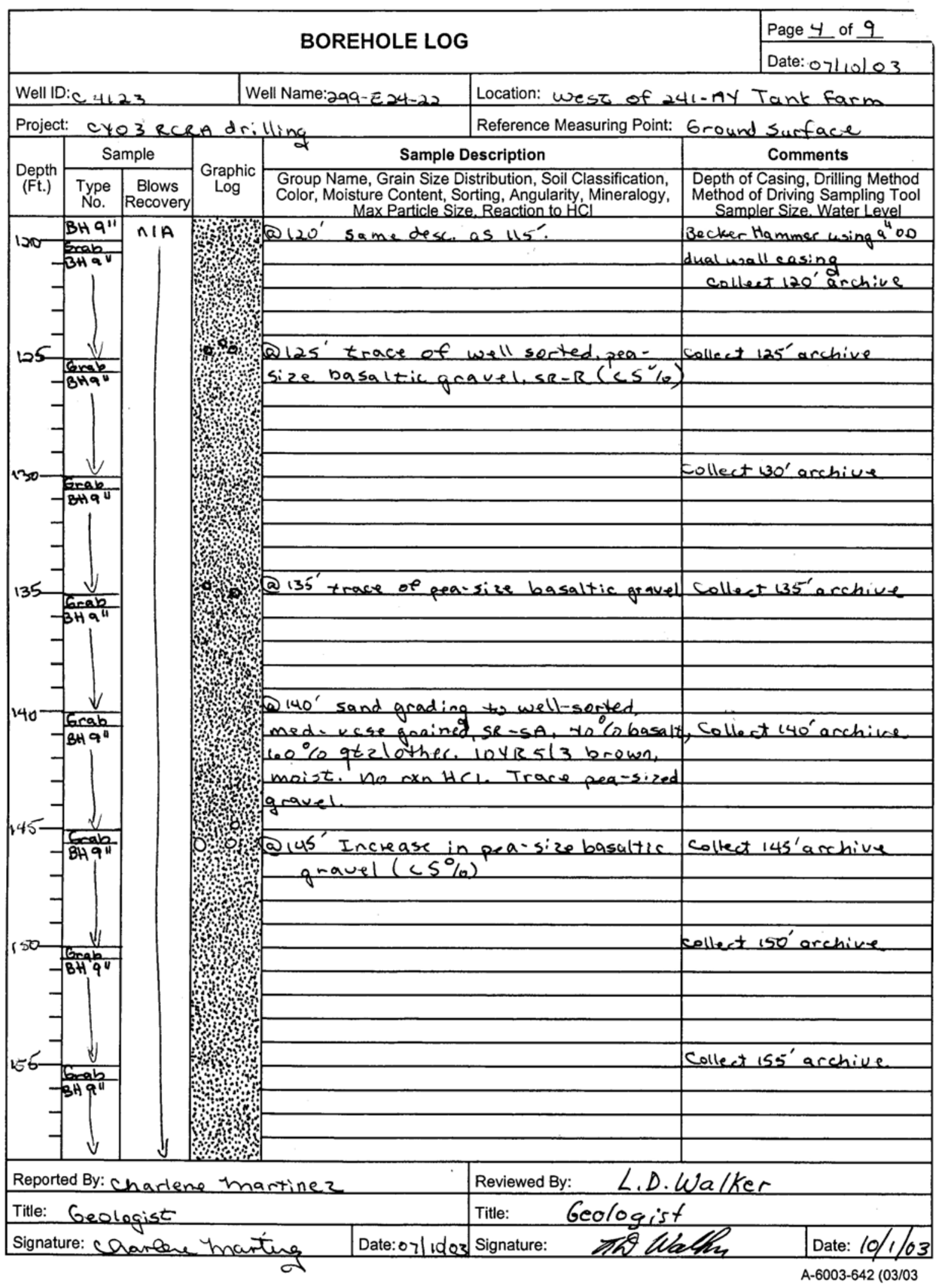




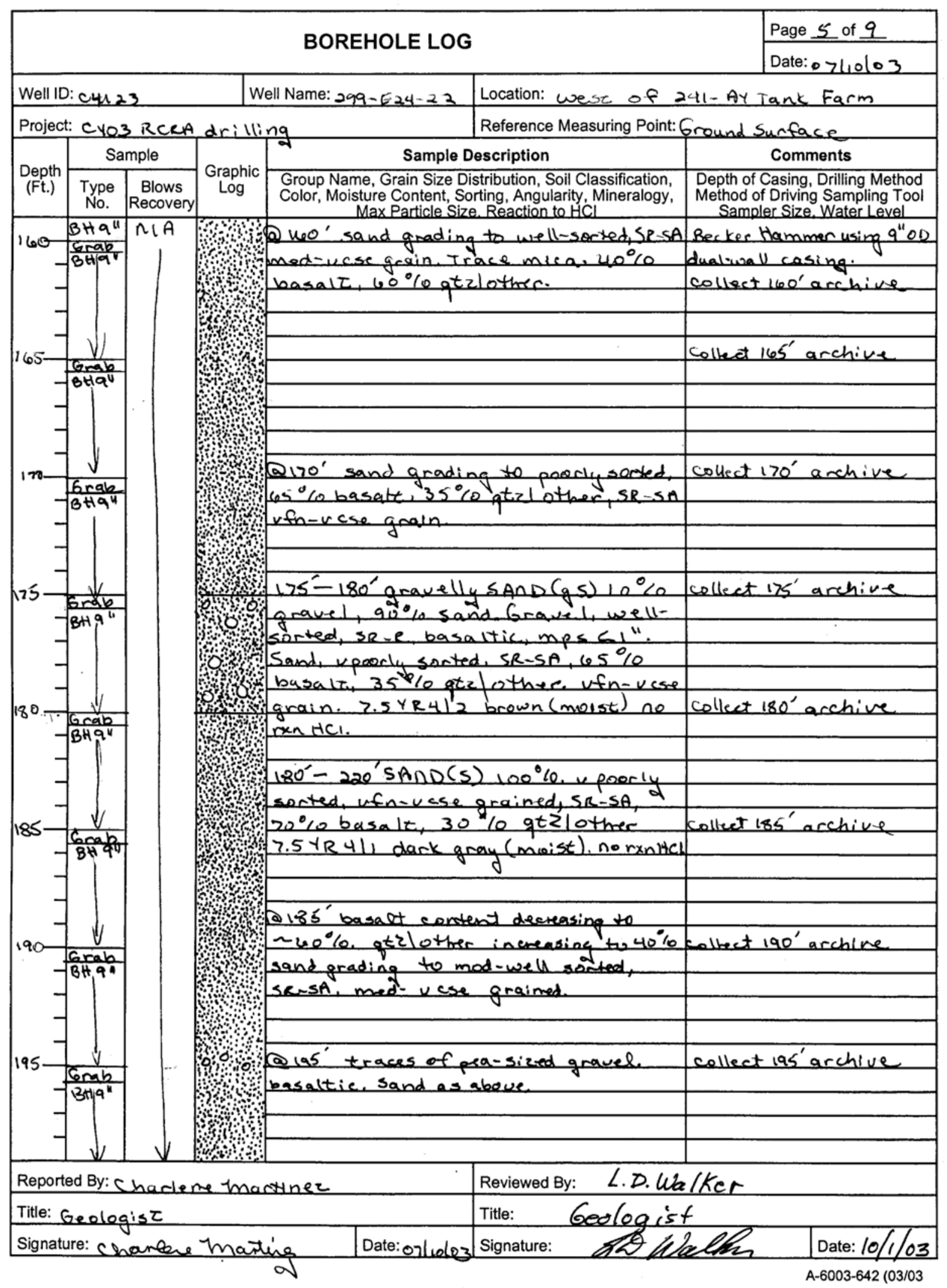




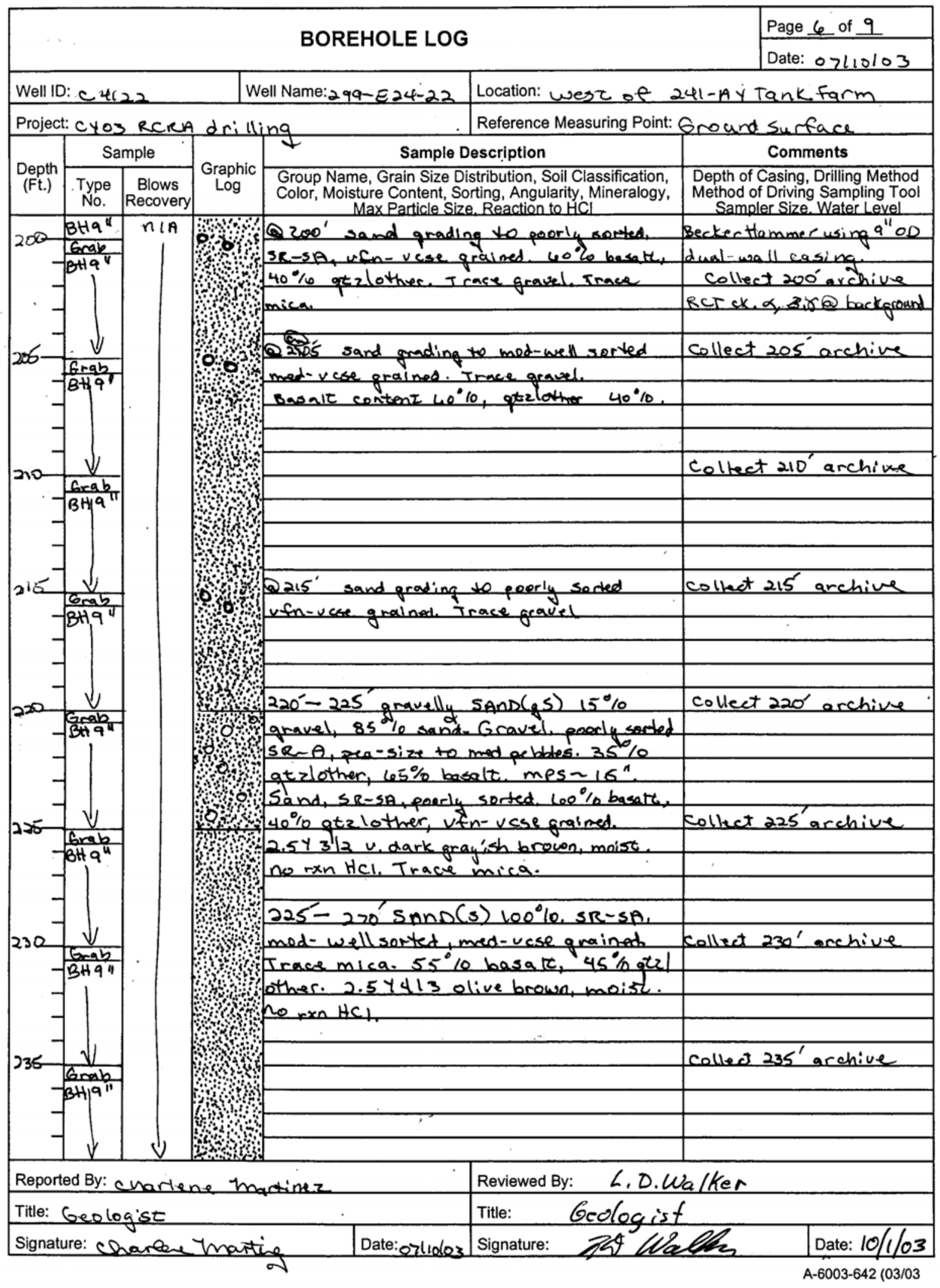




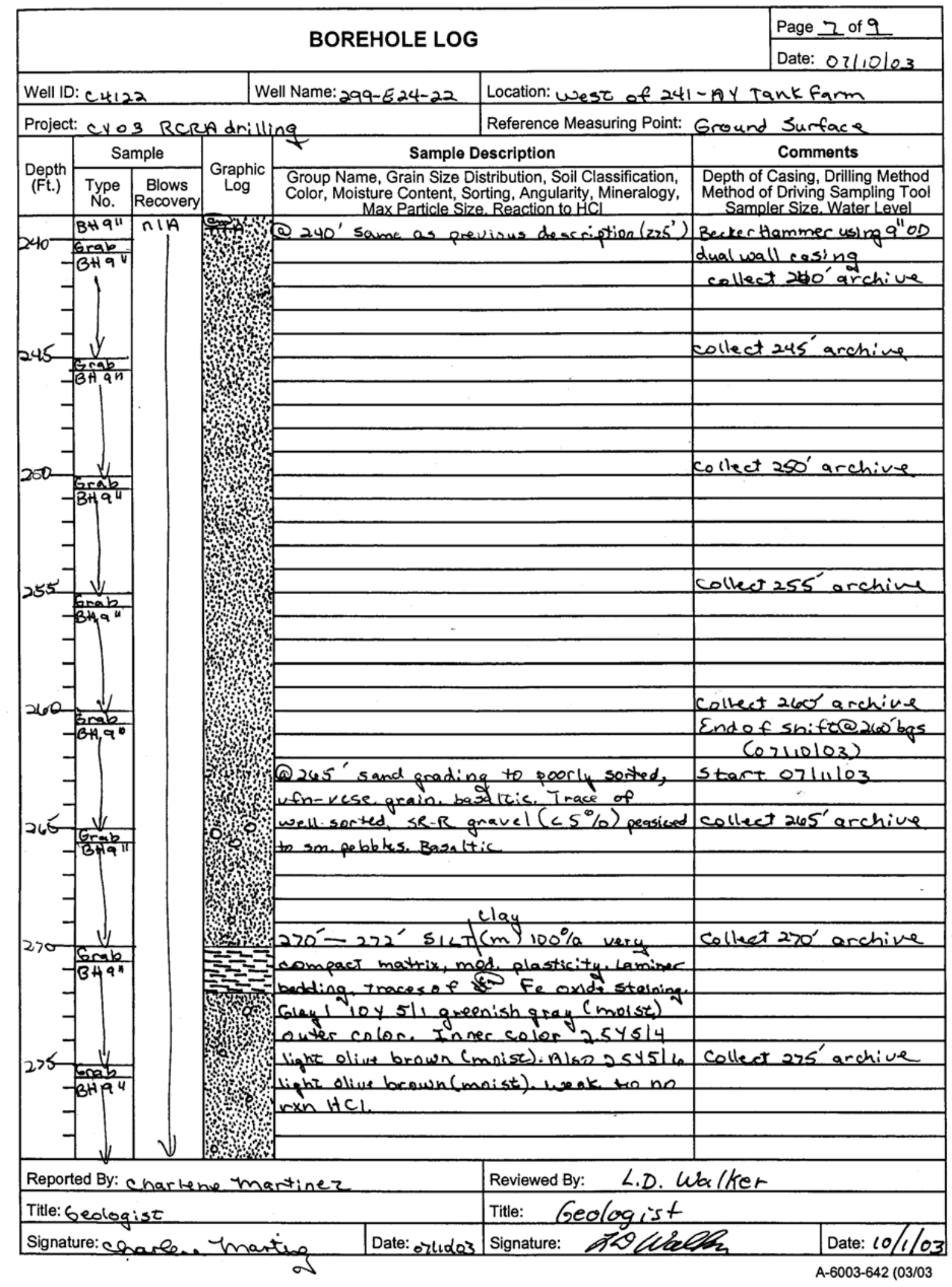




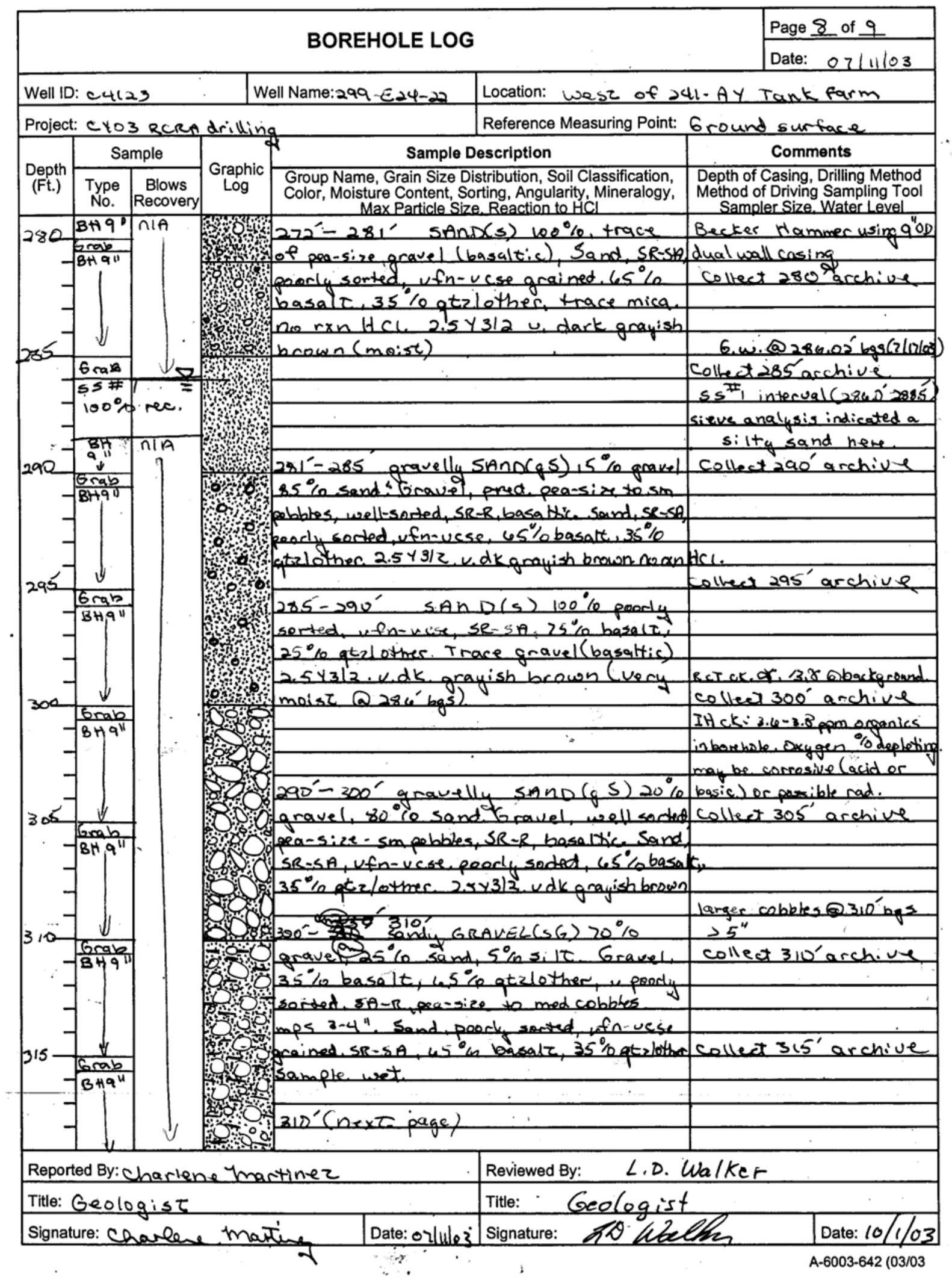




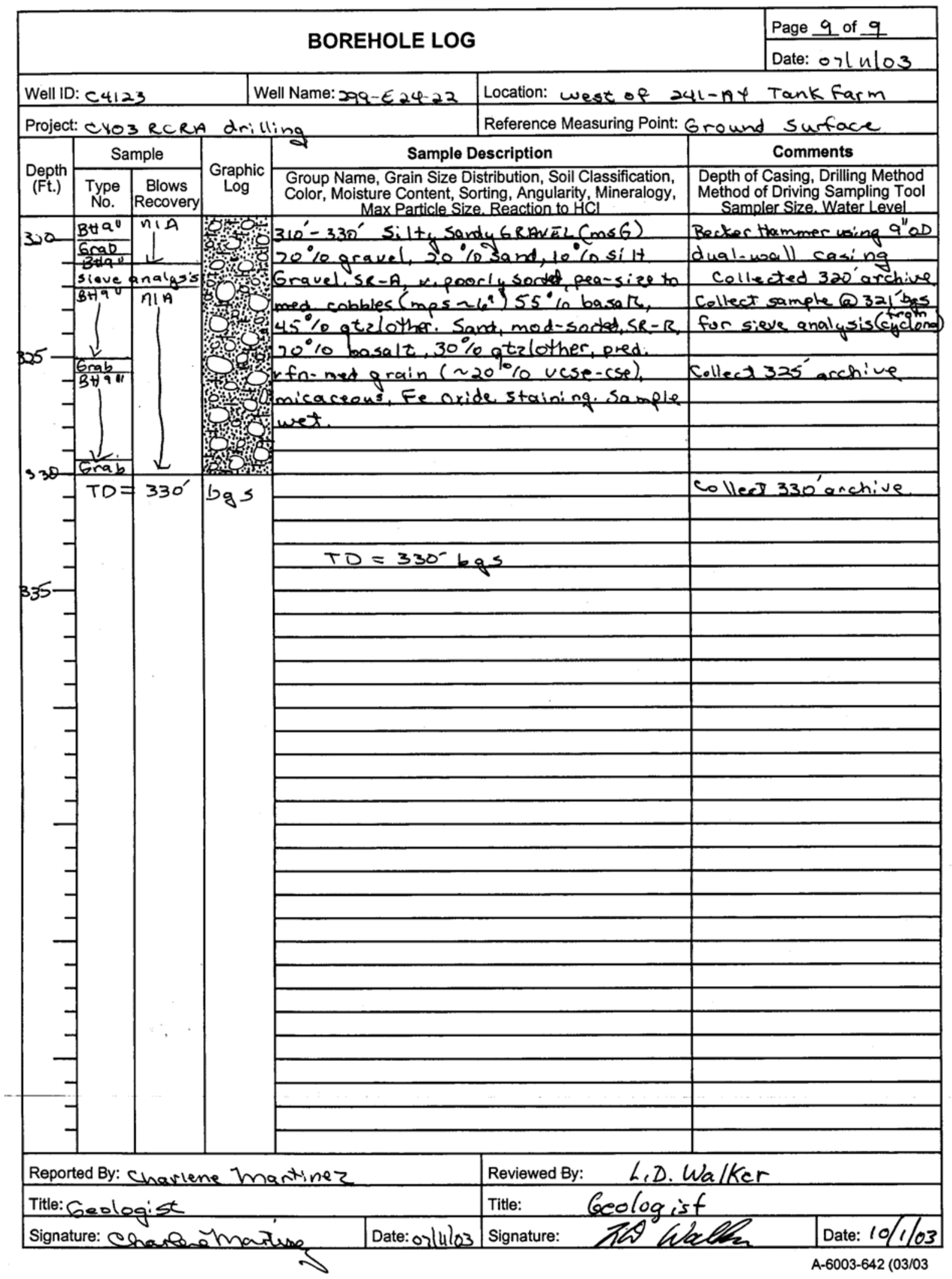




\section{WELL DEVELOPMENT AND TESTING DATA}

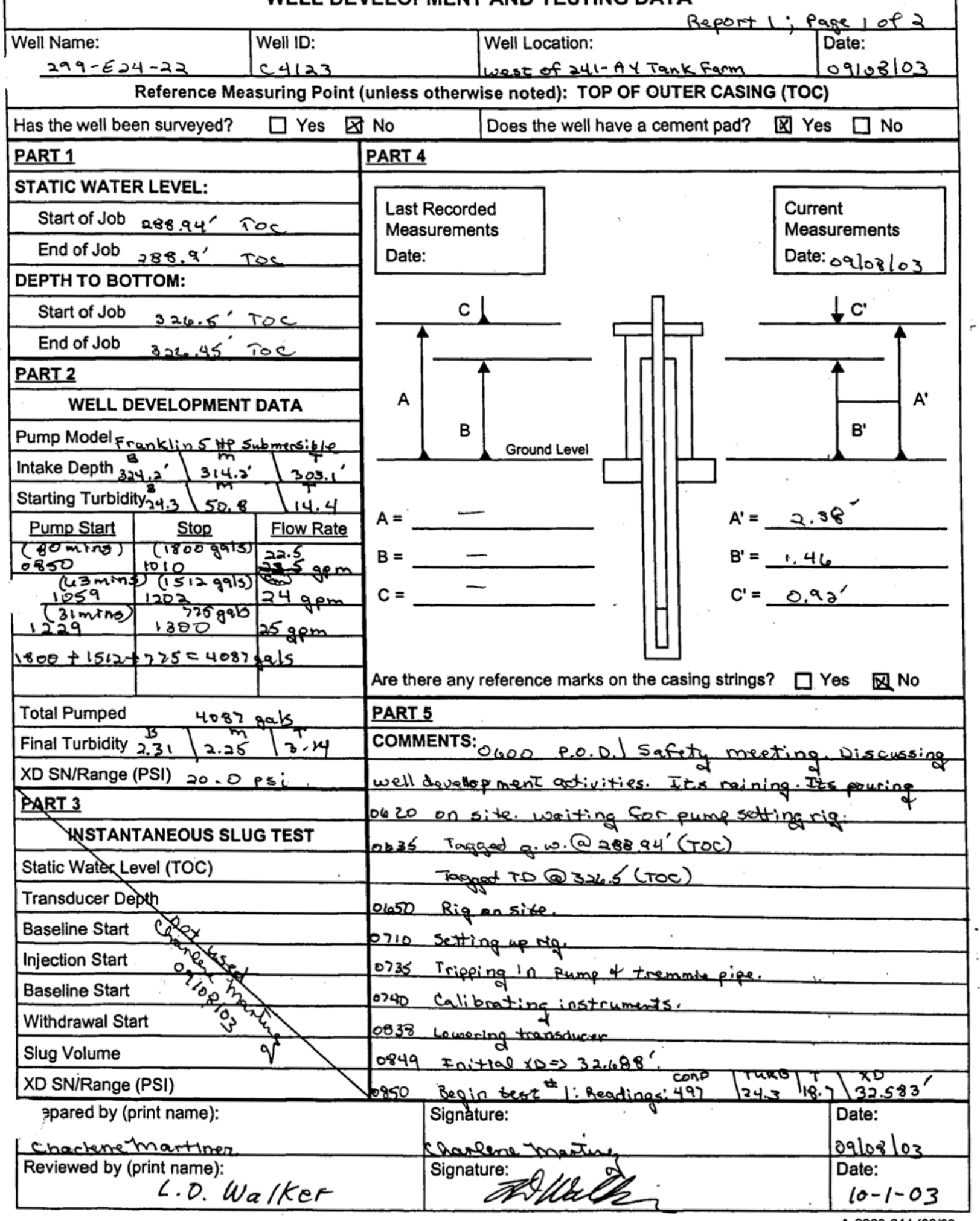




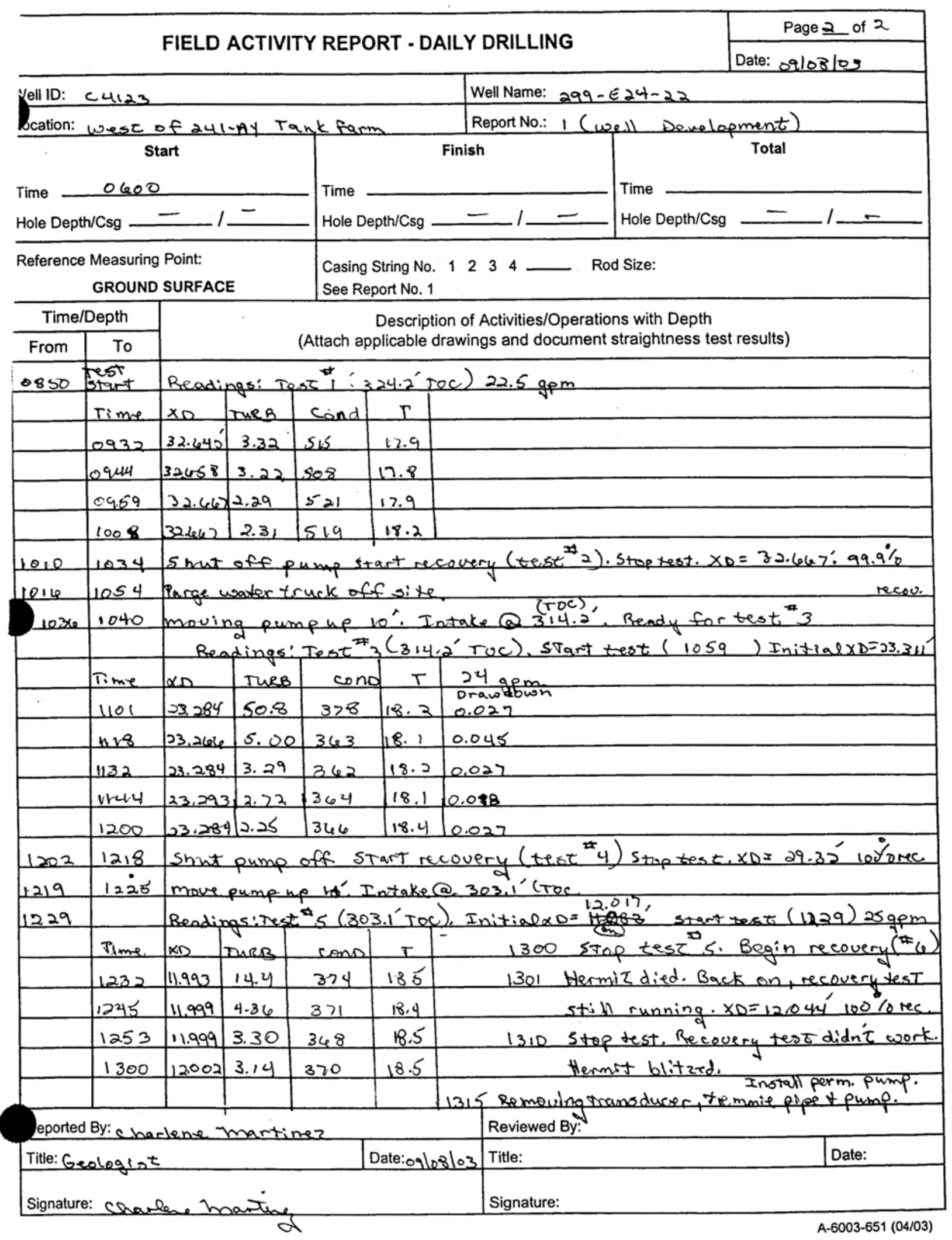




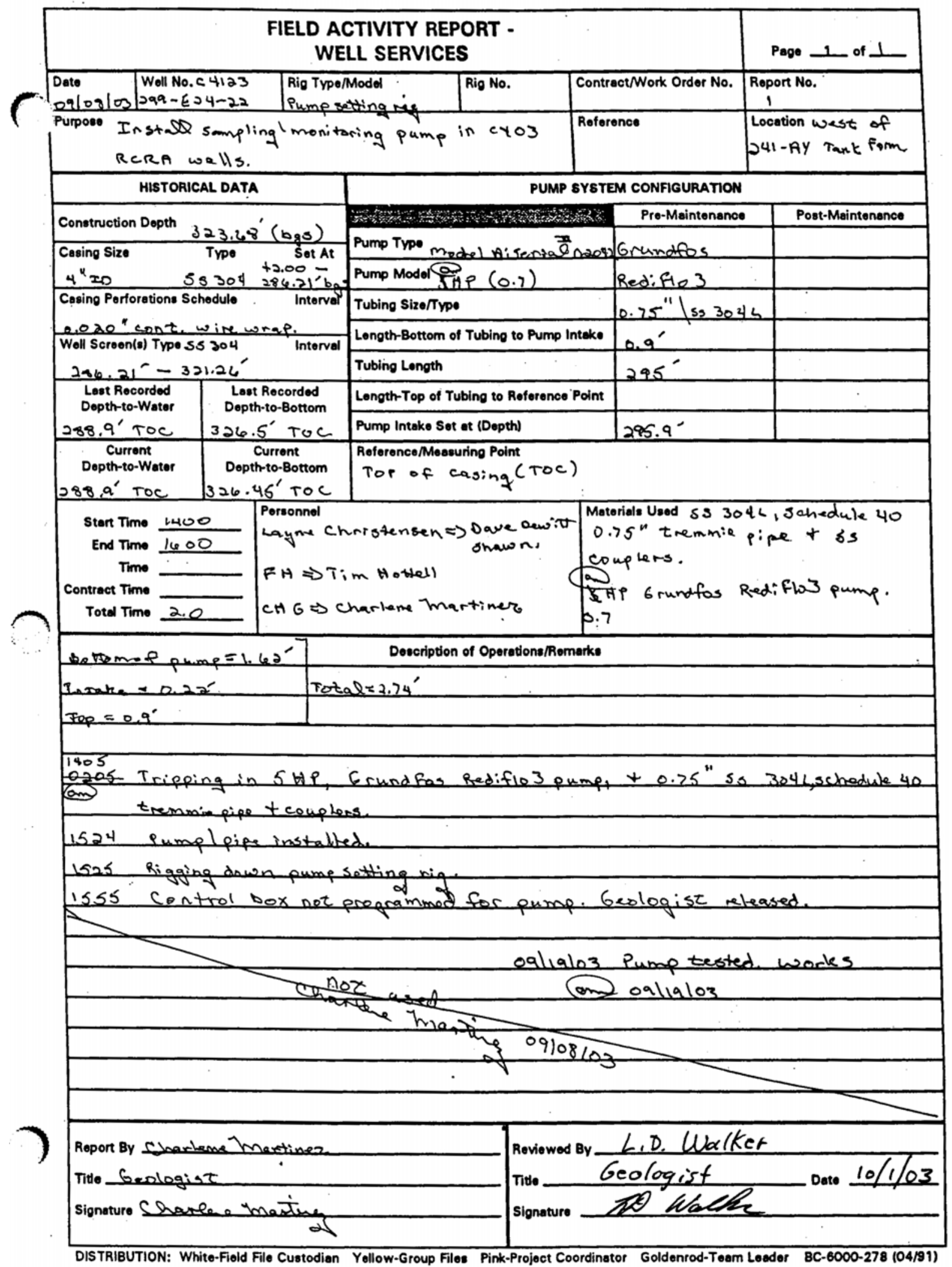




\begin{tabular}{|c|c|c|c|c|c|c|}
\hline \multicolumn{7}{|c|}{ WELL SURVEY DATA REPORT } \\
\hline \multicolumn{3}{|l|}{ Project: } & \multicolumn{4}{|c|}{$\begin{array}{ll}\text { Prepared By: } & \text { Neil P. Fastabend } \\
\text { Company: } & \text { Fluor Federal Services }\end{array}$} \\
\hline \multicolumn{3}{|c|}{ Date Requested: $9 / 29 / 03$} & \multicolumn{4}{|c|}{ Requestor: Chris S. Wright (FH) } \\
\hline \multicolumn{3}{|c|}{ Date of Survey: $10 / 31 / 03$} & \multicolumn{4}{|c|}{$\begin{aligned} \text { Surveyor: } & \text { Fluor Federal Services } \\
& \text { Survey Dept. }\end{aligned}$} \\
\hline \multicolumn{3}{|c|}{ ERC Point of Contact: } & \multicolumn{4}{|c|}{$\begin{array}{l}\text { Survey Co. Point of Contact: } \\
\text { Grant F. Brazil, P.L.S. }\end{array}$} \\
\hline \multirow{4}{*}{\multicolumn{3}{|c|}{$\begin{array}{l}\text { Description of Work: } \\
\text { Civil Survey of Groundwater Monitoring } \\
\text { Well C4123 (299-E24-22). }\end{array}$}} & \multicolumn{4}{|c|}{ Horizontal Datum: NAD83(91) } \\
\hline & & & \multicolumn{4}{|c|}{ Vertical Datum: NAVD88 } \\
\hline & & & \multicolumn{4}{|c|}{ Units: $\quad$ Meters } \\
\hline & & & \multicolumn{4}{|c|}{ Hanford Area Designation: $200 E$} \\
\hline \multicolumn{7}{|c|}{ Coordinate System: Washington State Plane Coordinates (South Zone) } \\
\hline \multicolumn{7}{|c|}{$\begin{array}{l}\text { Horizontal Control Monuments: } \\
\qquad 2 \mathrm{E}-127(\mathrm{FFS}) \text { and } 2 \mathrm{E}-134 \text { (FFS) }\end{array}$} \\
\hline \multicolumn{7}{|c|}{$\begin{array}{l}\text { Vertical Control Monuments: } \\
\qquad 2 \mathrm{E}-18(\mathrm{FFS}) \text { and } 2 \mathrm{E}-38(\mathrm{FFS})\end{array}$} \\
\hline Well ID & Well Name & Easting & & Northing & Elevation & \\
\hline \multirow[t]{4}{*}{ C4123 } & 299-E24-22 & 575262.6 & & 136142.82 & & Center of Casing \\
\hline & & & & & 210.285 & $\begin{array}{l}\text { Top Casing, } \\
\text { N. Edge }\end{array}$ \\
\hline & & & & & 209.553 & Brass Survey Marker \\
\hline & & & & & 210.291 & $\begin{array}{l}\text { Top Pump Base- } \\
\text { plate, N. Edge }\end{array}$ \\
\hline \multicolumn{7}{|l|}{ Notes: } \\
\hline \multicolumn{7}{|c|}{$\begin{array}{l}\text { Surveyor Statement: } \\
\text { I, Grant F. Brazil, a Professional Land Surveyor registered } \\
\text { in the State of Washington (Registration No. 22326), hereby } \\
\text { certify that this report is based on a field survey performed in } \\
\text { October, } 2003 \text { under my direct supervision, and that the data } \\
\text { contained here is true and correct. }\end{array}$} \\
\hline
\end{tabular}

Original to:

Distribution by DIS: 


\section{Appendix B}

Sediment Samples Physical Properties Data 


\begin{tabular}{|c|c|c|c|c|c|c|}
\hline \multicolumn{7}{|c|}{ CH2M Hill Hanford, Inc. } \\
\hline WELL NAME & 299-E25-93 & DEPTH & $280.0-282.5$ & SAMPLE\# & E25-93-280.0 & WELL ID\# \\
\hline TESTED BY & CRM & CONTACT & Dave Weekes & PHONE & $372-9350$ & $07 / 107 / 2003$ \\
\hline $\begin{array}{l}\text { SAMPLE } \\
\text { WT }(\mathrm{g}) \\
\end{array}$ & $\begin{array}{c}\text { SIEVE } \\
\text { SIZE IN. }\end{array}$ & $\begin{array}{c}\text { CUMULATIVE } \\
\text { WEIGHT(g) }\end{array}$ & $\begin{array}{l}\% \text { WEIGHT } \\
\text { RETAINED } \\
\end{array}$ & $\begin{array}{c}\% \\
\text { PASSING } \\
\end{array}$ & $\begin{array}{c}\begin{array}{c}\text { Grain Size } \\
(\mathrm{mm})\end{array} \\
\end{array}$ & COMMENTS \\
\hline 1307.00 & $2^{n}$ & 0.0 & 0.0 & 100.0 & 50.80 & \\
\hline & $1.5^{n}$ & 0.0 & 0.0 & 100.0 & 38.10 & \\
\hline & $3 / 4^{n}$ & 0.0 & 0.0 & 100.0 & 19.05 & \\
\hline & $3 / 8^{n}$ & 296.0 & 22.6 & 77.4 & 9.42 & \\
\hline & $\# 4$ & 653.8 & 50.0 & 50.0 & 4.70 & \\
\hline & $\# 10$ & 965.0 & 73.8 & 26.2 & 1.98 & \\
\hline & $\# 20$ & 1147.7 & 87.8 & 12.2 & 0.83 & \\
\hline & $\# 40$ & 1220.6 & 93.4 & 6.6 & 0.42 & \\
\hline & $\# 60$ & 1256.5 & 96.1 & 3.9 & 0.25 & \\
\hline & $\# 100$ & 1275.9 & 97.6 & 2.4 & 0.150 & \\
\hline & $\# 200$ & 1288.4 & 98.6 & 1.4 & 0.074 & \\
\hline
\end{tabular}

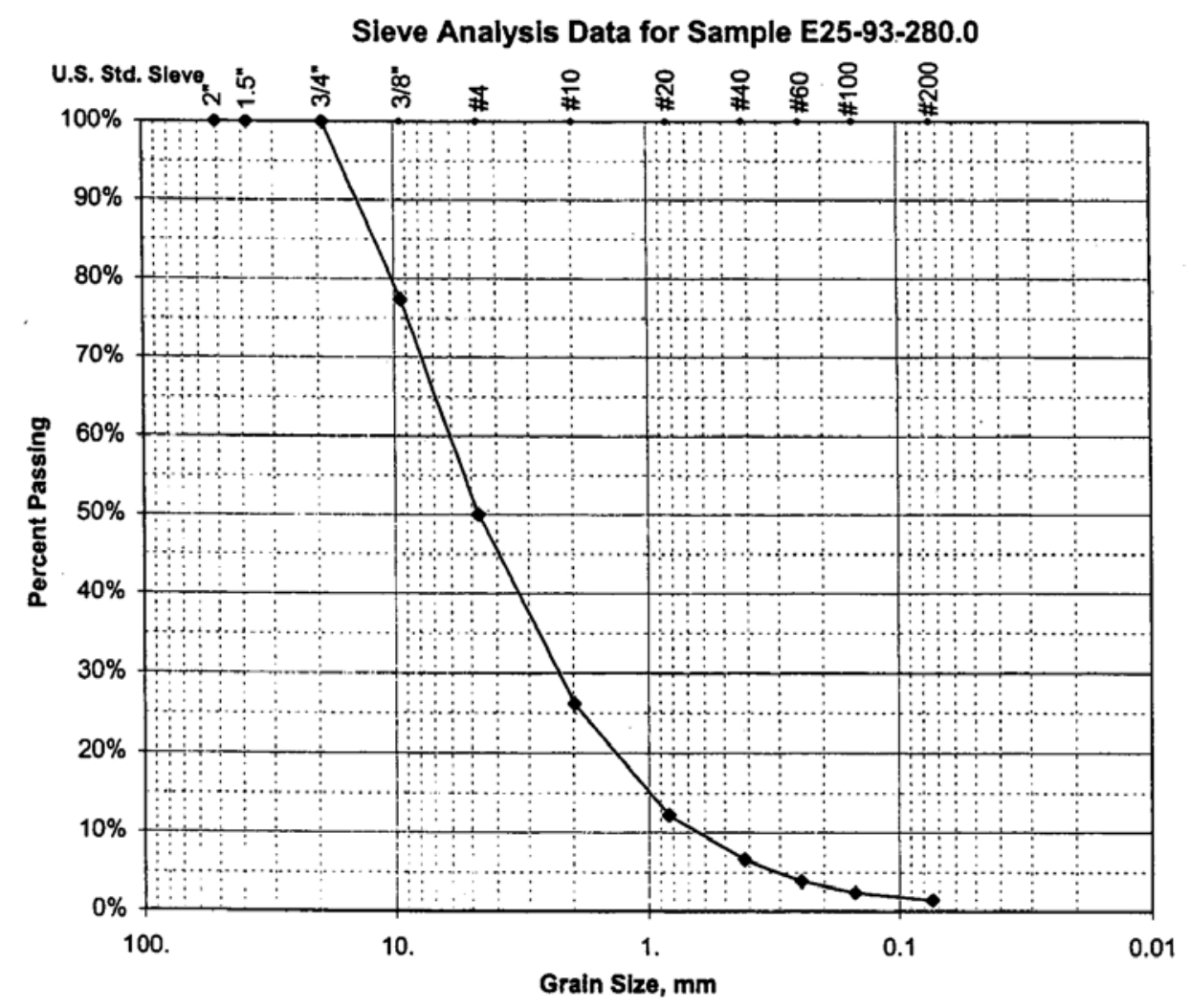

Comments: Gravel - Field geologist collected sample from cyclone. Split spoon had $0 \%$ recovery. Sieve analysis may not be representative of formation due to collection method. All data are accurately and completely recorded.

Checked By: L.D. Wbalker

B.1 
CH2M Hill Hanford, Inc.

SIEVE ANALYSIS

\begin{tabular}{|c|c|c|c|c|c|c|}
\hline WELL NAME & 299-E25-93 & DEPTH & $315.0-317.5$ & SAMPLE\# & E25-93-315.0 & WELL ID\# \\
\hline TESTED BY & CRM & CONTACT & Dave Weekes & PHONE & $372-9350$ & $07 / 07 / 2003$ \\
\hline SAMPLE & SIEVE & CUMULATIVE & $\%$ WEIGHT & $\%$ & Grain Size & COMMENTS \\
\hline WT (g) & SIZE IN. & WEIGHT(g) & RETAINED & PASSING & $(\mathrm{mm})$ & \\
\hline 1067.40 & $2^{n}$ & 0.0 & 0.0 & 100.0 & 50.80 & \\
\hline & $1.5^{n}$ & 0.0 & 0.0 & 100.0 & 38.10 & \\
\hline & $3 / 4^{\prime \prime}$ & 0.0 & 11.9 & 88.1 & 19.05 & \\
\hline & $3 / 8^{n}$ & 127.5 & 34.1 & 65.9 & 9.42 & \\
\hline & $\# 4$ & 363.9 & 44.1 & 55.9 & 4.70 & \\
\hline & $\# 10$ & 471.1 & 47.8 & 52.2 & 1.98 & \\
\hline & $\# 20$ & 510.2 & 49.1 & 50.9 & 0.83 & \\
\hline & $\# 40$ & 523.9 & 58.4 & 41.6 & 0.42 & \\
\hline & $\# 60$ & 623.1 & 69.5 & 30.5 & 0.25 & \\
\hline & $\# 100$ & 741.9 & 77.4 & 22.6 & 0.150 & \\
\hline & $\# 200$ & 1288.4 & 91.1 & 8.9 & 0.074 & \\
\hline
\end{tabular}

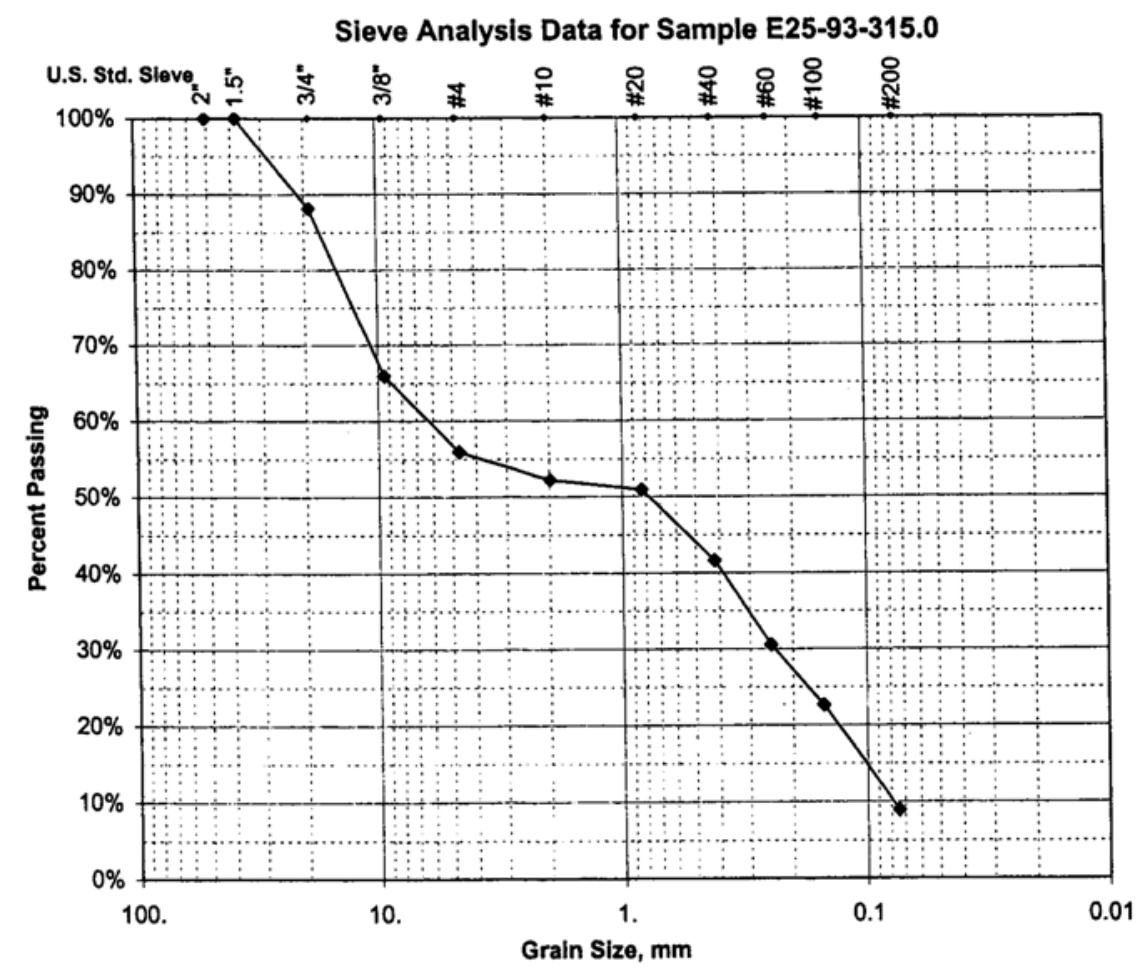

Comments: Gravel - Field geologist collected sample from cyclone. Split spoon had $0 \%$ recovery. Sieve analysis may not be representative of formation due to collection method.

All data are accurately and completely recorded.

Checked By: L.D. Walker Date: $10-1-03$ 
CH2M Hill Hanford, Inc.

SIEVE ANALYSIS

\begin{tabular}{|c|c|c|c|c|c|c|}
\hline WELL NAME & 299-E24-22 & DEPTH & $286.0-288.5$ & SAMPLE\# & E24-22-286.0 & WELL ID\# \\
\hline TESTED BY & CRM & CONTACT & Dave Weekes & PHONE & $372-9350$ & $07 / 14 / 2003$ \\
\hline $\begin{array}{l}\text { SAMPLE } \\
\text { WT }(g)\end{array}$ & $\begin{array}{l}\text { SIEVE } \\
\text { SIZE IN. }\end{array}$ & $\begin{array}{c}\text { CUMULATIVE } \\
\text { WEIGHT(g) }\end{array}$ & $\begin{array}{l}\text { \% WEIGHT } \\
\text { RETAINED }\end{array}$ & $\begin{array}{c}\% \\
\text { PASSING }\end{array}$ & $\begin{array}{c}\text { Grain Size } \\
(\mathrm{mm})\end{array}$ & COMMENTS \\
\hline \multirow[t]{11}{*}{1262.60} & $2^{\prime \prime}$ & 0.0 & 0.0 & 100.0 & 50.80 & \\
\hline & $1.5^{\prime \prime}$ & 0.0 & 0.0 & 100.0 & 38.10 & \\
\hline & $3 / 4^{\prime \prime}$ & 0.0 & 0.0 & 100.0 & 19.05 & \\
\hline & $3 / 8^{\prime \prime}$ & 30.9 & 2.4 & 97.6 & 9.42 & \\
\hline & $\# 4$ & 47.2 & 3.7 & 96.3 & 4.70 & \\
\hline & $\# 10$ & 74.6 & 5.9 & 94.1 & 1.98 & \\
\hline & $\# 20$ & 409.0 & 32.4 & 67.6 & 0.83 & \\
\hline & $\# 40$ & 856.6 & 67.8 & 32.2 & 0.42 & \\
\hline & $\# 60$ & 990.9 & 78.5 & 21.5 & 0.25 & \\
\hline & $\# 100$ & 1060.3 & 84.0 & 16.0 & 0.150 & \\
\hline & $\# 200$ & 1124.1 & 89.0 & 11.0 & 0.074 & \\
\hline
\end{tabular}

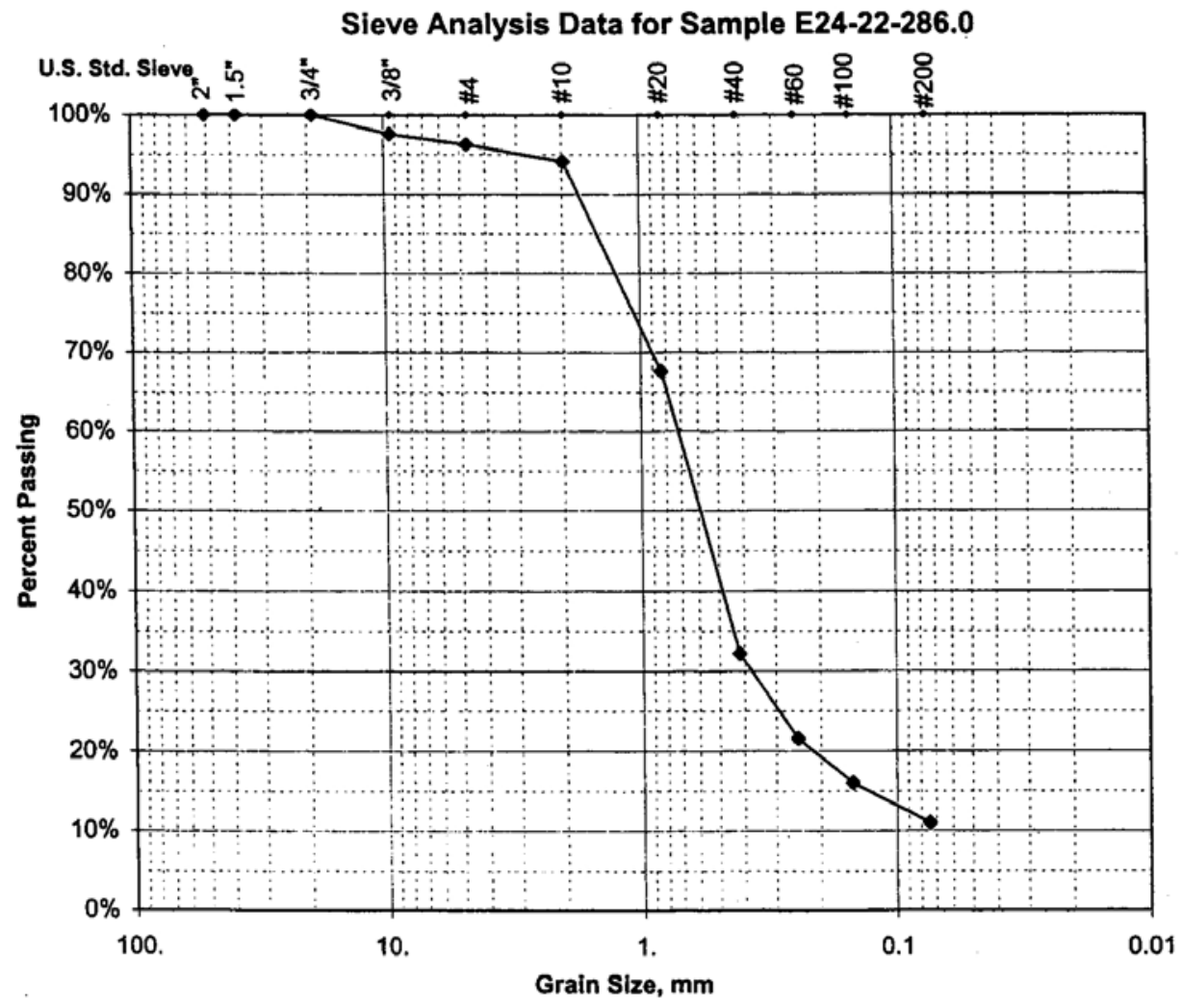

Comments: Silty Sand.

All data are accurately and completely recorded.

Checked By: 2.0. WhelKCE

Date: $10-1-03$

B.3 


\begin{tabular}{|c|}
\hline CH2M Hill Hanford, Inc. \\
SIEVE ANALYSIS \\
\hline
\end{tabular}

\begin{tabular}{|c|c|c|c|c|c|c|}
\hline WELL NAME & 299-E24-22 & DEPTH & 321 & SAMPLE\# & E24-22-321.0 & $\overline{\text { WELL ID\# }}$ \\
\hline TESTED BY & CRM & CONTACT & Dave Weekes & PHONE & $372-9350$ & $07 / 14 / 2003$ \\
\hline SAMPLE & SIEVE & CUMULATIVE & $\%$ WEIGHT & $\%$ & Grain Size & COMMENTS \\
\hline WT (g) & SIZE IN. & WEIGHT(g) & RETAINED & PASSING & $(\mathrm{mm})$ & \\
\hline 1047.70 & $2^{n}$ & 0.0 & 0.0 & 100.0 & 50.80 & \\
\hline & $1.5^{n}$ & 0.0 & 0.0 & 100.0 & 38.10 & \\
\hline & $3 / 4^{n}$ & 0.0 & 0.0 & 100.0 & 19.05 & \\
\hline & $3 / 8^{n}$ & 109.2 & 10.4 & 89.6 & 9.42 & \\
\hline & $\# 4$ & 353.6 & 33.8 & 66.2 & 4.70 & \\
\hline & $\# 10$ & 718.0 & 68.5 & 31.5 & 1.98 & \\
\hline & \#20 & 931.3 & 88.9 & 11.1 & 0.83 & \\
\hline & $\# 40$ & 989.1 & 94.4 & 5.6 & 0.42 & \\
\hline & $\# 60$ & 1005.4 & 96.0 & 4.0 & 0.25 & \\
\hline . & $\# 100$ & 1015.1 & 96.9 & 3.1 & 0.150 & \\
\hline & $\# 200$ & 1024.6 & 97.8 & 2.2 & 0.074 & \\
\hline
\end{tabular}

Sieve Analysis Data for Sample E24-22-321.0

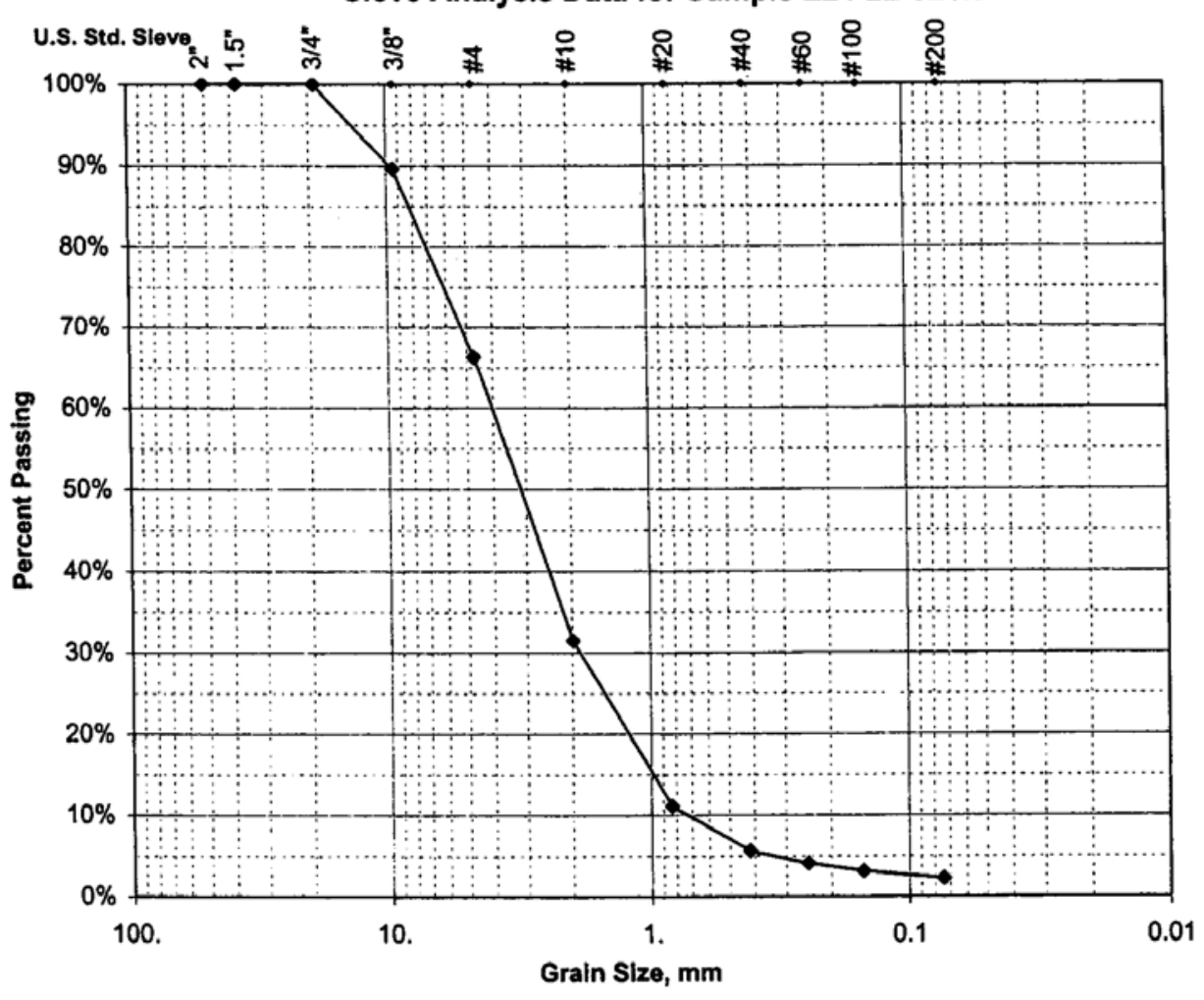

Comments: Gravel. Sample collected from cyclone. Fines washed away.

Sample not representative of formation.

All data are accurately and completely recorded.

Checked By: L.X. Walker Date: $10-1-03$ 


\section{Appendix C}

\section{Borehole Geophysical Logs Gyroscope Surveys}




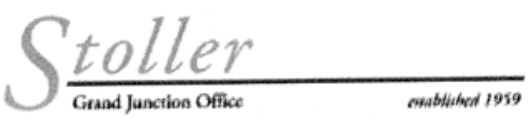

\section{C-4122}

\section{Log Data Report}

\section{Borehole Information:}

\begin{tabular}{|c|c|c|c|c|c|}
\hline \multirow{2}{*}{\multicolumn{2}{|c|}{$\begin{array}{ll}\text { Borehole: } & \text { C-4122 } \\
\text { Coordinates (WA St Plane) }\end{array}$}} & & \multicolumn{3}{|c|}{ Site: East of A Tank Farm } \\
\hline & & GWL' (ft): & 81 & GWL Date: & $07 / 02 / 03$ \\
\hline $\begin{array}{c}\text { North } \\
\text { (estimated) } \\
136020\end{array}$ & $\begin{array}{c}\text { East } \\
\text { (estimated) } \\
575460\end{array}$ & $\begin{array}{c}\text { Drill Date } \\
07 / 03\end{array}$ & $\begin{array}{l}\text { Ground Level } \\
\text { Elevation } \\
\text { Not available }\end{array}$ & $\begin{array}{c}\text { Total Depth (ft) } \\
319.5 \\
\end{array}$ & $\begin{array}{c}\text { Type } \\
\text { Becker }\end{array}$ \\
\hline
\end{tabular}

\section{Casing Information:}

\begin{tabular}{|c|c|c|c|c|c|c|}
\hline Casing Type & Stickup (ft) & $\begin{array}{c}\text { Outer } \\
\text { Diameter } \\
\text { (in.) }\end{array}$ & $\begin{array}{l}\text { Inside } \\
\text { Diameter } \\
\text { (in.) }\end{array}$ & $\begin{array}{l}\text { Thickness } \\
\text { (in.) }\end{array}$ & Top $(f t)$ & Bottom (ft) \\
\hline Threaded Steel & 4.0 & 9.0 & 8.0 & 0.50 & +4.0 & 319.5 \\
\hline Steel Tubing & 4.5 & 6.24 & 6.0 & 0.125 & +4.5 & 319.5 \\
\hline
\end{tabular}

\section{Borehole Notes:}

The casing dimensions are derived from published values for Becker drill casing. Casing thicknesses at the joints are 0.875 -in. and 0.240 -in. for the 8 -in. and 6-in. casings, respectively. The total depth of the borehole was provided by the driller. Total logging depth was $321 \mathrm{ft}, 1.5 \mathrm{ft}$ deeper than reported by the driller. The well site geologist provided the depth to water. Borehole coordinates were provided by Fluor Hanford's person in charge and are estimates. Ground level elevation was not available. Logging data acquisition is referenced to the ground surface.

\section{Logqing Equipment Information:}

\begin{tabular}{|c|c|c|c|}
\hline Logging System: & Gamma 2E & & $\begin{array}{ll}\text { Type: } & \text { SGLS (70\%) SN: } \\
\text { 34TP40587A }\end{array}$ \\
\hline Calibration Date: & $03 / 03$ & Calibration Reference: & GJO-2003-430-TAC \\
\hline & & Logping Procedure: & MAC-HGLP 1.6.5, Rev. 0 \\
\hline
\end{tabular}

\section{Spectral Gamma Logging System (SGLS) Log Run Information:}

\begin{tabular}{|l|c|c|c|c|c|}
\hline Log Run & \multicolumn{1}{l|}{ 2 } & 2 & Repeat & & \\
\hline Date & $07 / 07 / 03$ & $07 / 07 / 03$ & $07 / 07 / 03$ & & \\
\hline Logging Engineer & Spatz & Spatz & Spatz & & \\
\hline Start Depth (ft) & 0.0 & 308.0 & 320.0 & & \\
\hline Finish Depth (ft) & 309.0 & 321.0 & 288.0 & & \\
\hline Count Time (sec) & 100 & 100 & 100 & & \\
\hline Live/Real & $\mathrm{R}$ & $\mathrm{R}$ & $\mathrm{R}$ & & \\
\hline Shield (Y/N) & $\mathrm{N}$ & $\mathrm{N}$ & $\mathrm{N}$ & & \\
\hline MSA Interval (ft) & 1.0 & 1.0 & 1.0 & & \\
\hline ft/min & $\mathrm{N} / \mathrm{A}^{2}$ & $\mathrm{~N} / \mathrm{A}$ & $\mathrm{N} / \mathrm{A}$ & & \\
\hline Pre-Verification & BE055CAB & BE055CAB & BE055CAB & & \\
\hline Start File & BE055000 & BE055310 & BE055324 & & \\
\hline
\end{tabular}

Page 1

C.1 


\begin{tabular}{|l|l|l|l|l|l|}
\hline Log Run & $\mathbf{1}$ & $\mathbf{2}$ & 3 Repeat & & \\
\hline Finish File & BE055309 & BE055323 & BE055356 & & \\
\hline Post-Verification & BE055CAA & BE055CAA & BE055CAA & & \\
\hline $\begin{array}{l}\text { Depth Return Error } \\
\text { (in.) }\end{array}$ & -1.5 & N/A & 0 & & \\
\hline Comments & $\begin{array}{l}\text { Log run } \\
\text { stopped to } \\
\text { refill sonde } \\
\text { with liquid } \\
\text { nitrogen. }\end{array}$ & $\begin{array}{l}\text { Fine-gain } \\
\text { adjustment } \\
\text { made before } \\
\text { resuming } \\
\text { logging. }\end{array}$ & $\begin{array}{l}\text { No fine gain } \\
\text { adjustment. }\end{array}$ & & \\
\hline
\end{tabular}

\section{Logging Operation Notes:}

Spectral gamma logging was performed in this borehole on July 7,2003. Logging was conducted with a centralizer on the sonde, and measurements are referenced to ground surface. A repeat section was collected in this borehole to evaluate system performance.

\section{Analysis Notes:}

\begin{tabular}{|l|l|l|l|l|l|}
\hline Analyst: & Henwood & Date: & $07 / 11 / 03$ & Reference: & GJO-HGLP 1.6.3, Rev. 0 \\
\hline
\end{tabular}

Pre-run and post-run verifications for the logging system were performed before and after data acquisition. The acceptance criteria were met.

A combined casing correction for 0.625 -in.-thick casing was applied throughout the borehole for both casings. The combined thickness at casing joints is 1.115 in. This thickness results in a significant reduction in gamma activity detection as the detector passes by a casing joint. However, it is not practical to correct individual data points for the effect of casing joints. The influence of the thick joints is apparent on the total gamma and ${ }^{40} \mathrm{~K}$ logs where reduced count rates and concentrations are exhibited at approximately $10-\mathrm{ft}$ depth intervals.

SGLS spectra were processed in batch mode using APTEC SUPERVISOR to identify individual energy peaks and determine count rates. Concentrations were calculated with an EXCEL worksheet template identified as G2EMar03.xls using efficiency functions and corrections for casing, water, and dead time as determined from annual calibrations. Dead time corrections are applied where dead times exceed 10.5 percent; no dead times in excess of 10.5 percent were encountered. Correction for water was applied to the data below $281 \mathrm{ft}$.

\section{Log Plot Notes:}

Separate log plots are provided for the man-made radionuclide $\left({ }^{137} \mathrm{Cs}\right)$ detected in the borehole, naturally occurring radionuclides $\left({ }^{40} \mathrm{~K},{ }^{238} \mathrm{U},{ }^{232} \mathrm{Th}[\mathrm{KUT}]\right)$, a combination of man-made, KUT, and dead time, and total gamma plotted with dead time. For each radionuclide, the energy value of the spectral peak used for quantification is indicated. Unless otherwise noted, all radionuclides are plotted in picocuries per gram (pCi/g). The open circles indicate the minimum detectable level (MDL) for each radionuclide. Error bars on each plot represent error associated with counting statistics only and do not include errors associated with the inverse efficiency function, dead time correction, casing corrections, or water corrections. A repeat $\log$ section is also included.

Page 2 


\section{Results and Interpretations:}

${ }^{137} \mathrm{Cs}$ was the only man-made radionuclide detected in this borehole. ${ }^{137} \mathrm{Cs}$ was detected near the ground surface with the maximum concentration of $4.9 \mathrm{pCi} / \mathrm{g}$ detected at 0 - $\mathrm{ft}$ depth. ${ }^{137} \mathrm{Cs}$ was also detected at a few sporadic locations throughout the borehole near its MDL of approximately $0.3 \mathrm{pCi} / \mathrm{g}$.

The repeat sections indicated good agreement of the naturally occurring KUT.

${ }^{\mathrm{I}} \mathrm{GWL}$ - groundwater level

${ }^{2}$ N/A - not applicable

Page 3

C.3 


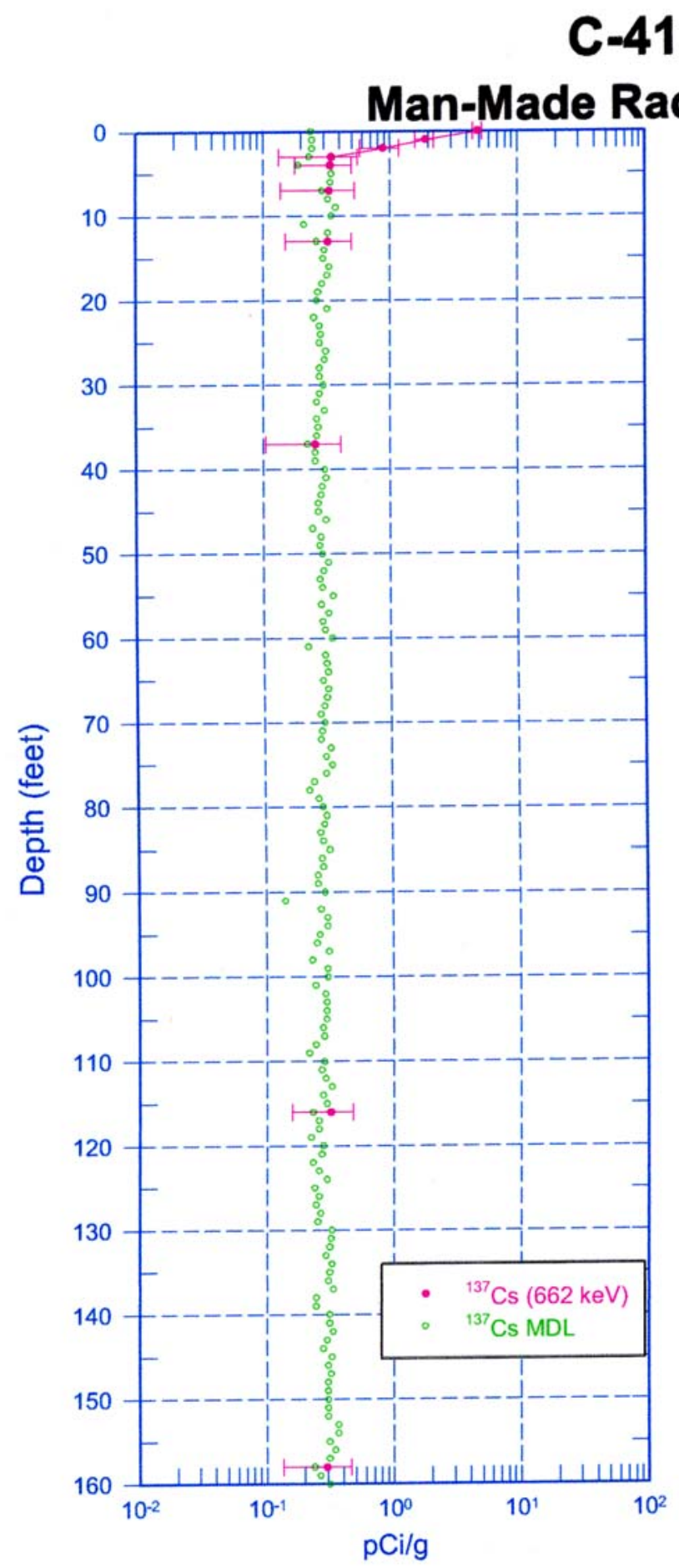

22

dionuclides

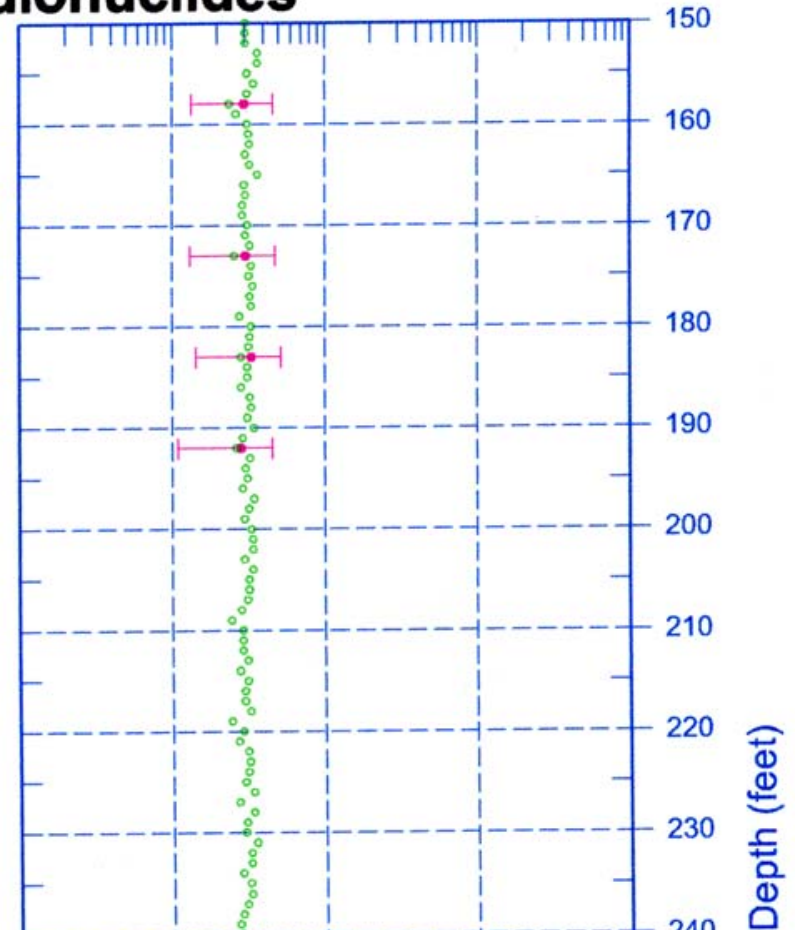

Zero Reference $=$ Ground Surface

Last Log Date - 07/07/03 


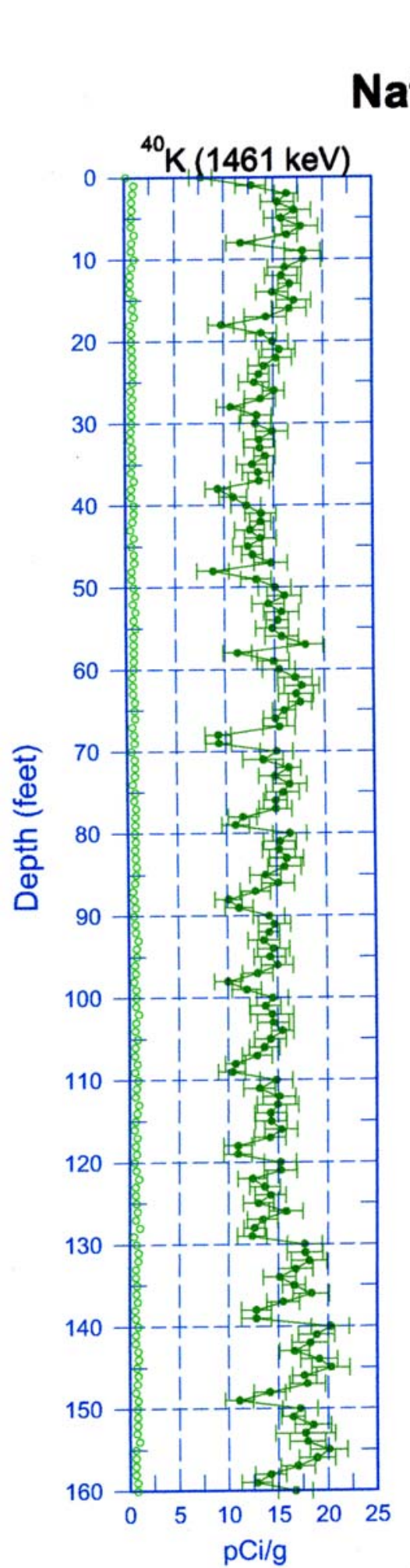

Zero Reference $=$ Ground Surface
C-4122

Natural Gamma Logs
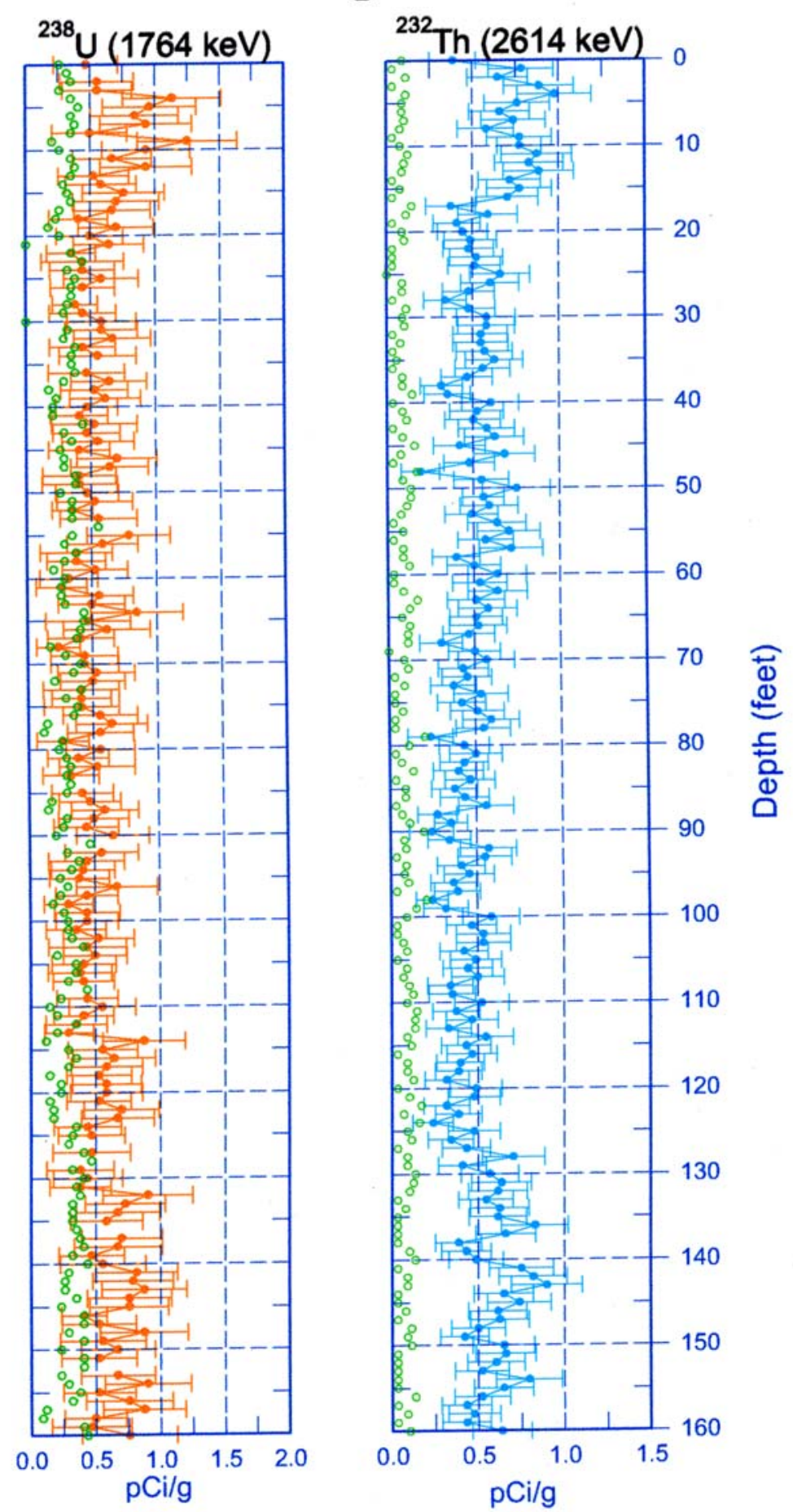

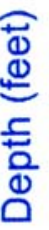

C.5 


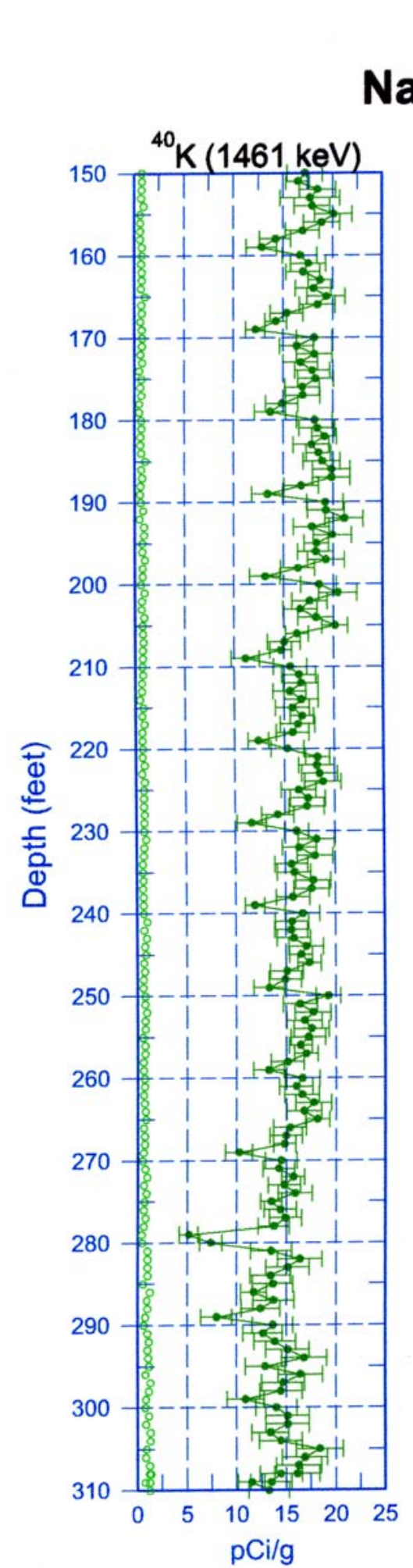

Zero Reference $=$ Ground Surface

C-4122

Natural Gamma Logs

(atural Gamma Logs

${ }^{238} \mathrm{U}(1764 \mathrm{keV})$

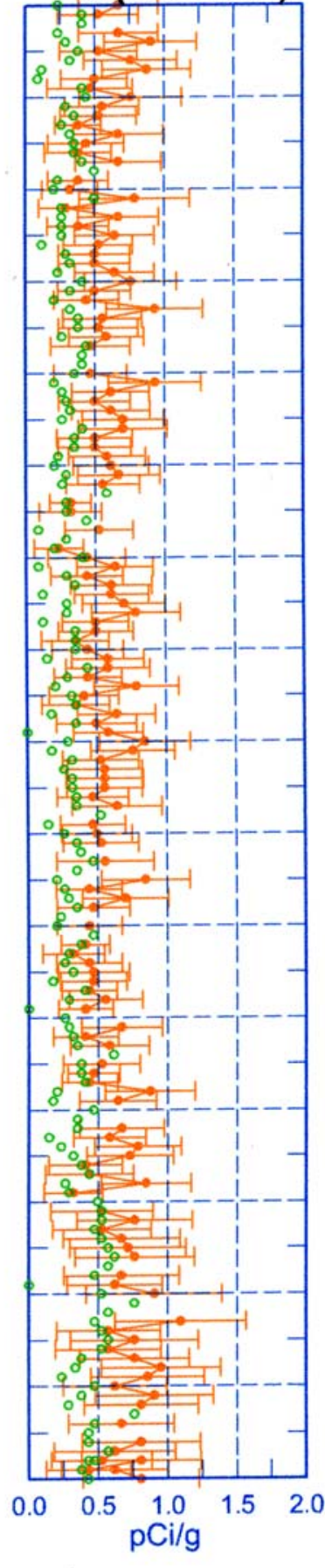

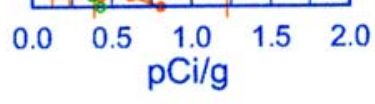

MDL
${ }^{232}$ Th (2614 keV)

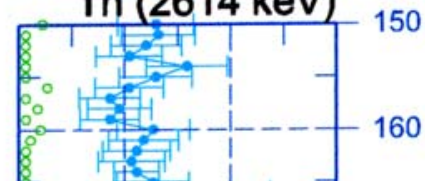

170
0
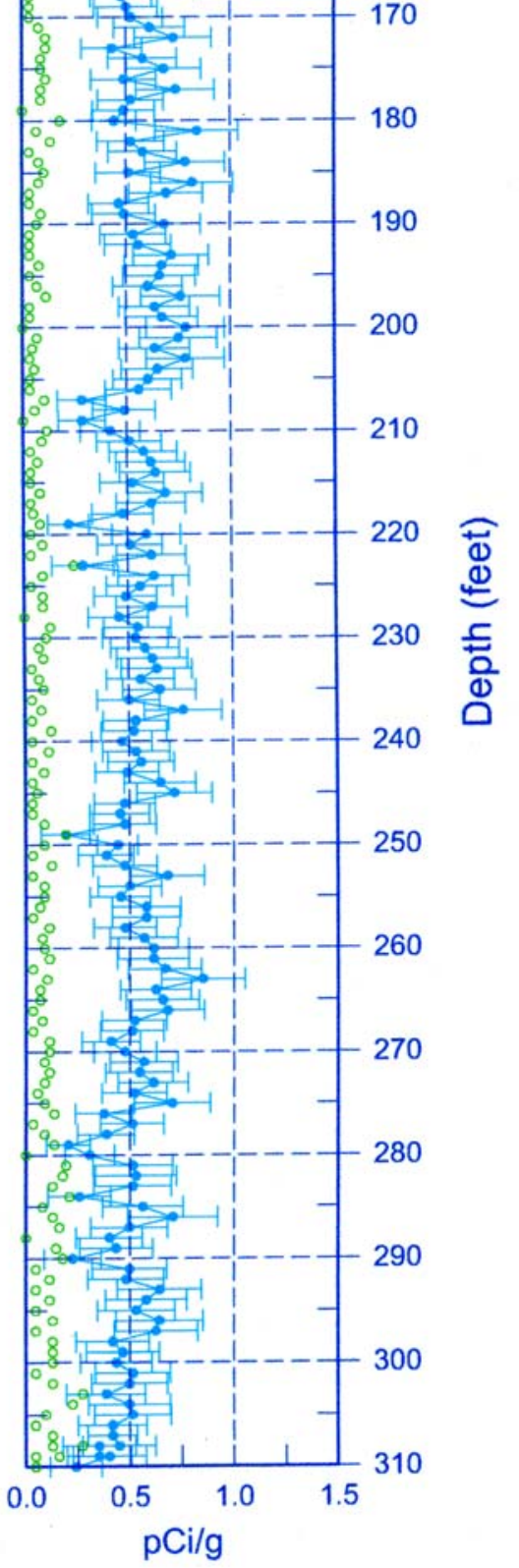

Last Log Date - 07/07/03

C. 6 


\section{C-4122}

Natural Gamma Logs

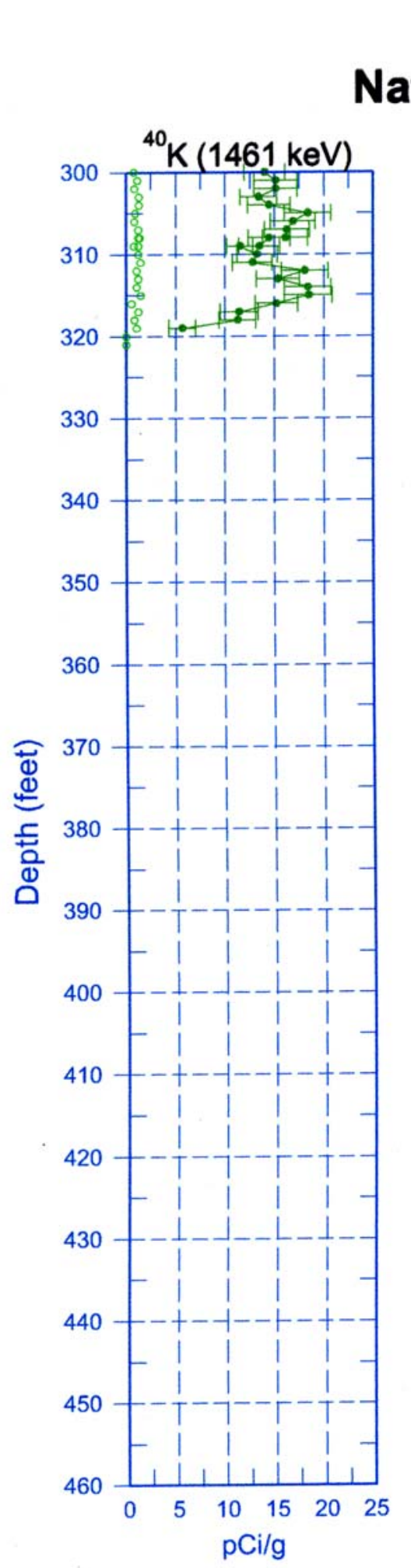

Zero Reference $=$ Ground Surface

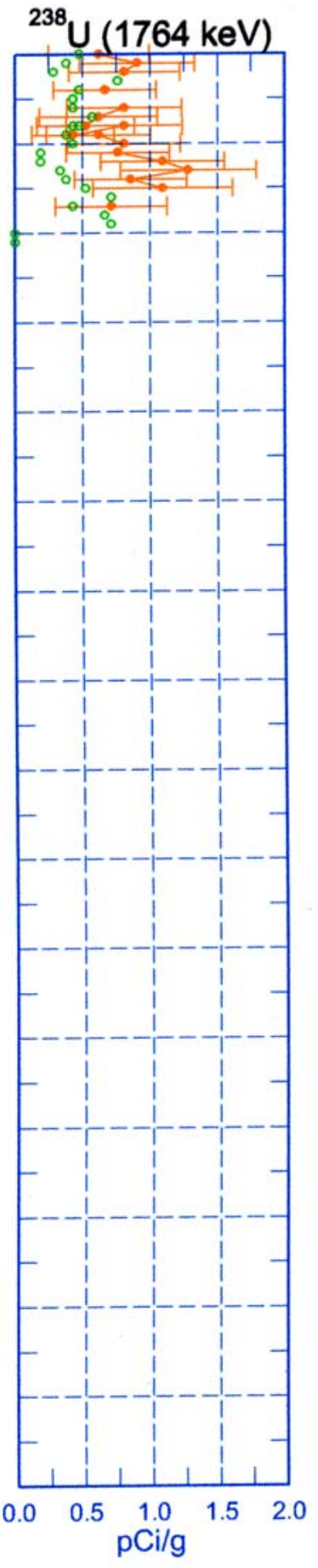

MDL

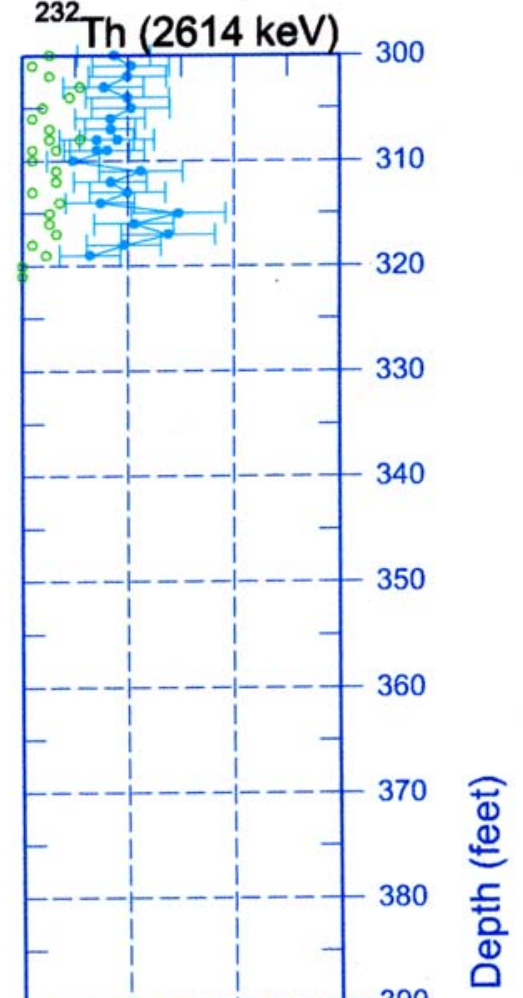

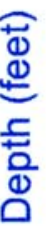

C.7 


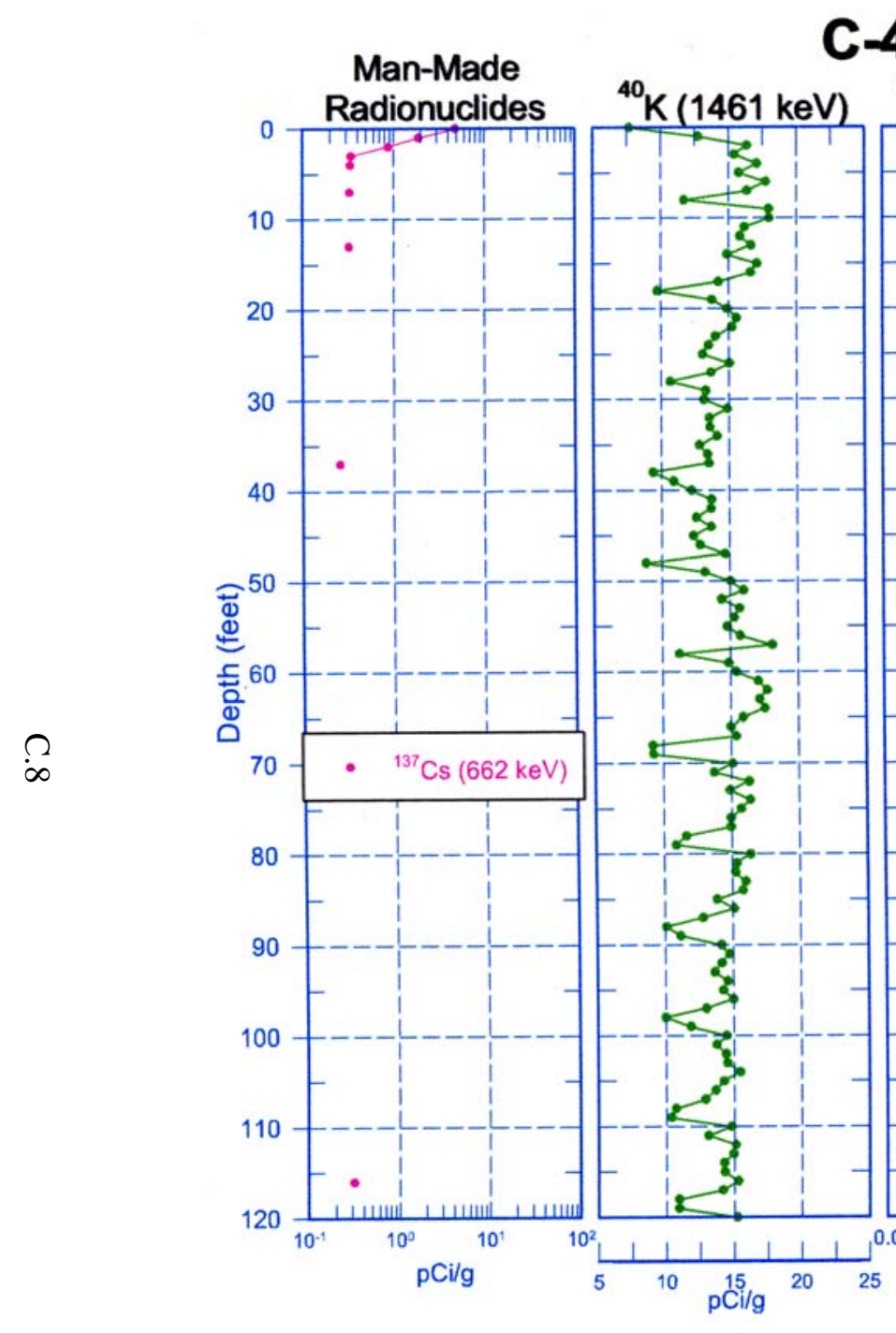

C-4122 Combination Plot

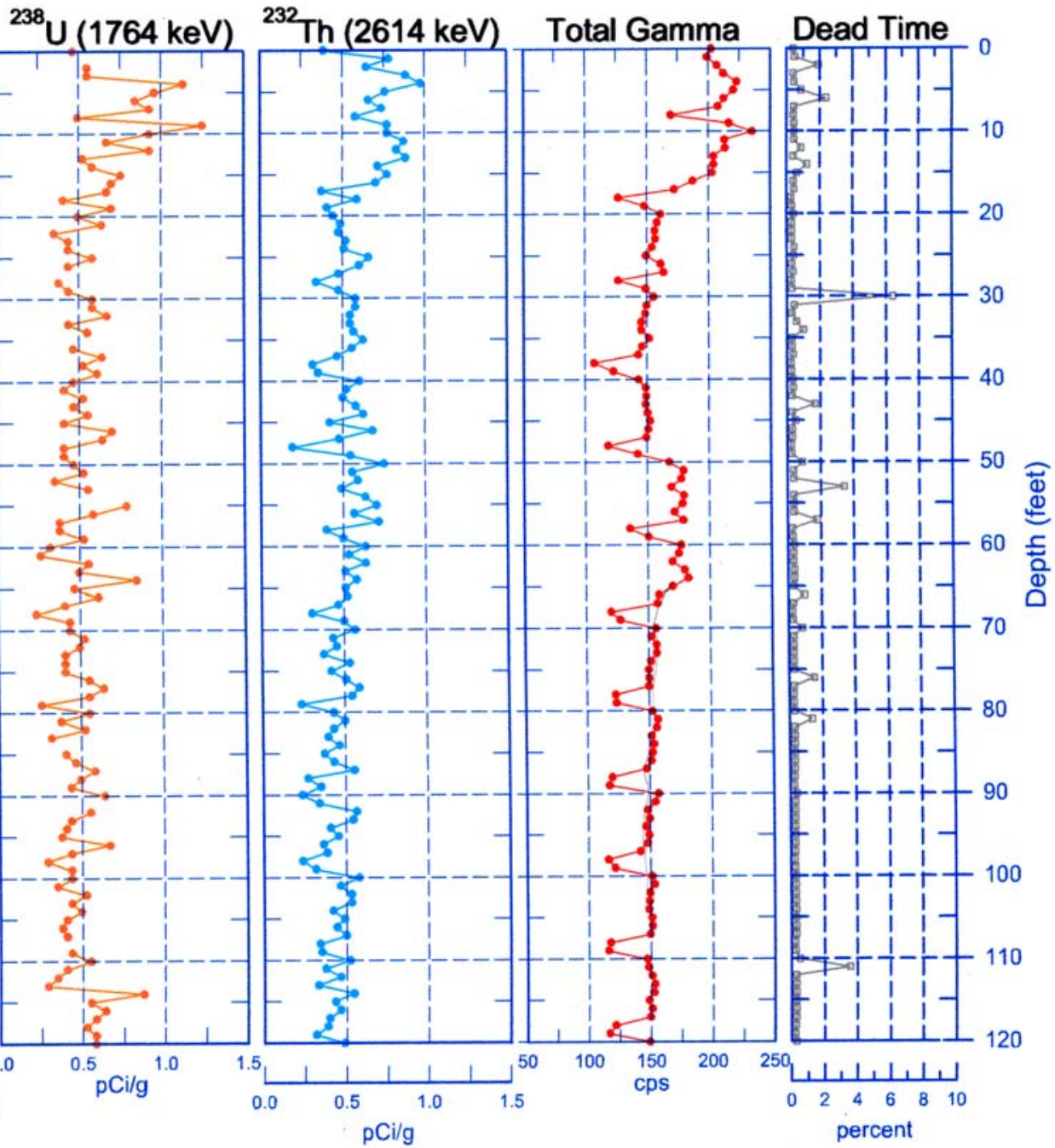

Zero Reference $=$ Ground Surface 


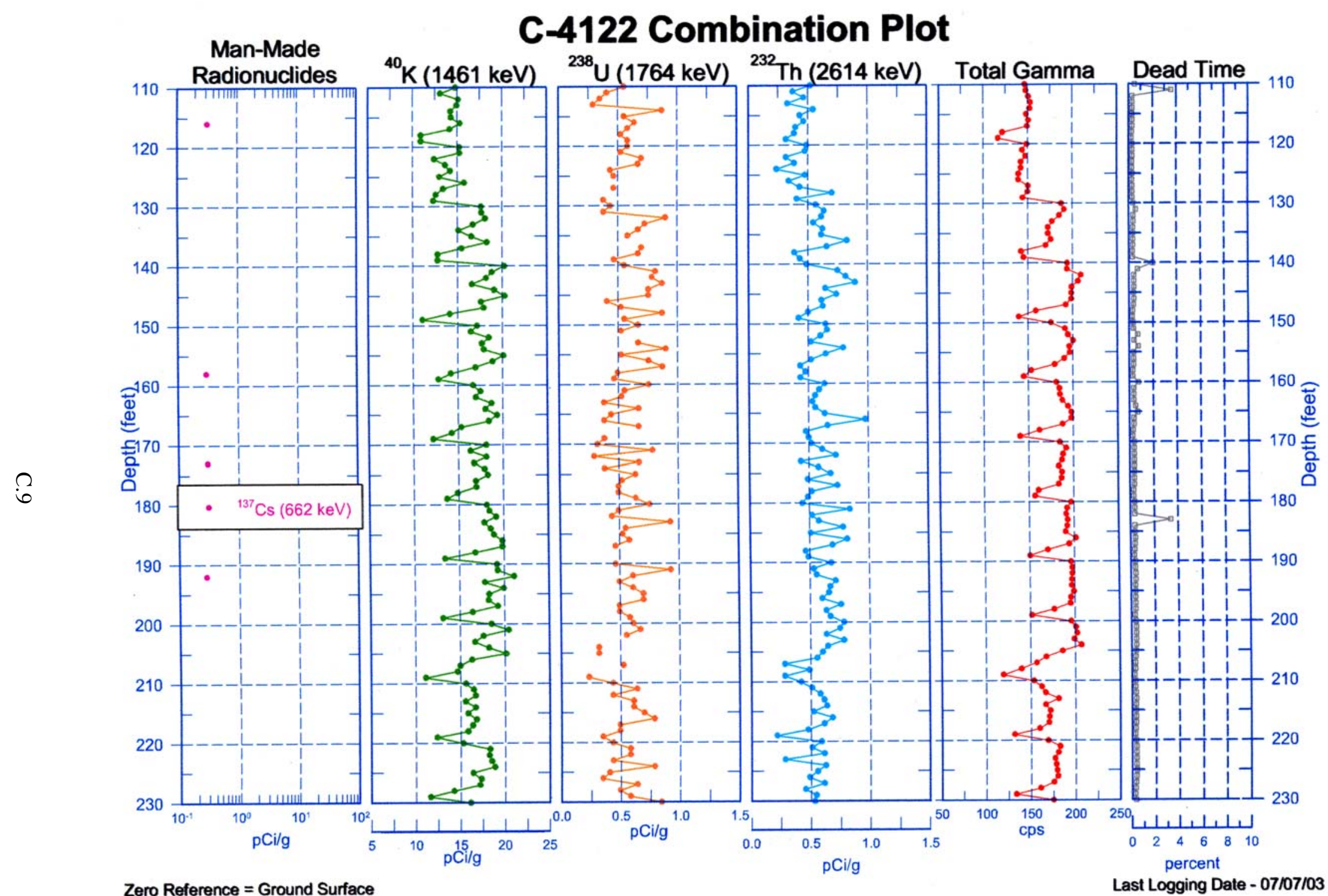




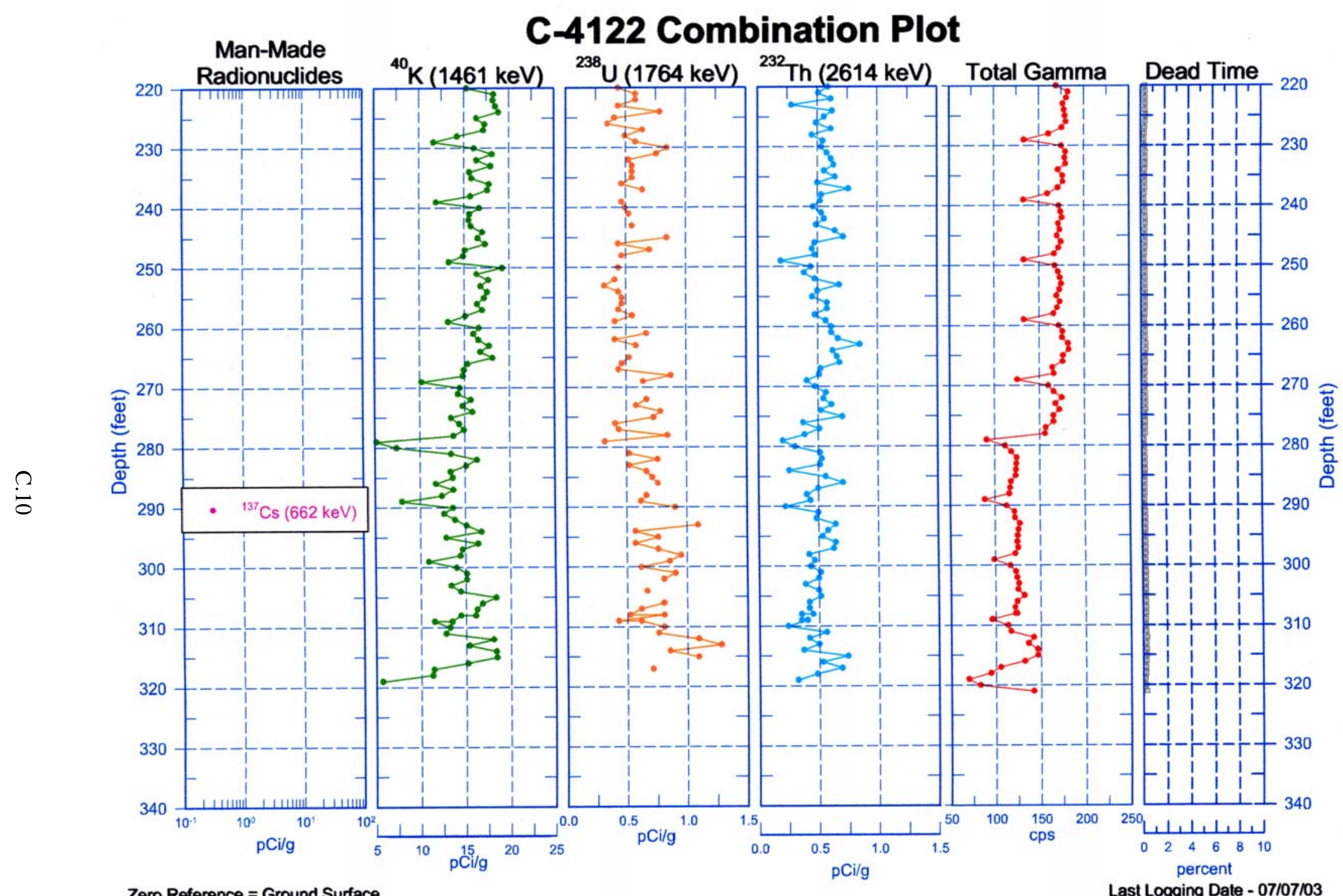




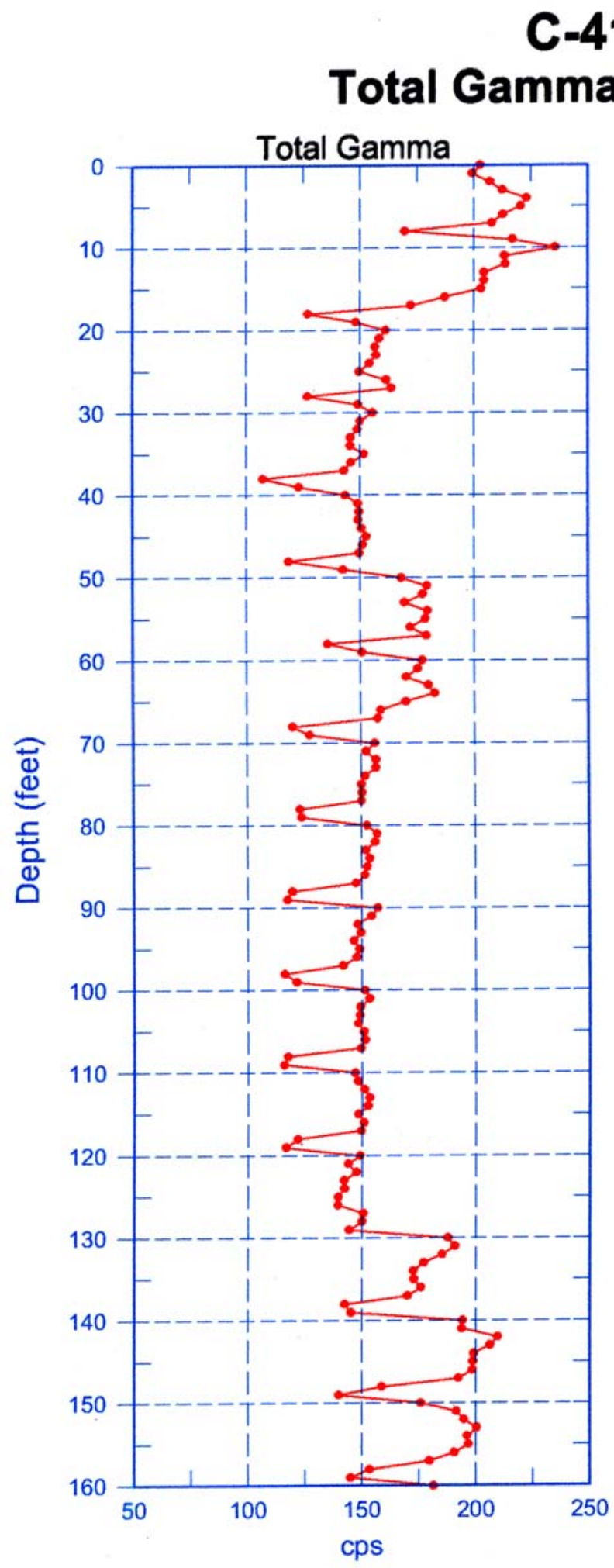

Reference - Ground Surface

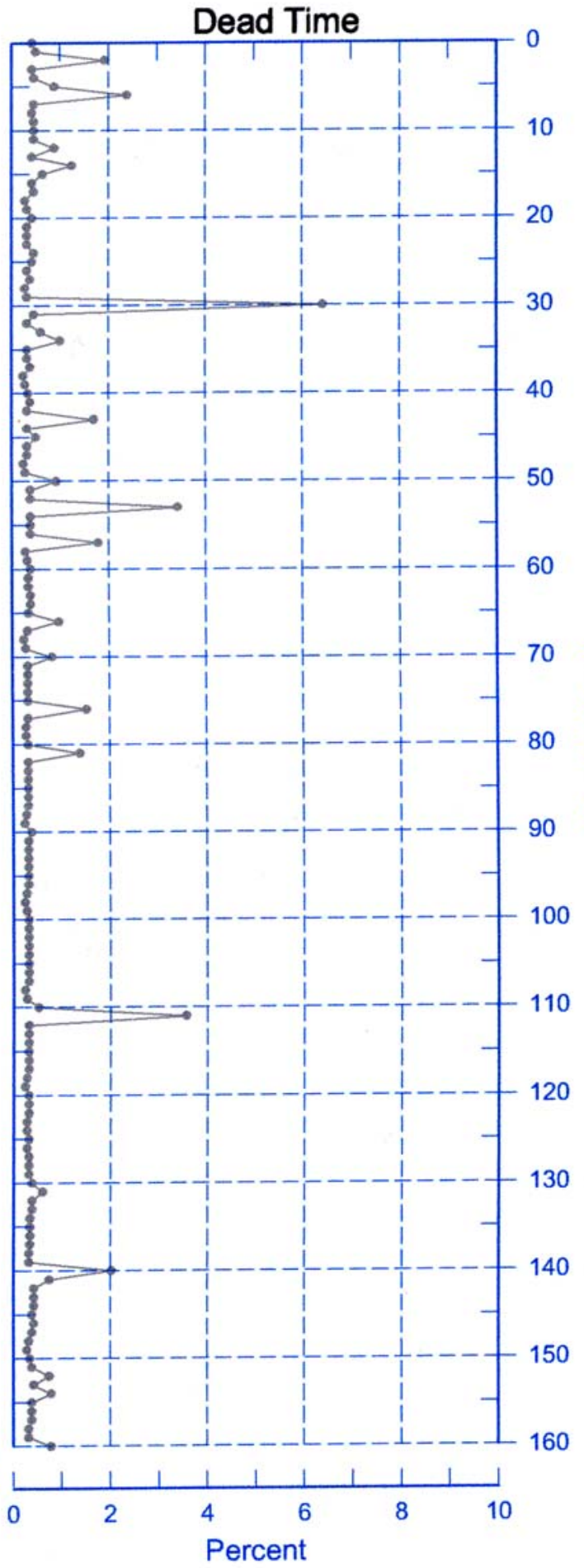

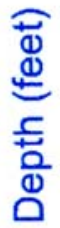

C.11 


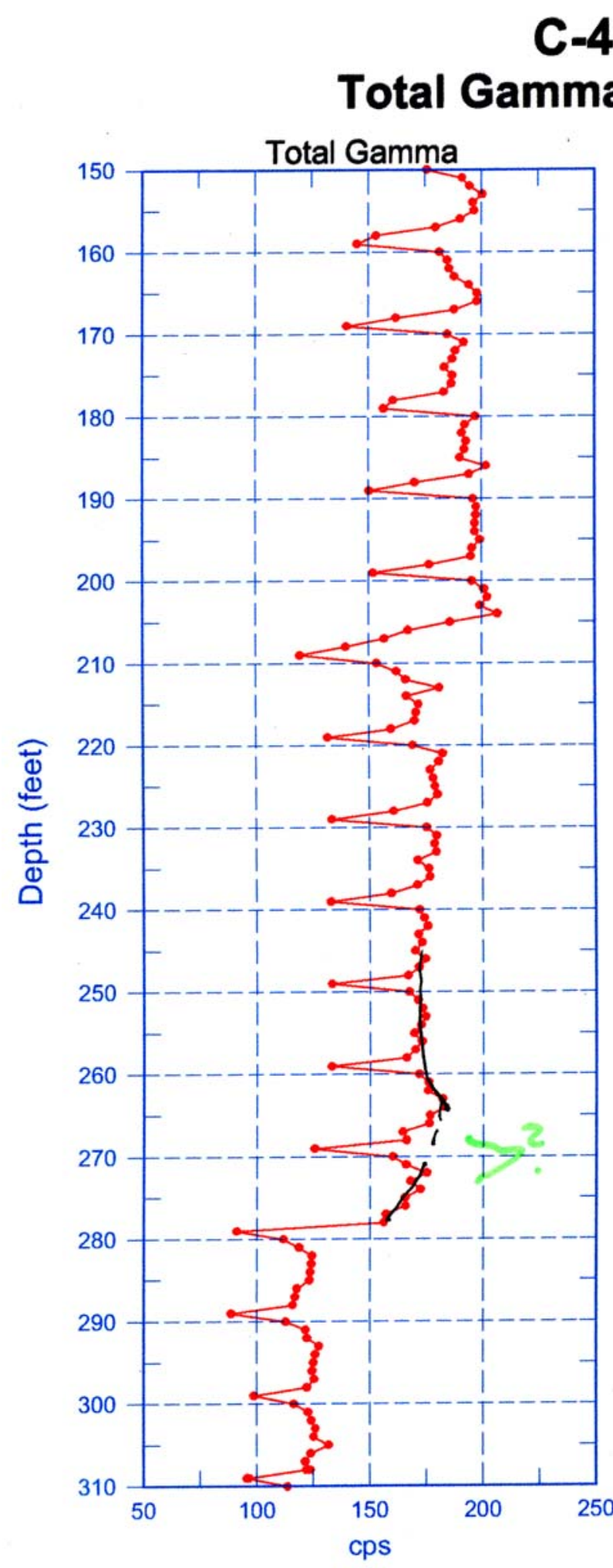

Reference - Ground Surface

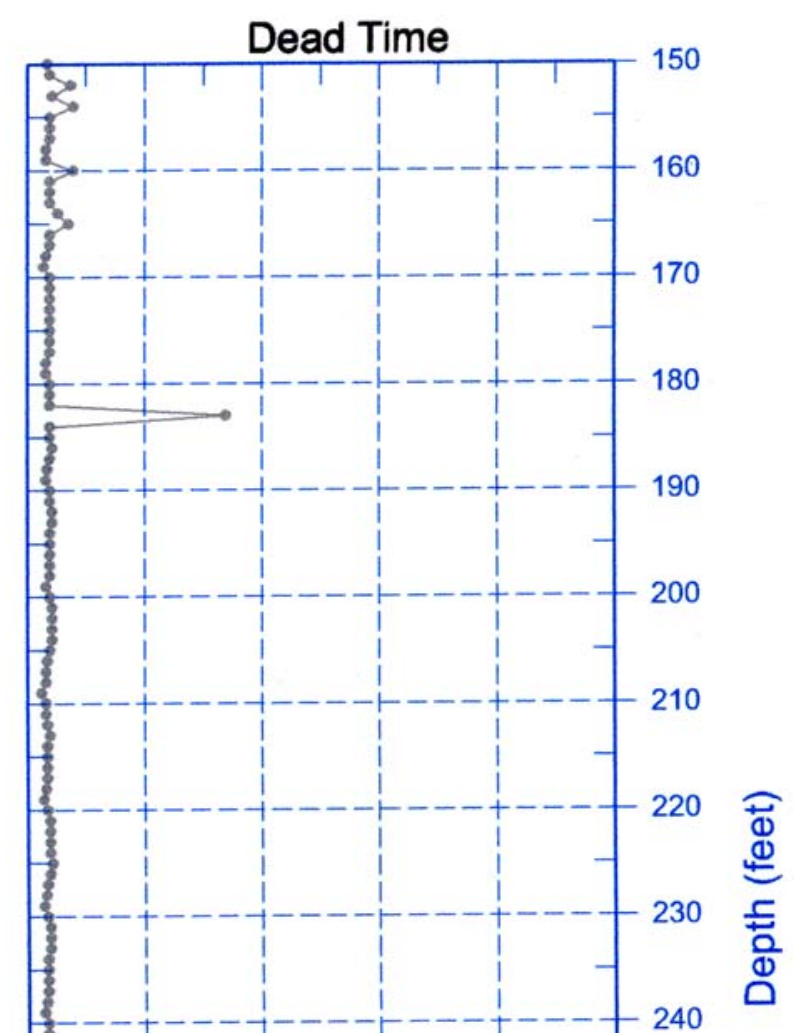

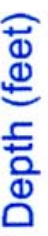




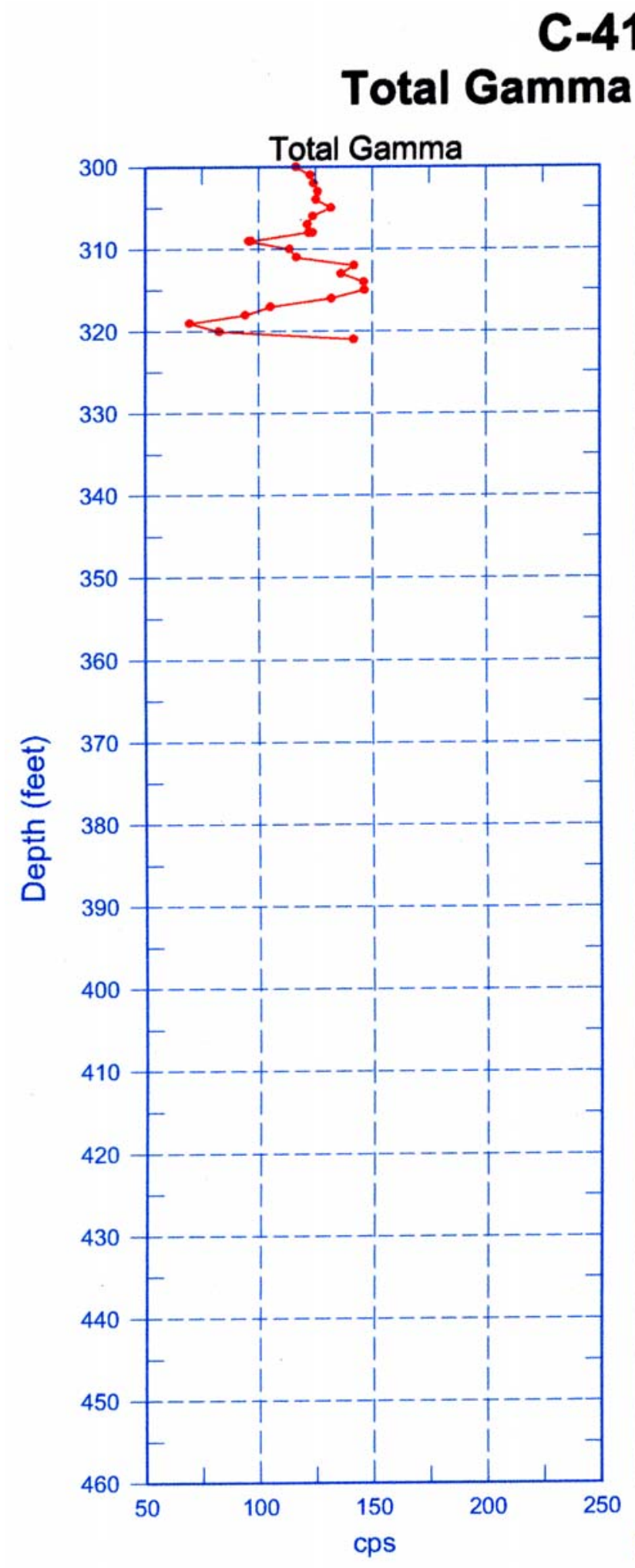

Reference - Ground Surface

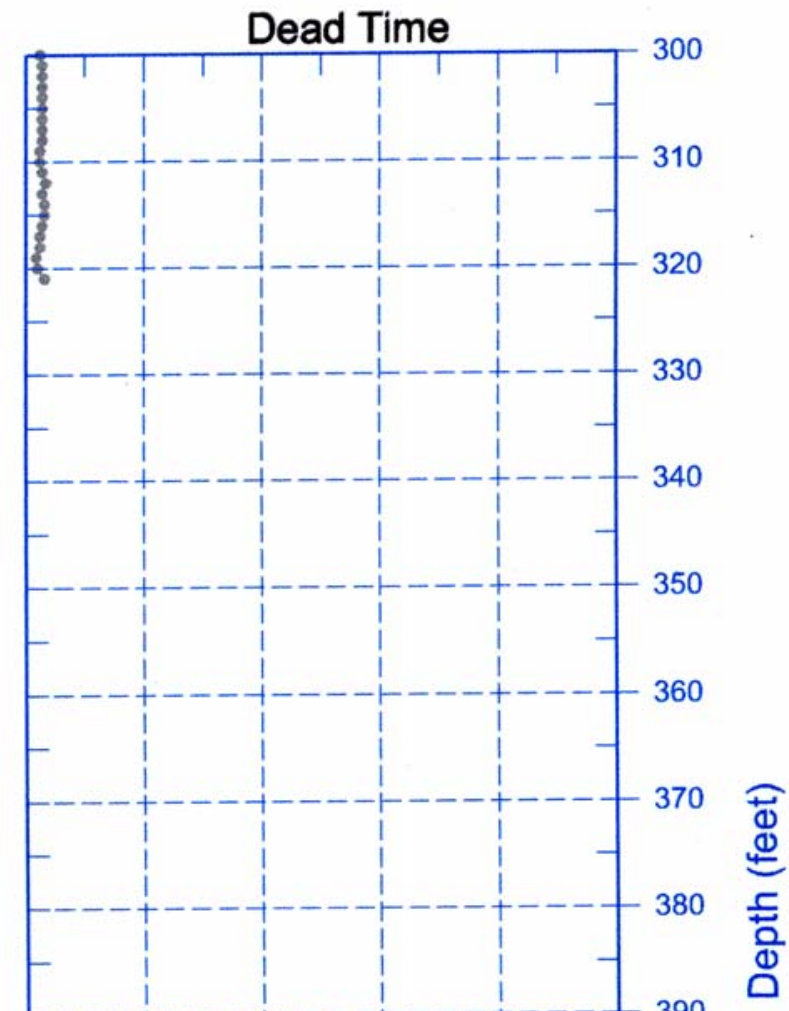

$-390$

400

410

420

430

440

450

460

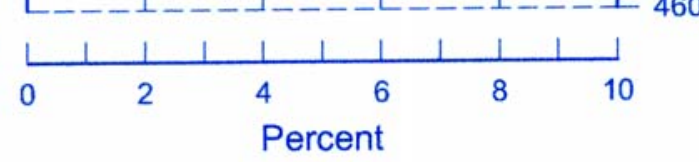

Last Log Date - 07/07/03 


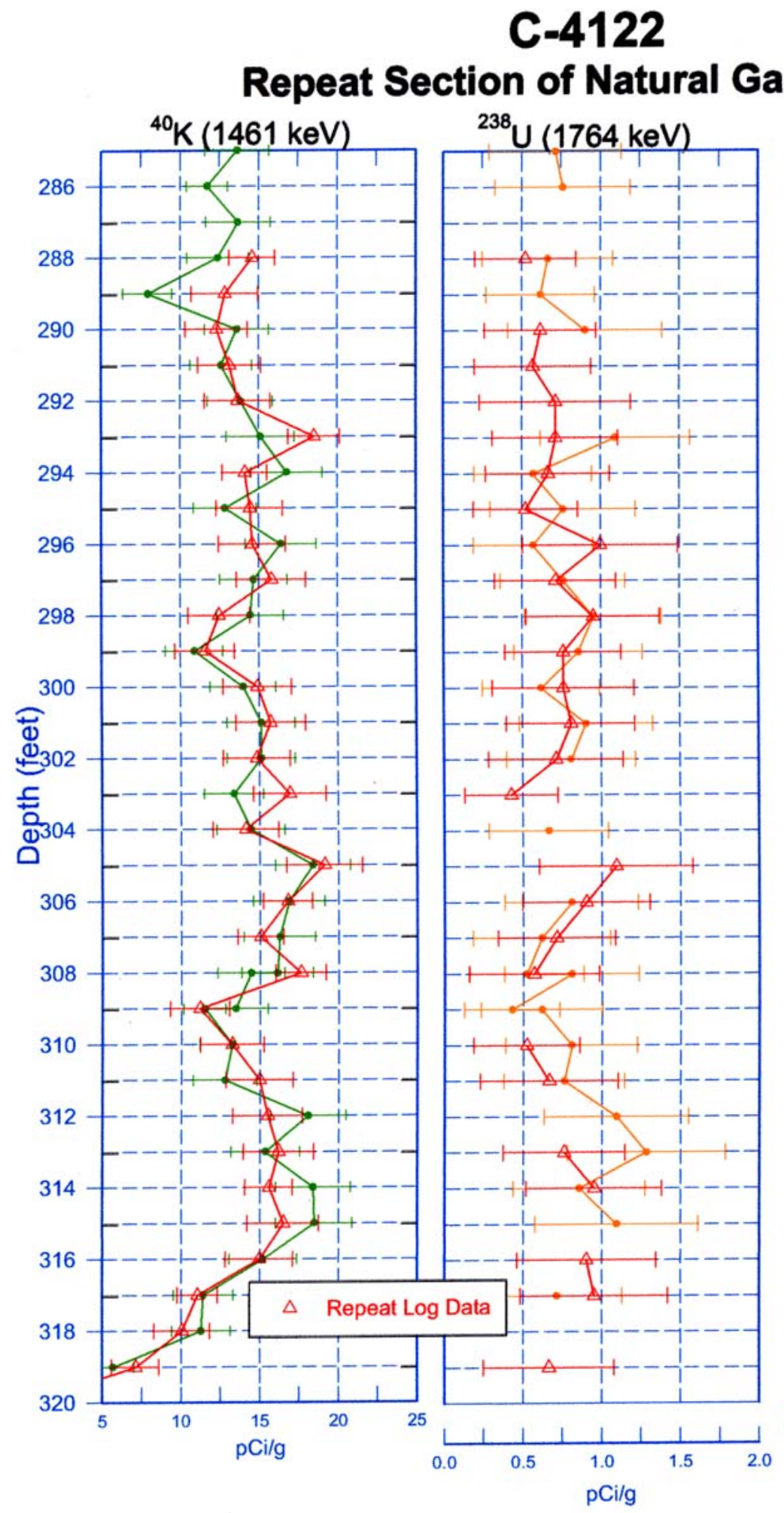

Gamma Logs

${ }^{232}$ Th (2614 keV)

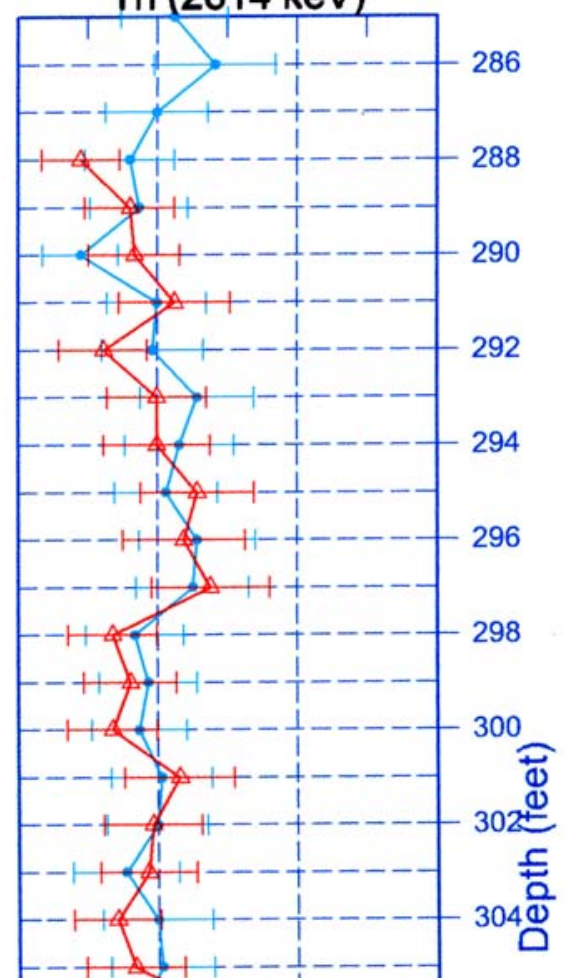

Zero Reference $=$ Ground Surface

Last Log Date - 07/07/03

C.14 


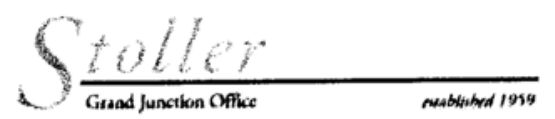

\section{C-4123 \\ Log Data Report}

\section{Borehole Information:}

\begin{tabular}{|c|c|c|c|c|c|}
\hline Borehole: & $\overline{C-4123}$ & & \multicolumn{3}{|c|}{ West of A Tank Farm } \\
\hline \multicolumn{2}{|c|}{ Coordinates (WA st Plane) } & GWL'(it): & 288 & GWL Dato: & $07 / 11 / 03$ \\
\hline $\begin{array}{c}\text { North } \\
\text { (estimated) } \\
138140\end{array}$ & $\begin{array}{c}\text { East } \\
\text { (eatimated) } \\
572265\end{array}$ & $\begin{array}{c}\text { Drill Dato } \\
07 / 03\end{array}$ & $\begin{array}{l}\text { Ground Lovel } \\
\text { Elevation } \\
\text { Not available }\end{array}$ & $\begin{array}{c}\text { Total Depth (it) } \\
328.0\end{array}$ & $\begin{array}{c}\text { Type } \\
\text { Becker }\end{array}$ \\
\hline
\end{tabular}

\section{Casing Information:}

\begin{tabular}{|c|c|c|c|c|c|c|}
\hline Casin' Type & Stickup (fi) & $\begin{array}{l}\text { Outer } \\
\text { Diameter } \\
\text { (in.) }\end{array}$ & $\begin{array}{l}\text { Inside } \\
\text { Diameter } \\
\text { (in.) }\end{array}$ & $\begin{array}{l}\text { Thickness } \\
\text { (in.) }\end{array}$ & Top $(t)$ & Bottom (t) \\
\hline Threaded Steel & 2.65 & 9.0 & 8.0 & 0.50 & +2.65 & 328.0 \\
\hline Steel Tubing & 3.1 & 6.24 & 6.0 & 0.125 & +3.1 & 328.0 \\
\hline
\end{tabular}

\section{Borehole Notes:}

The casing dimensions are derived from published values for Becker drill casing. Casing thicknesses at the joints are $0.875 \mathrm{in}$. and $0.240 \mathrm{in}$. for the 8 -in. and 6-in. casings, respectively. The total depth of the borehole was provided by the driller. The well site geologist provided the depth to water. Borehole coordinates were provided by Fluor Hanford's person in charge and are estimates. Ground level elevation was not available. Logging data acquisition is referenced to the ground surface.

\section{Logoing Equipment Information:}

\begin{tabular}{|c|c|c|c|}
\hline Logging 8yatem: & Gamma 2A & & $\begin{array}{ll}\text { Type: } & \text { SGLS (35\%) } \\
\text { SN: 34TP11019B }\end{array}$ \\
\hline Callbration Date: & $01 / 03$ & Callbration Reference: & GJ0-2003-418-TAC \\
\hline & & Lorfin' Procedure: & MAC-HGLP 1.6.5, Rev. 0 \\
\hline
\end{tabular}

\section{Spectral Gamma Logging System (SGLS) Log Run Information:}

\begin{tabular}{|c|c|c|c|c|c|}
\hline Lo\% Run & 1 & 2 & 3 & 4 Repeat & \\
\hline Date & $07 / 12 / 03$ & $07 / 14 / 03$ & $07 / 15 / 03$ & $07 / 15 / 03$ & \\
\hline Logging Engineer & Spatz & Spatz & Spatz & Spatz & \\
\hline Start Depth (fi) & 105.0 & 328.0 & 163.0 & 105.0 & \\
\hline Finish Depth (ft) & 0.0 & 162.0 & 104.0 & 72.0 & \\
\hline Count Time (sec) & 200 & 200 & 200 & 200 & \\
\hline Live/Real & $\mathbf{R}$ & $\mathbf{R}$ & $\mathbf{R}$ & $\mathbf{R}$ & \\
\hline Shield (Y/N) & $\mathbf{N}$ & $\mathbf{N}$ & $\mathrm{N}$ & $\mathbf{N}$ & \\
\hline MSA Interval (ft) & 1.0 & 1.0 & 1.0 & 1.0 & \\
\hline $\mathrm{ft} / \mathrm{min}$ & $N / A^{2}$ & N/A & N/A & N/A & \\
\hline Pre-Verfication & BA209CAA & BA210CAB & BA211CAB & BA211CAB & \\
\hline Start File & BA209000 & BA210000 & BA211000 & BA211058 & \\
\hline
\end{tabular}

\section{Page 1}




\begin{tabular}{|l|l|l|l|l|l|}
\hline Log Run & 1 & 2 & 3 & 4 Repeat & \\
\hline Finish File & BA209105 & BA210166 & BA211059 & BA211091 & \\
\hline Post-Verification & BA209CAA & BA210AA & BA211CAA & BA211CAA & \\
\hline $\begin{array}{l}\text { Depth Return Error } \\
\text { (in.) }\end{array}$ & 0 & 0 & Not applicable & +1 & \\
\hline Comments & $\begin{array}{l}\text { Fine-gain } \\
\text { adjustment } \\
\text { made after } \\
\text { files -076 and } \\
-095 .\end{array}$ & $\begin{array}{l}\text { No fine-gain } \\
\text { adjustment. }\end{array}$ & $\begin{array}{l}\text { No fine-gain } \\
\text { adjustment. }\end{array}$ & $\begin{array}{l}\text { No fine-gain } \\
\text { adjustment. }\end{array}$ & \\
\hline
\end{tabular}

\section{Logging Operation Notes:}

Spectral gamma logging was performed in this borehole between July 12 and 15, 2003. Logging was conducted with a centralizer on the sonde and measurements are referenced to ground surface. A repeat section was collected in this borehole to evaluate system performance.

\section{Analysis Notes:}

\begin{tabular}{|l|l|l|l|l|l|}
\hline Analyst: & Henwood & Date: & $07 / 21 / 03$ & Reference: & GJO-HGLP 1.6.3, Rev. 0 \\
\hline
\end{tabular}

Pre-run and post-run verifications for the logging system were performed before and after data acquisition. Acceptance criteria were met except for file numbers BA209CAB and BA210CAB. The total counts per second (cps) were exceeded for the 2614- and 1461-keV energy peaks for files BA209CAB and BA210CAB, respectively. The percent change between the before and after verification (i.e., files BA211CAB and BA211CAA, log runs 3 and 4) for the 2614-keV energy peak was 22 percent, which exceeds the criterion of 10 percent. After examination of individual spectra, the logging sonde appeared to have functioned normally and the data are provisionally accepted.

A combined casing correction for 0.625 -in.-thick casing was applied throughout the borehole for both casings. The combined thickness at casing joints is 1.115 in. This thickness results in a significant reduction in gamma activity detection as the detector passes by a casing joint. However, it is not practical to correct individual data points for the effect of casing joints. The influence of the thick joints is apparent on the total gamma and ${ }^{40} \mathrm{~K}$ logs where reduced count rates and concentrations are exhibited at approximately 10 -ft depth intervals.

SGLS spectra were processed in batch mode using APTEC SUPERVISOR to identify individual energy peaks and determine count rates. Concentrations were calculated with an EXCEL worksheet template identified as G2AFEB03.xls using efficiency functions and corrections for casing, water, and dead time as determined from annual calibrations. Dead time corrections are applied where dead times exceed 10.5 percent; no dead times in excess of 10.5 percent were encountered. Correction for water was applied to the data below $288 \mathrm{ft}$.

\section{Log Plot Notes:}

Separate log plots are provided for the man-made radionuclide $\left({ }^{137} \mathrm{Cs}\right)$ detected in the borehole, naturally occurring radionuclides $\left({ }^{40} \mathrm{~K},{ }^{238} \mathrm{U},{ }^{232} \mathrm{Th}\right.$ [KUT] $)$, a combination of man-made, KUT, and dead time, and total gamma plotted with dead time. For each radionuclide, the energy value of the spectral peak used for quantification is indicated. Unless otherwise noted, all radionuclides are plotted in picocuries per gram (pCi/g). The open circles indicate the minimum detectable level (MDL) for each radionuclide. Error bars on each plot represent error associated with counting statistics only and do not include errors associated with the inverse efficiency function, dead time correction, casing corrections, or water corrections. A repeat $\log$ section is also included. 


\section{Results and Interpretations:}

${ }^{137} \mathrm{Cs}$ was the only man-made radionuclide detected in this borehole. ${ }^{137} \mathrm{Cs}$ was detected at a few sporadic locations throughout the borehole near its MDL of approximately $0.2 \mathrm{pCi} / \mathrm{g}$.

The repeat sections indicated good agreement of the naturally occurring KUT.

${ }^{1} \mathrm{GWL}$ - groundwater level

${ }^{2} \mathrm{~N} / \mathrm{A}$ - not applicable

Page 3 


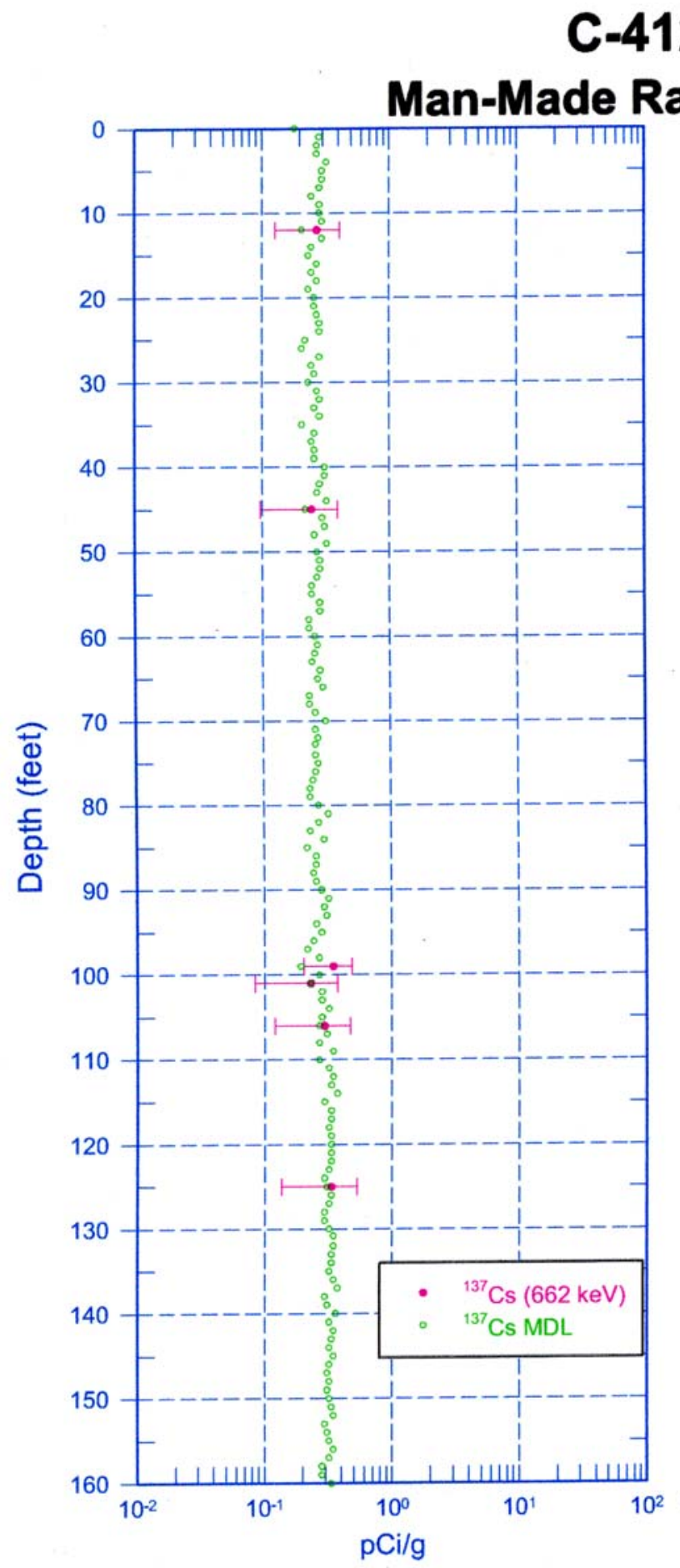

Zero Reference $=$ Ground Surface
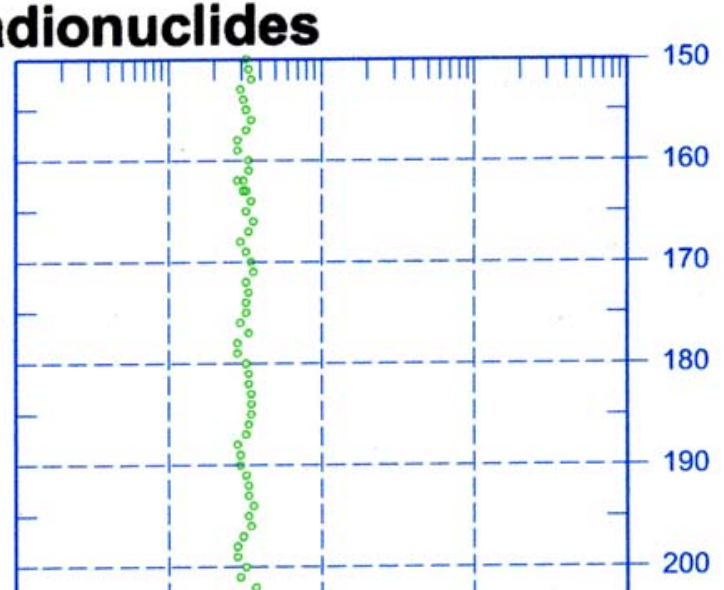

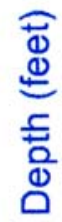
250 260 270 280 290

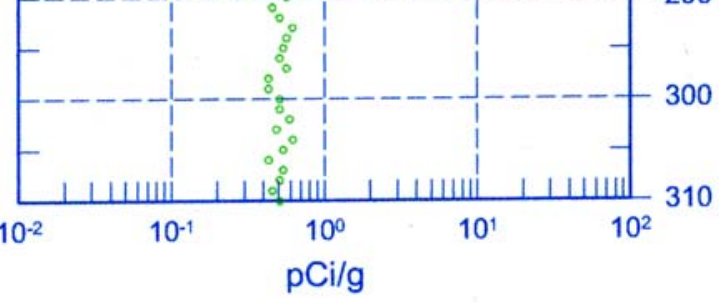

Last Log Date - 07/15/03 


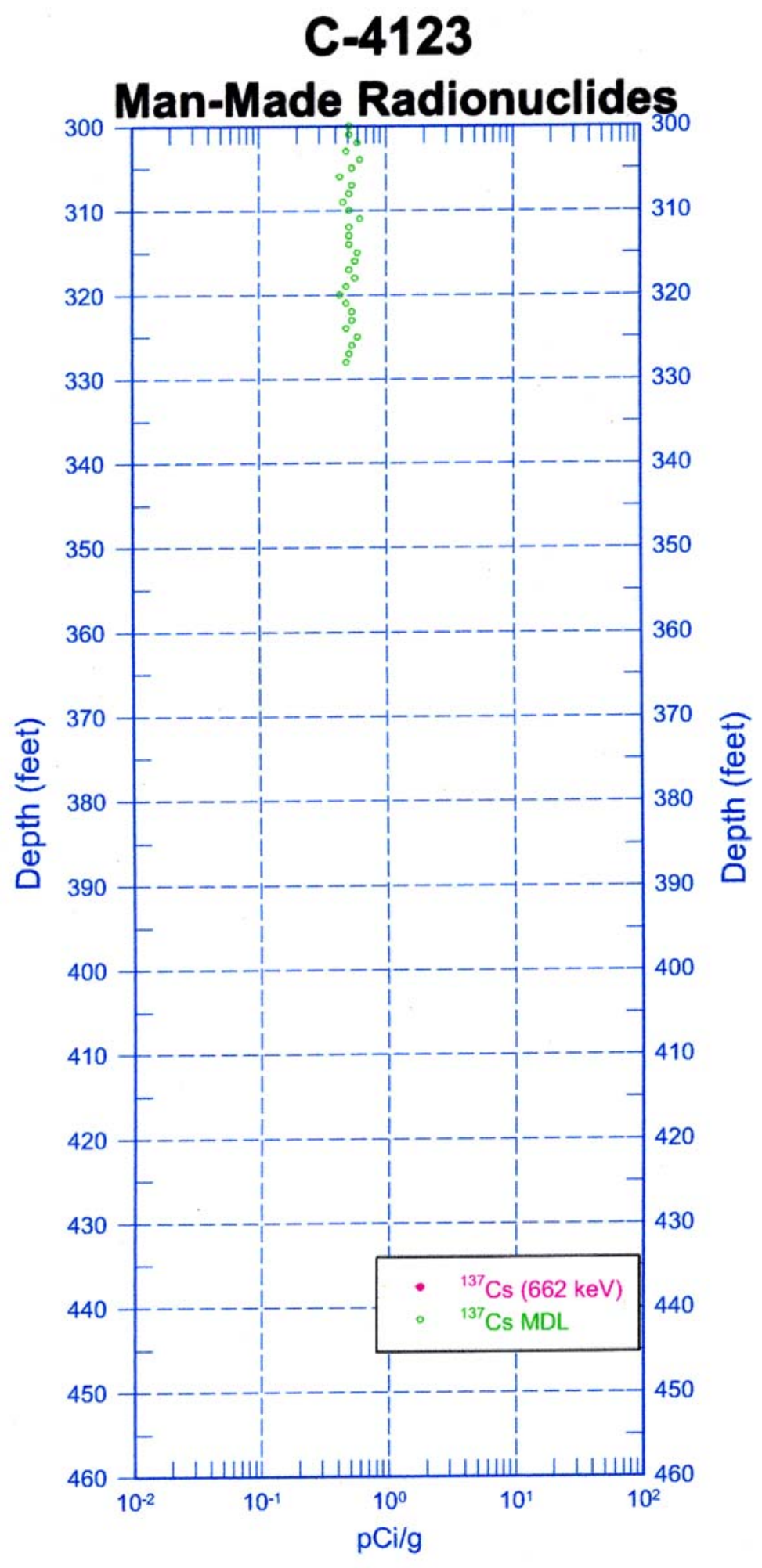

Zero Reference $=$ Ground Surface

Last Log Date - 07/15/03

C.19 


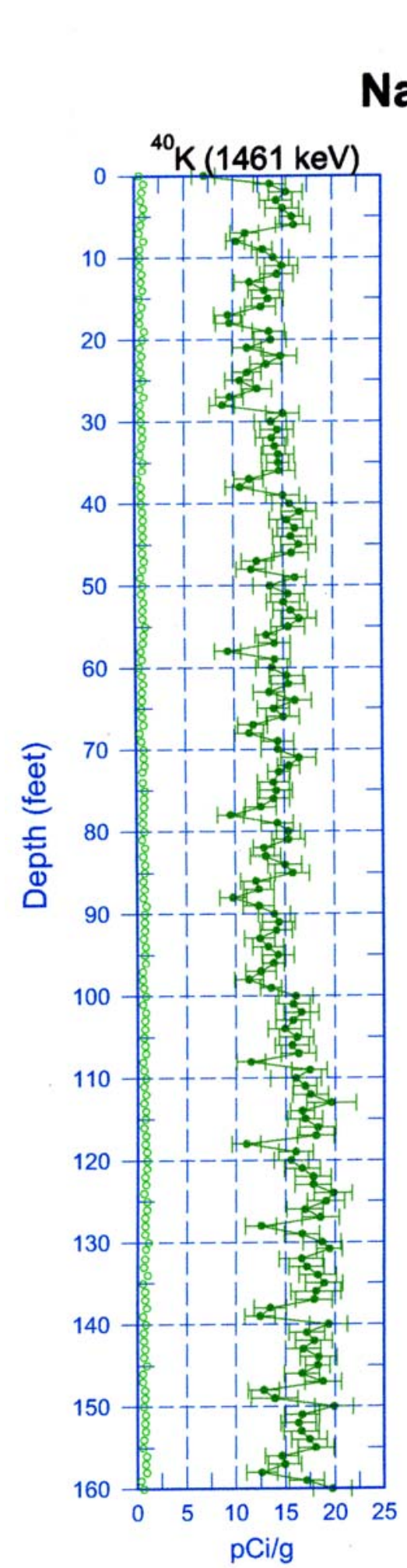

Zero Reference $=$ Ground Surface
C-4123

Natural Gamma Logs
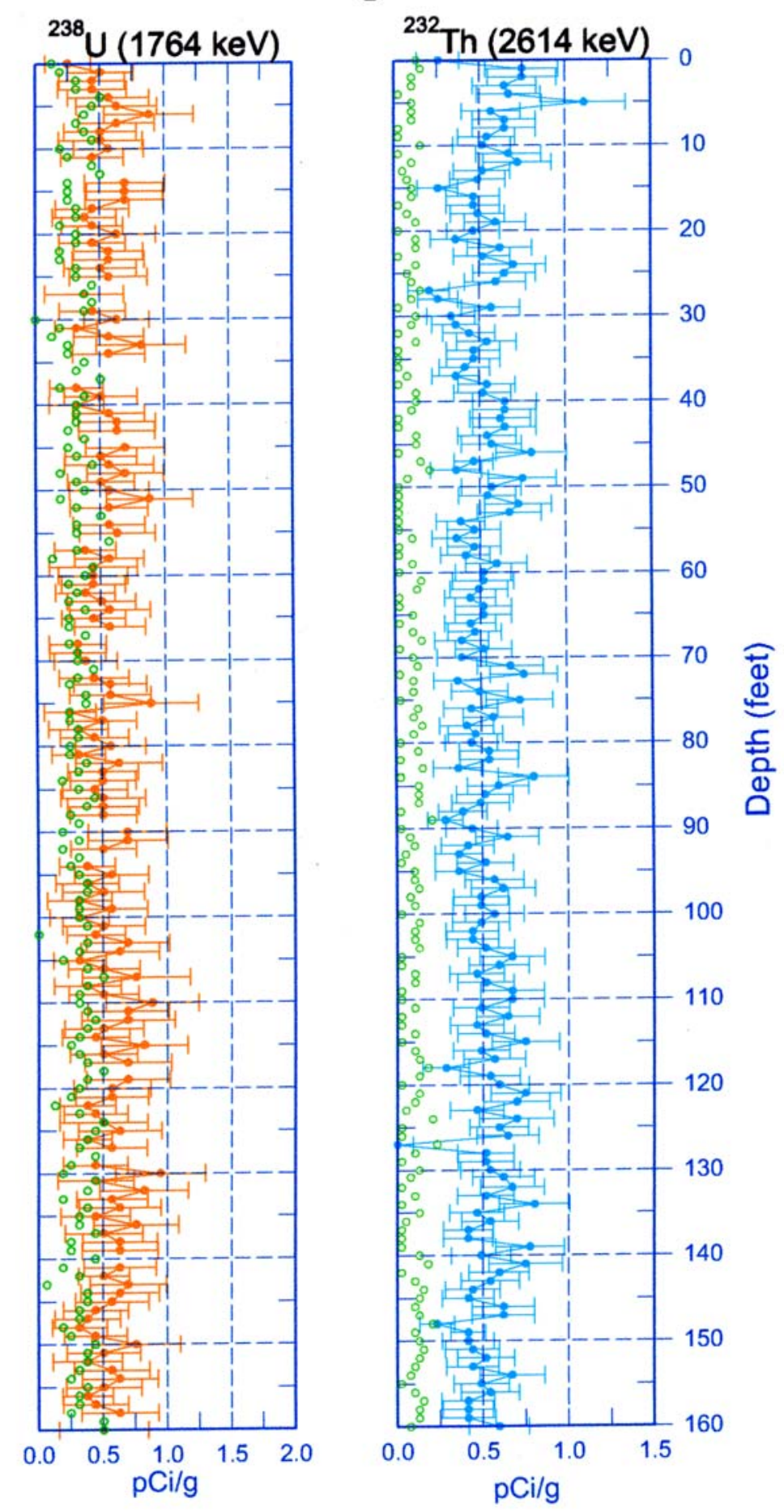

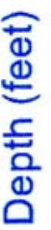




\section{C-4123 \\ Natural Gamma Logs}

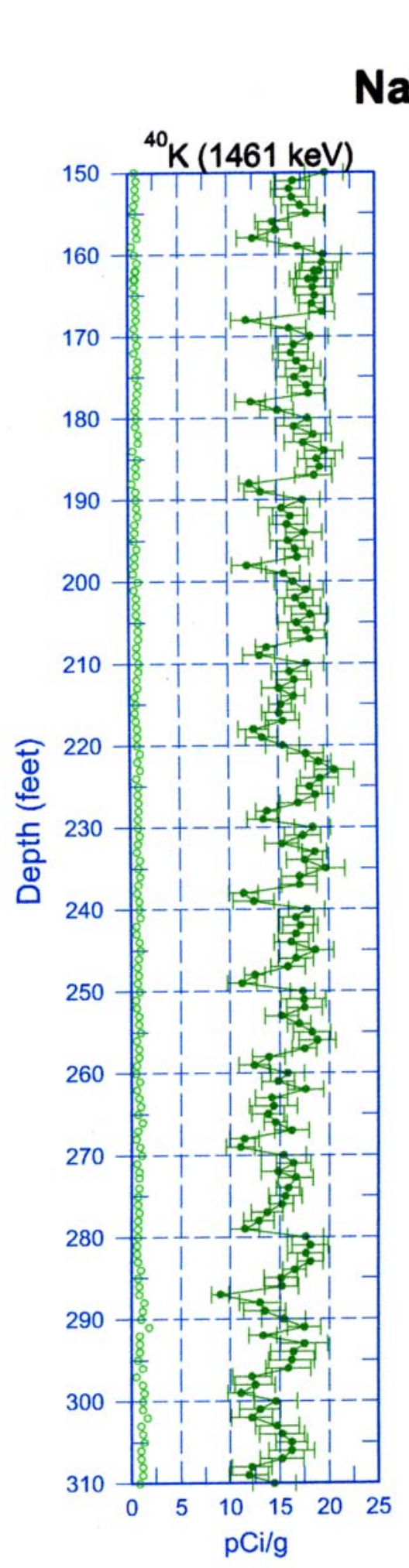

Zero Reference $=$ Ground Surface

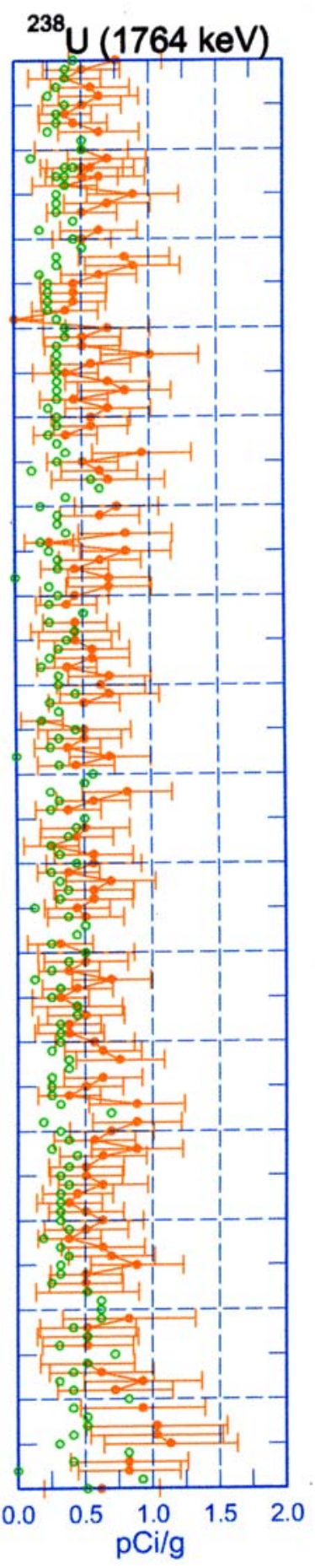

MDL
${ }^{232}$ Th (2614 keV) 150
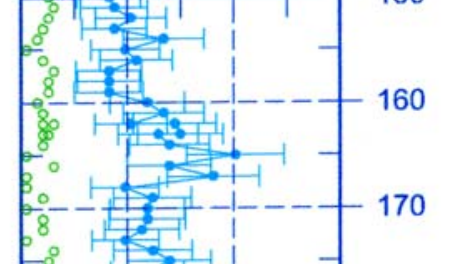

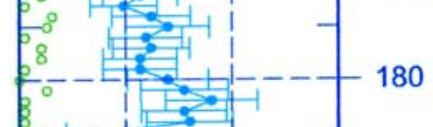

30
$8-1 \frac{1}{3}-1$

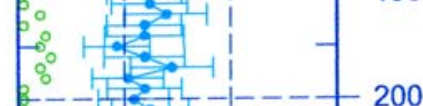

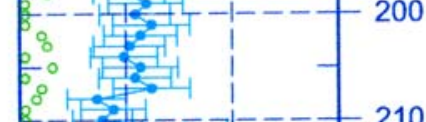

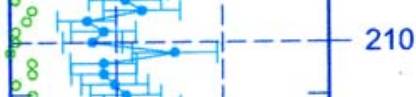

3०0.

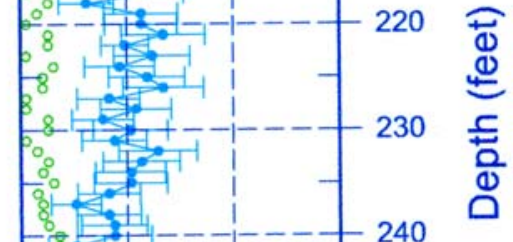
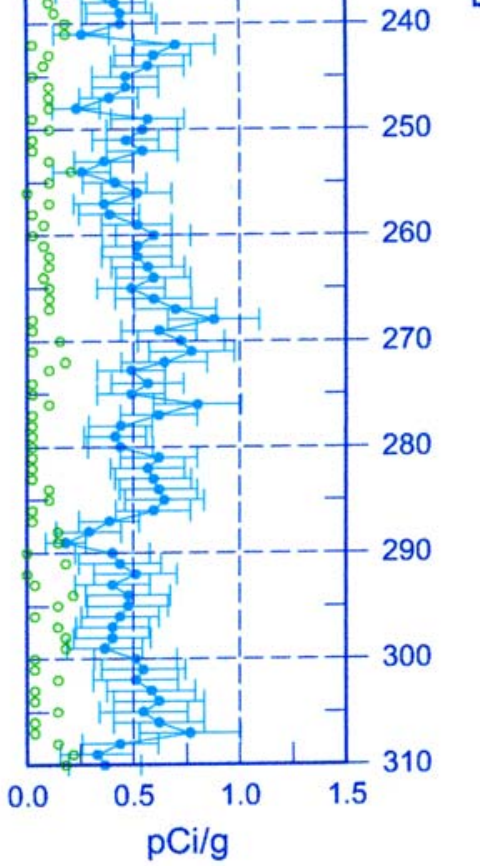

Last Log Date - 07/15/03

C. 21 


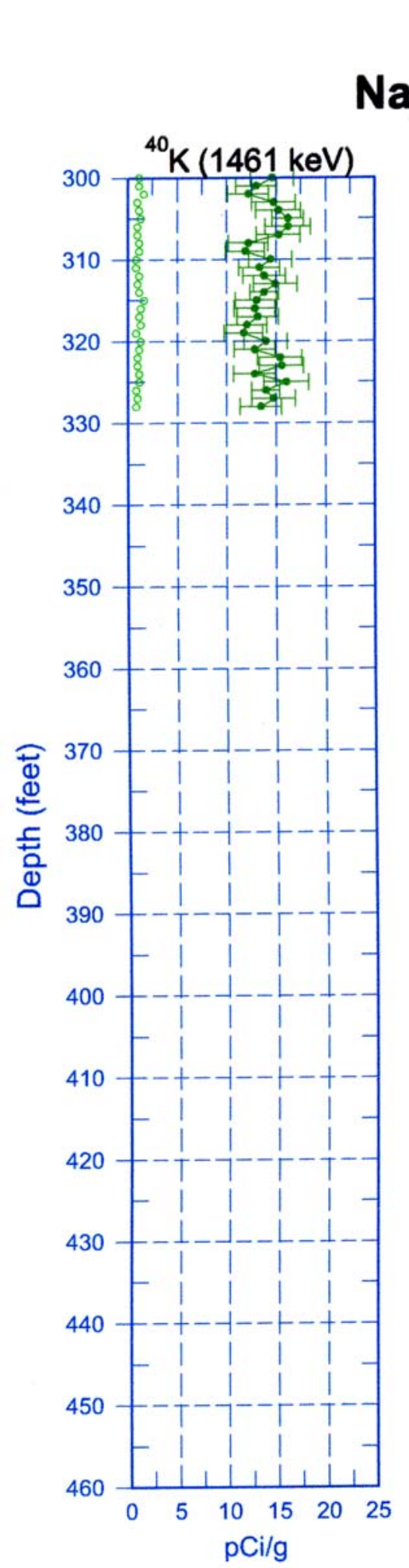

Zero Reference $=$ Ground Surface

C-4123

Natural Gamma Logs

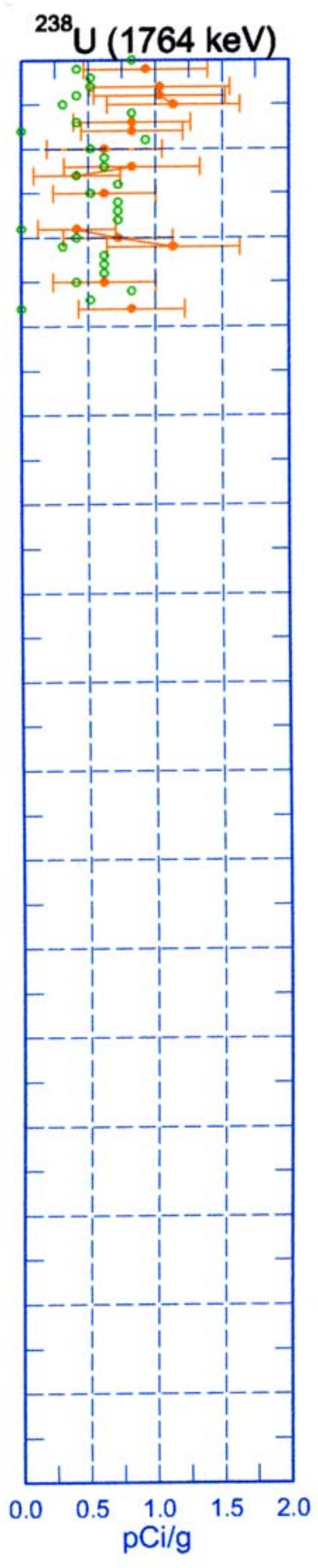

- MDL
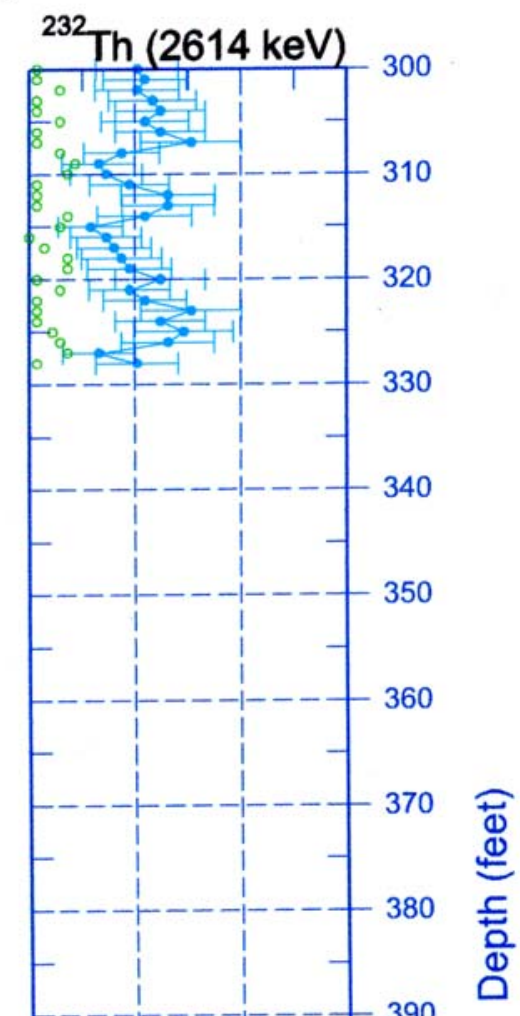

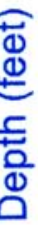



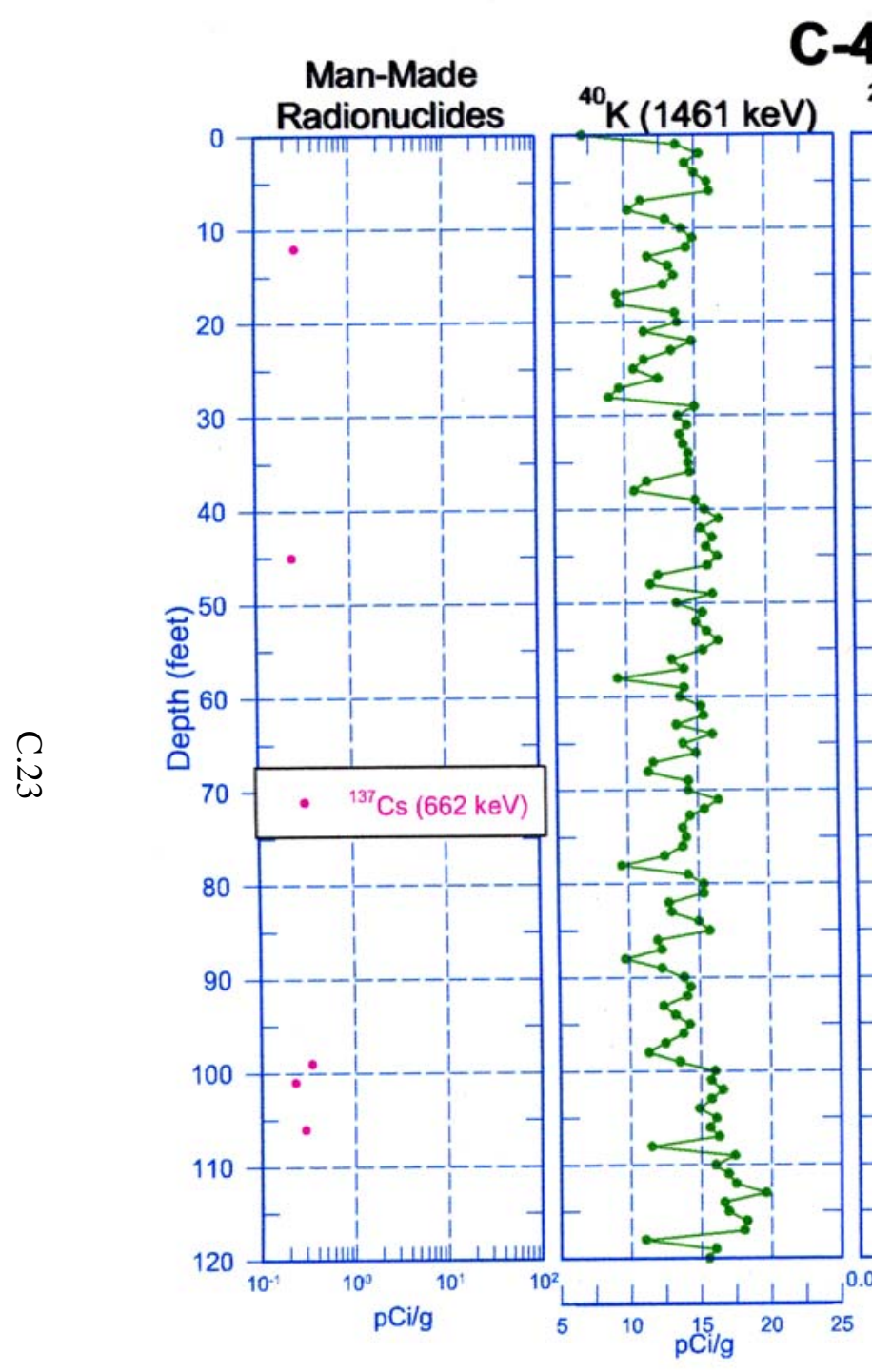

C-4123 Combination Plot

${ }^{238} \mathrm{U}(1764 \mathrm{keV}){ }^{232} \mathrm{Th}(2614 \mathrm{keV})$

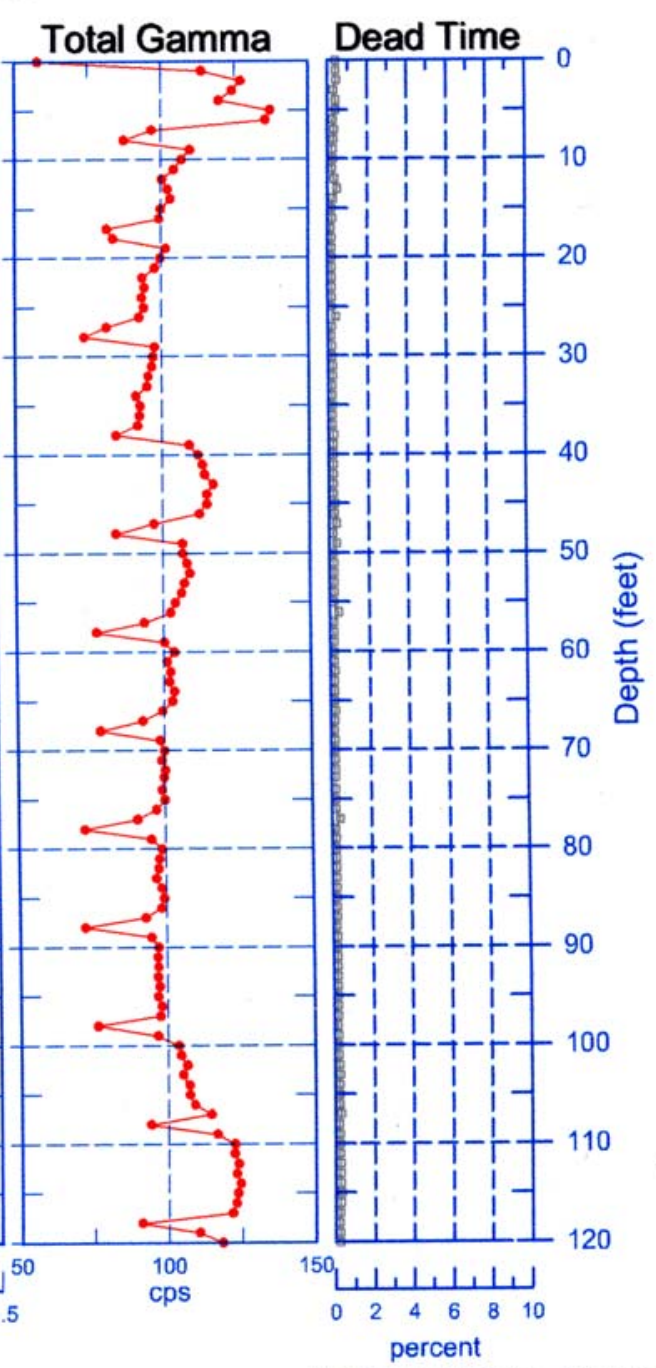

Zero Reference $=$ Ground Surface 

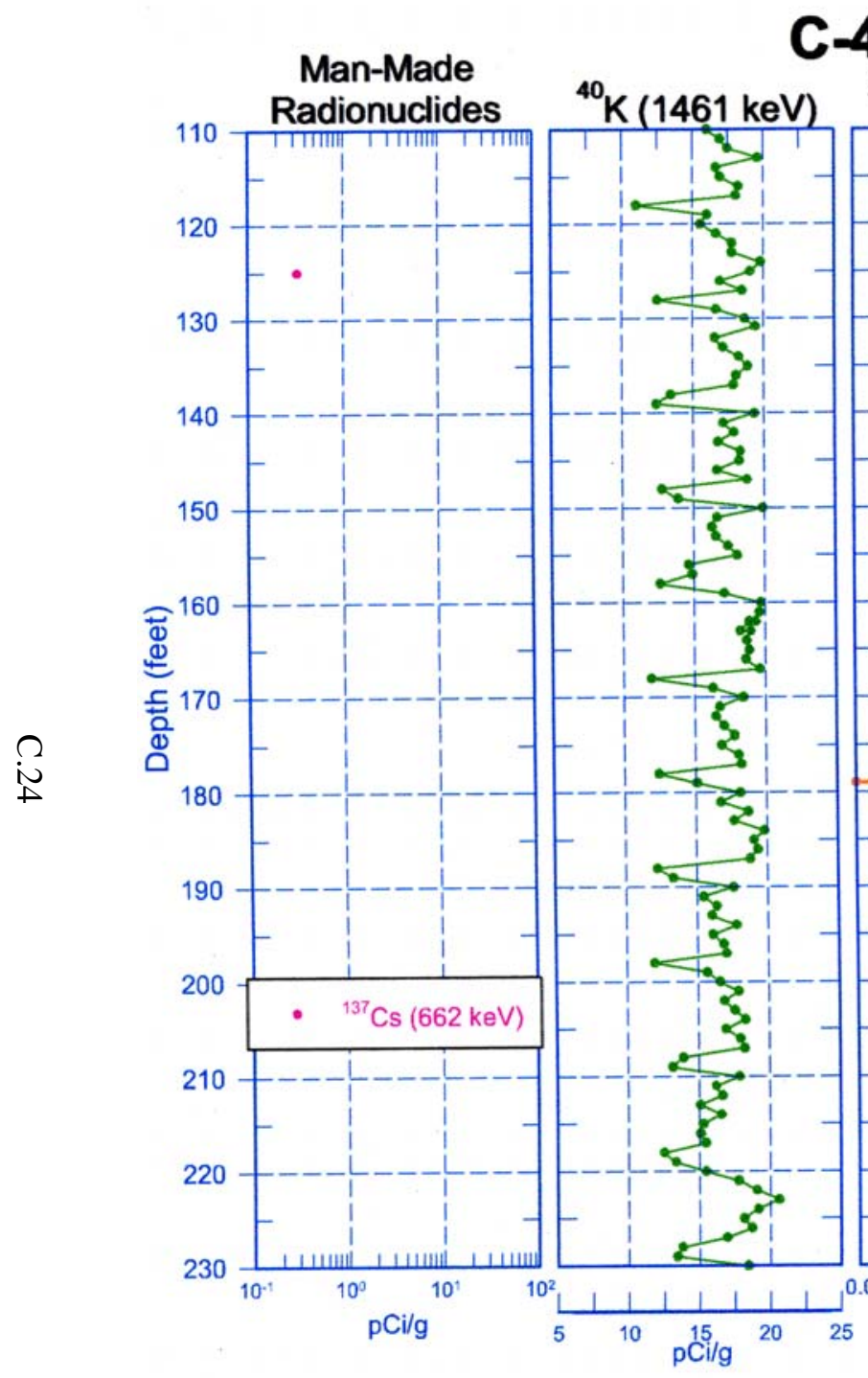

C-4123 Combination Plot

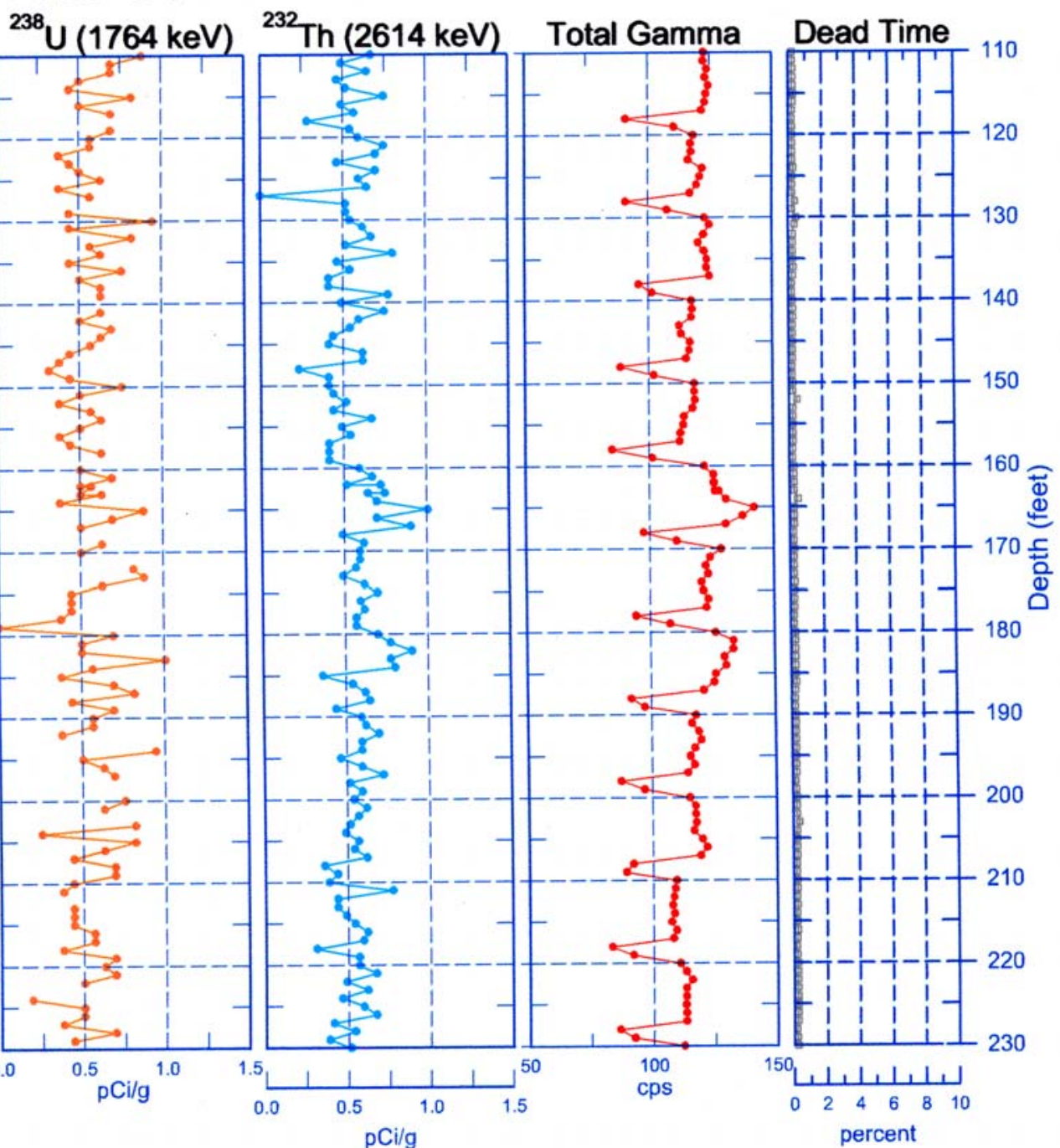

Zero Reference $=$ Ground Surface 

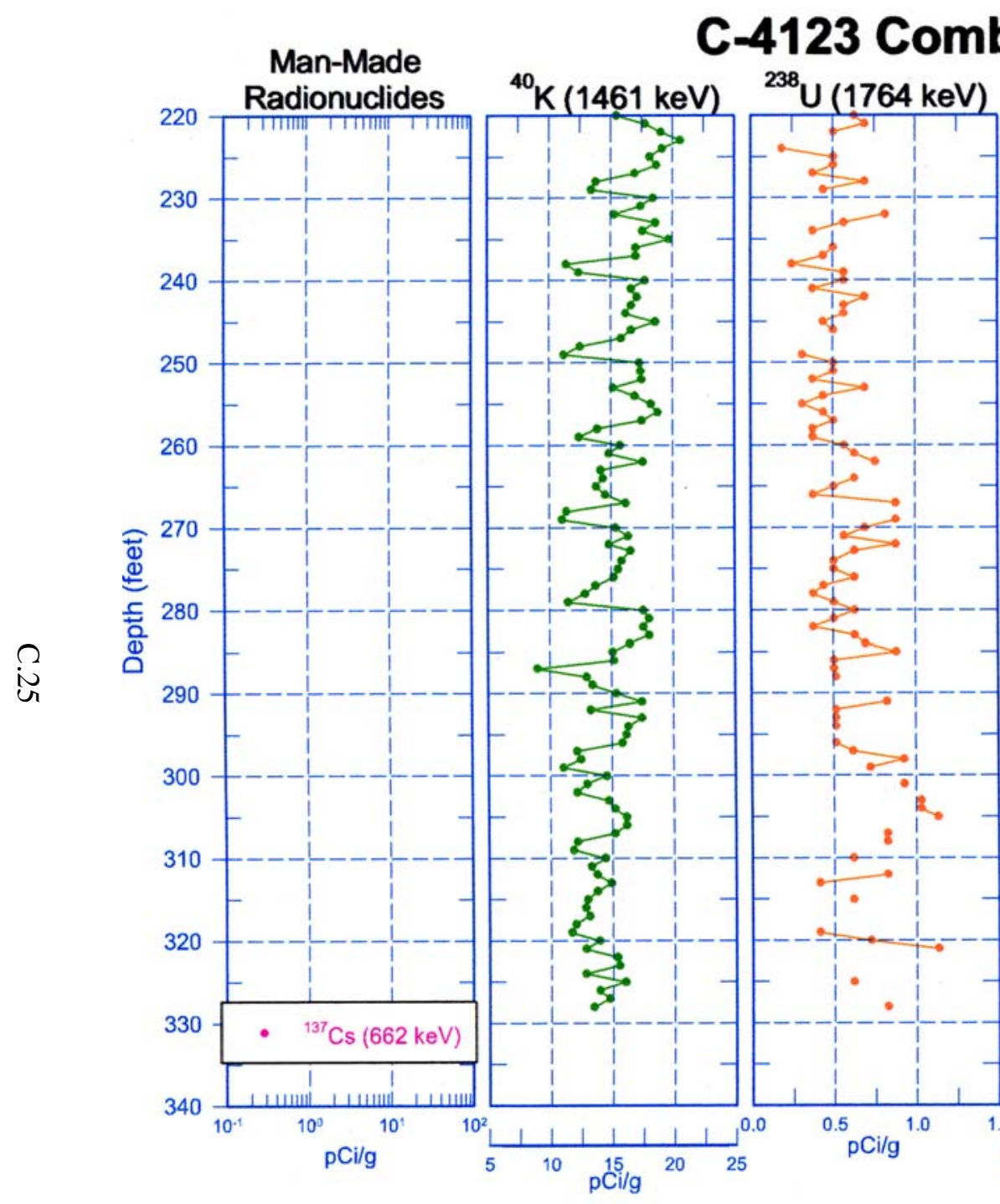

C-4123 Combination Plot

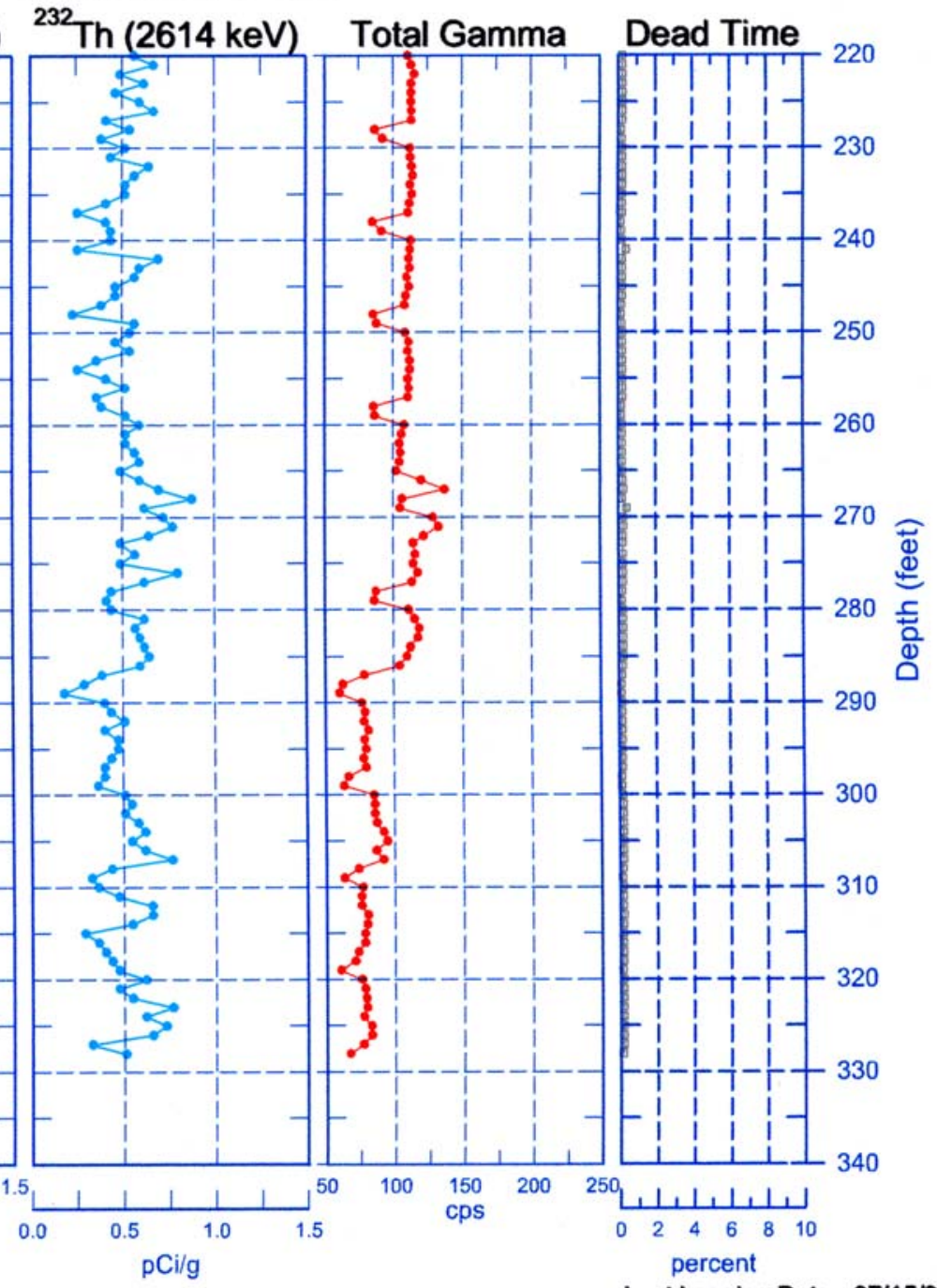

Zero Reference $=$ Ground Surface

Last Logging Date - 07/15/03 


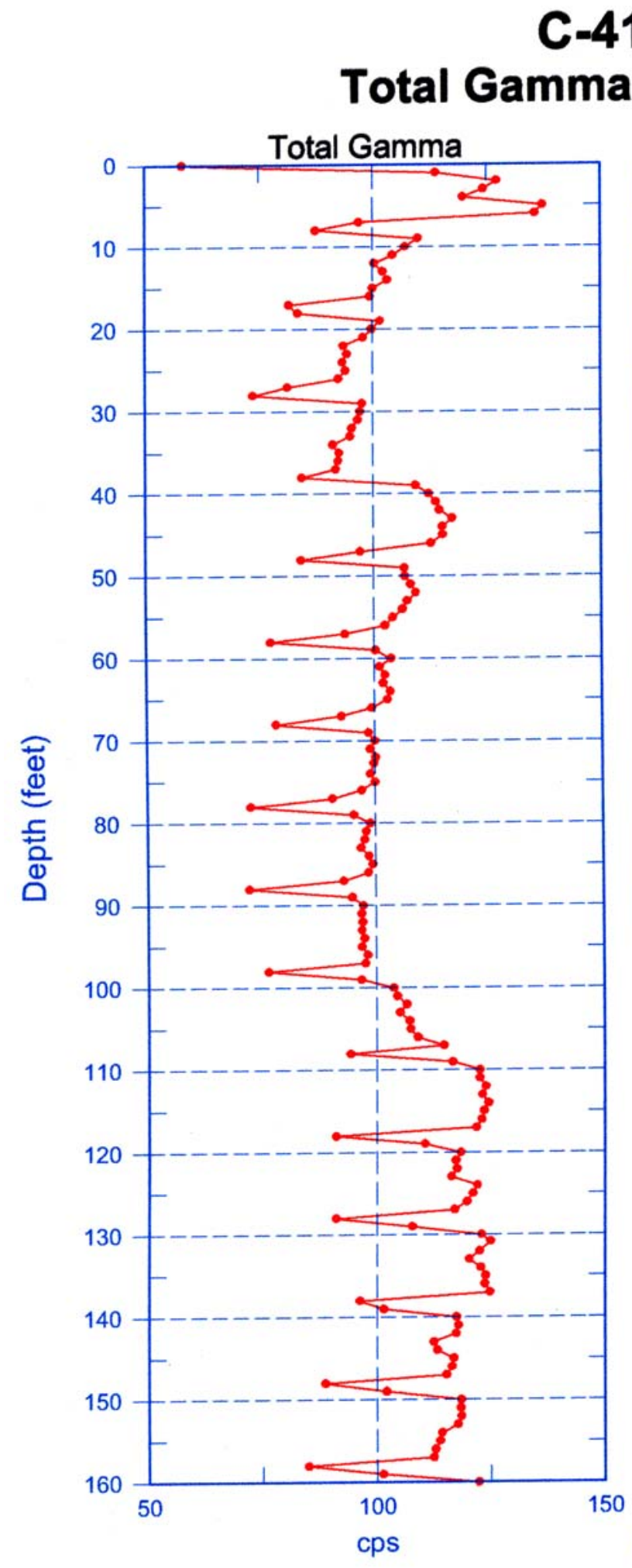

Reference - Ground Surface

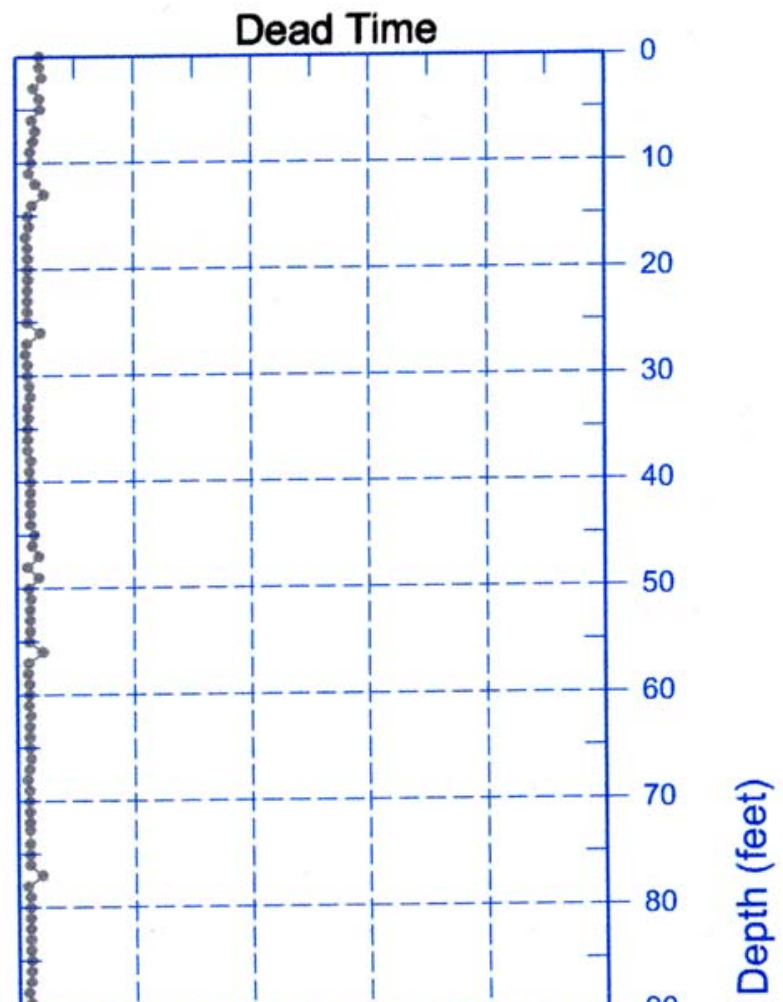

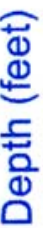




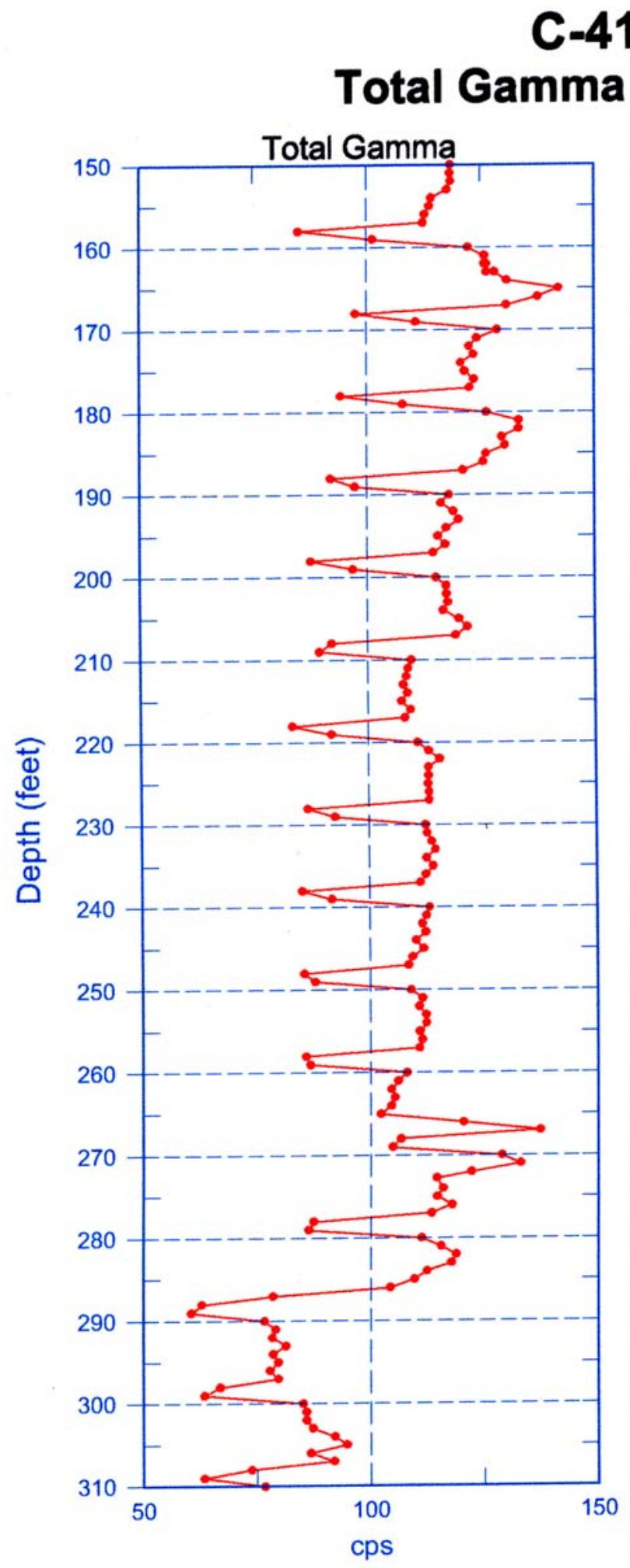

Reference - Ground Surface

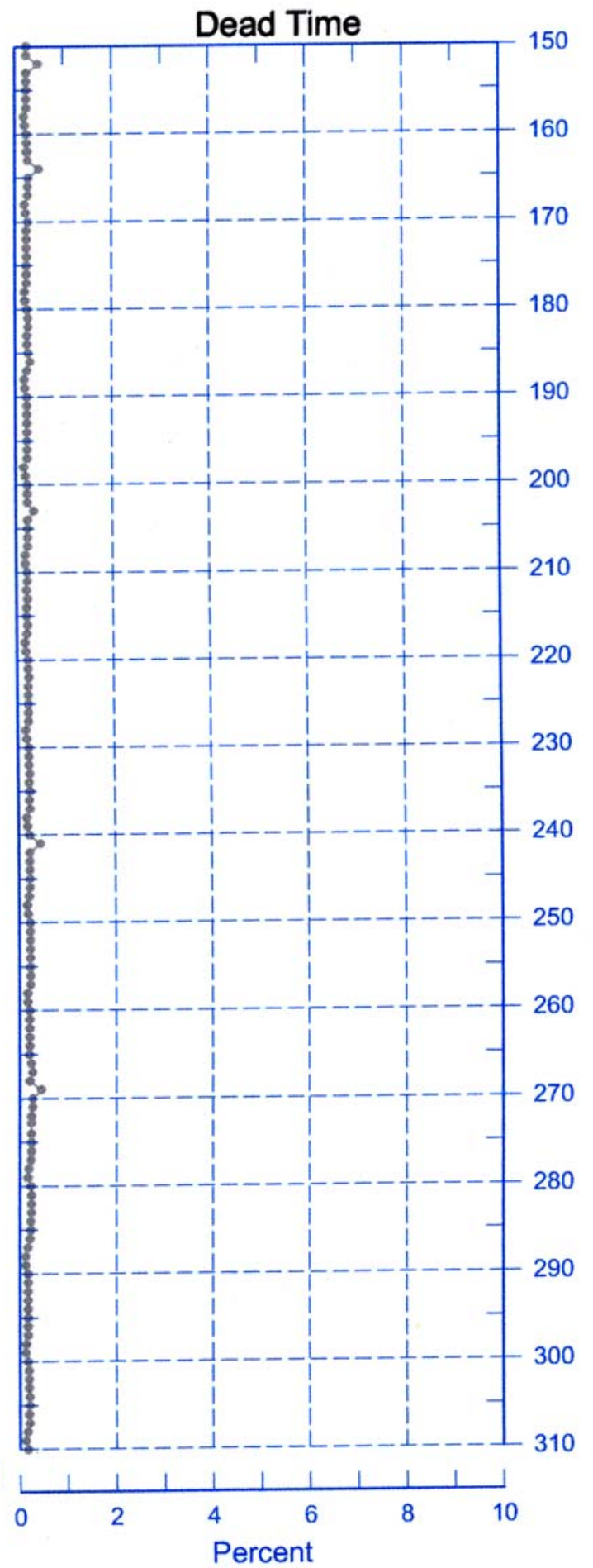

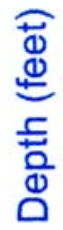

Last Log Date - 07/15/03 


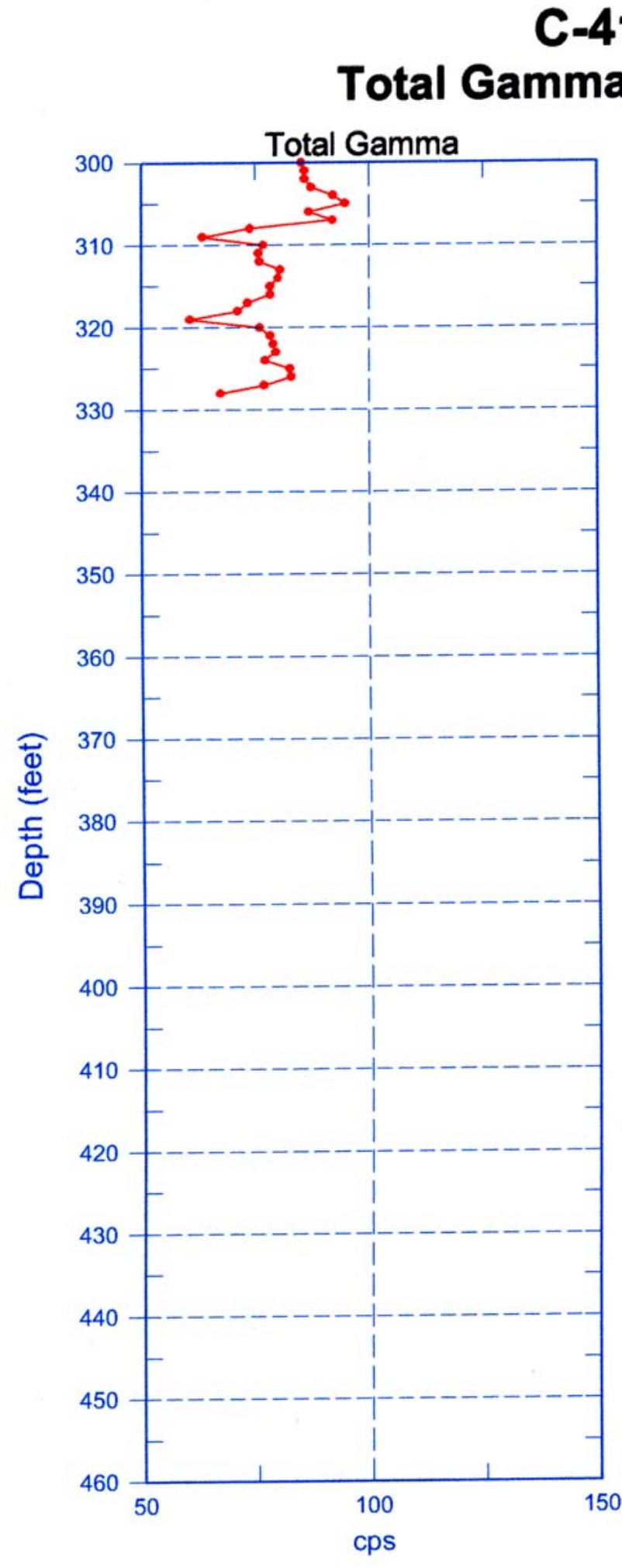

Reference - Ground Surface

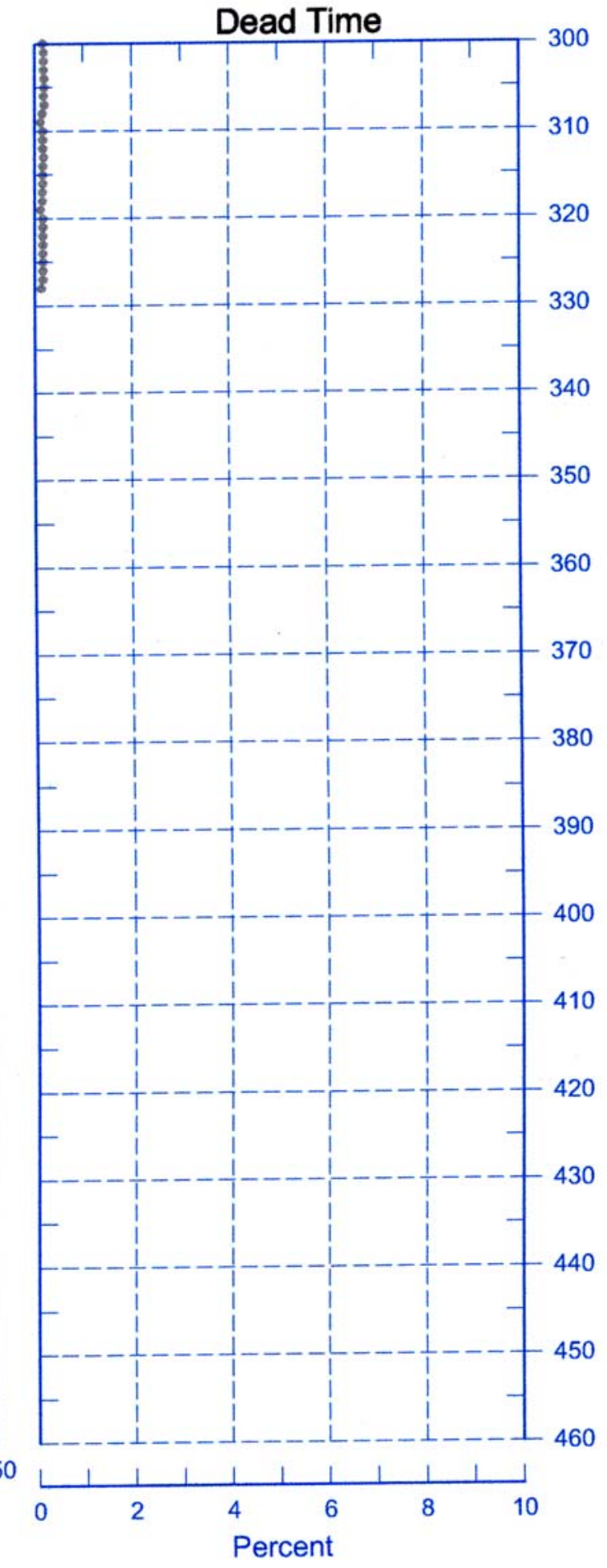

Last Log Date - 07/15/03 


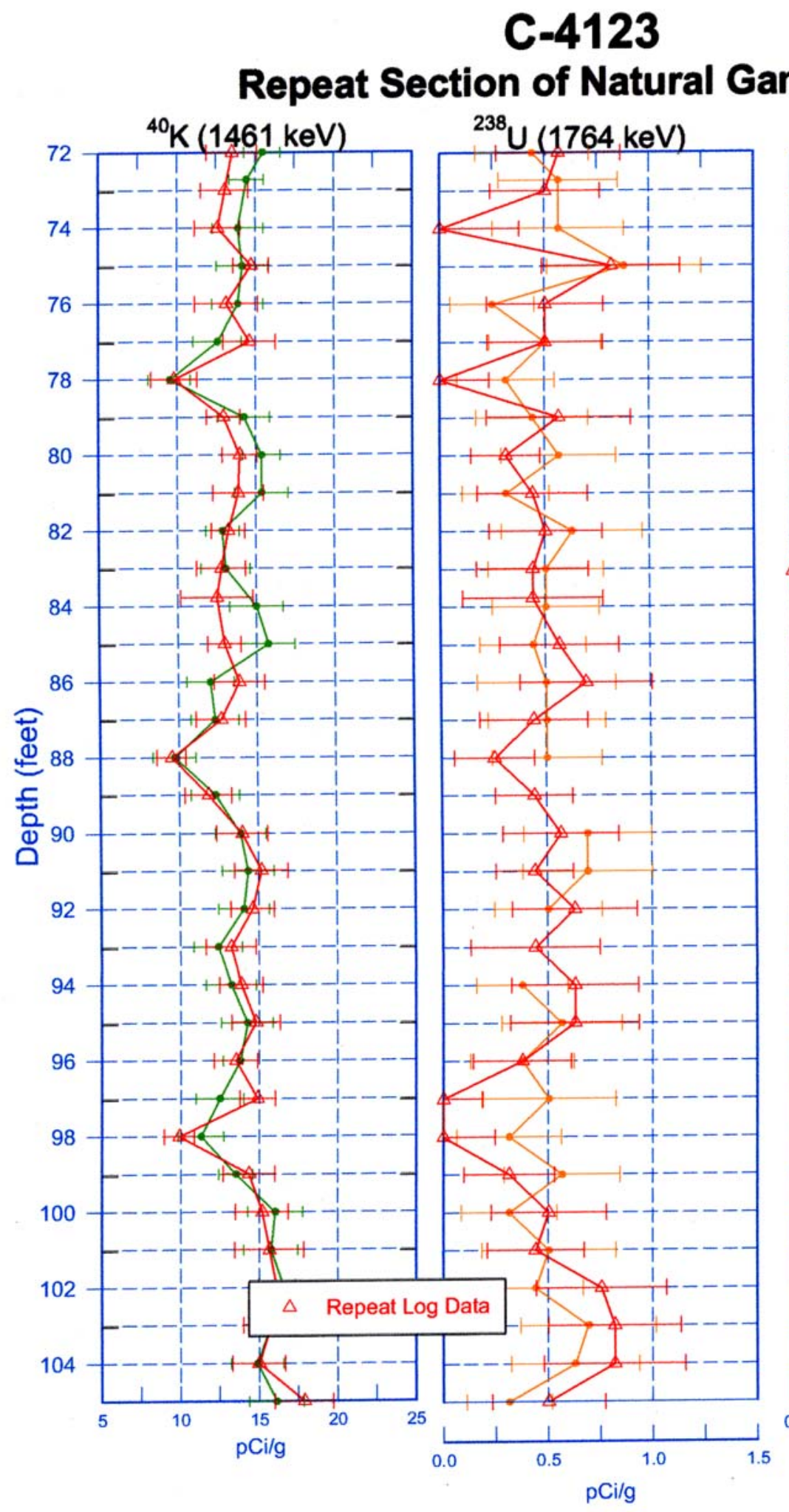

Gamma Logs

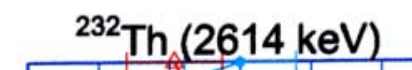

72
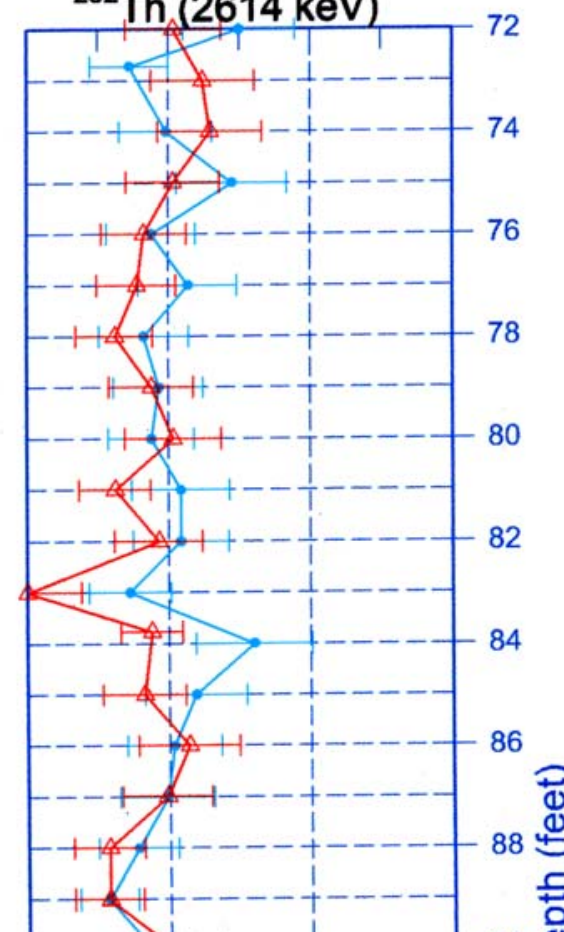

ชิ $8 \stackrel{\oplus}{ \pm}$
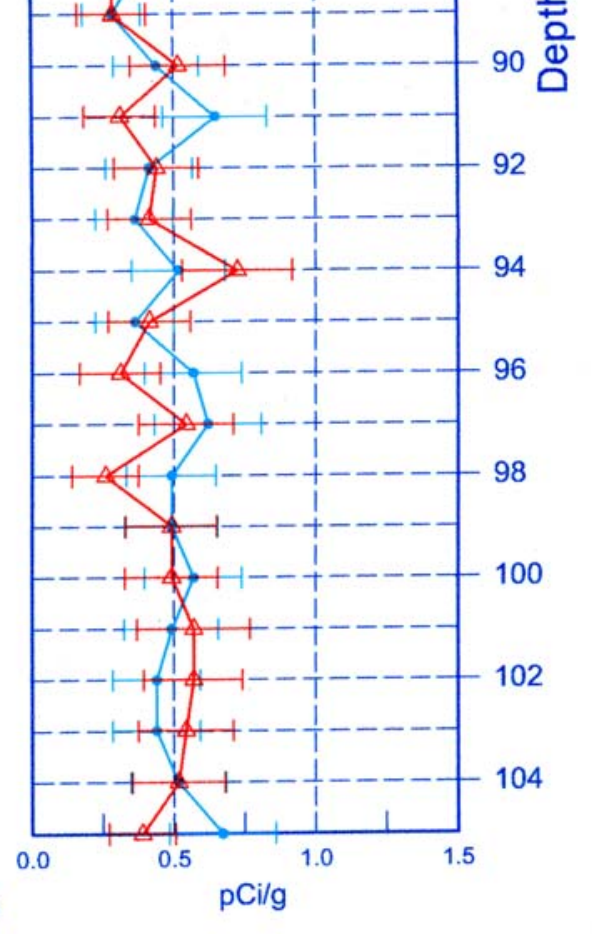

Last Log Date - 07/15/03

Zero Reference $=$ Ground Surface

C.29 
Table C.1. Gyroscope Data Report for Borehole C4122

\begin{tabular}{|c|c|c|c|c|c|c|c|c|c|c|c|c|c|}
\hline 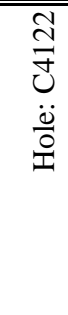 & 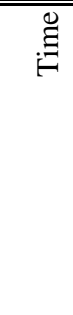 & 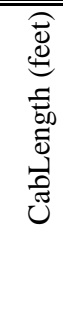 & 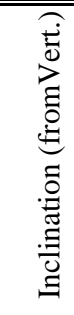 & 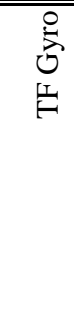 & 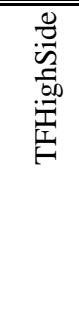 & 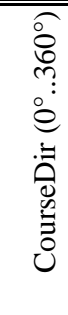 & 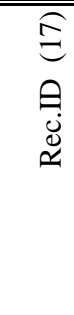 & 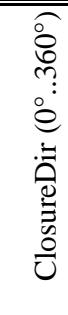 & 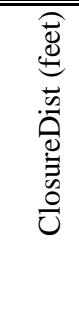 & 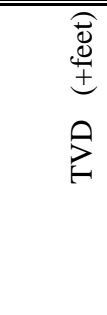 & 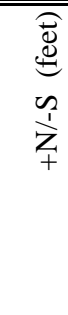 & 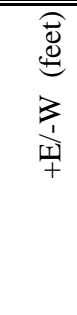 & 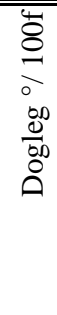 \\
\hline $2 \mathrm{~S}$ & 3.18 & 0 & 0.13 & 34.1 & 333 & 214 & $2 \mathrm{~S}$ & 0 & 0 & 0 & 0 & 0 & 0 \\
\hline $3 \mathrm{~S}$ & 4.33 & 20 & 0.17 & 301 & 0 & 94.2 & $3 \mathrm{~S}$ & 142 & 0.03 & 20 & -0 & 0.02 & 1.3 \\
\hline $4 \mathrm{~S}$ & 5.18 & 40 & 0.23 & 313 & 14.4 & 92.3 & $4 \mathrm{~S}$ & 106 & 0.09 & 40 & -0 & 0.09 & 0.3 \\
\hline $5 \mathrm{~S}$ & 5.98 & 60 & 0.34 & 267 & 355 & 65.4 & $5 \mathrm{~S}$ & 90.4 & 0.18 & 60 & 0 & 0.18 & 0.8 \\
\hline $6 \mathrm{~S}$ & 6.67 & 80 & 0.47 & 297 & 14.2 & 76.8 & $6 \mathrm{~S}$ & 82.3 & 0.32 & 80 & 0.04 & 0.31 & 0.8 \\
\hline $7 \mathrm{~S}$ & 7.28 & 100 & 0.36 & 356 & 62.2 & 87.6 & $7 \mathrm{~S}$ & 82.1 & 0.46 & 100 & 0.06 & 0.45 & 0.7 \\
\hline $8 \mathrm{~S}$ & 7.98 & 120 & 0.48 & 50.1 & 125 & 78.5 & $8 \mathrm{~S}$ & 82.1 & 0.6 & 120 & 0.08 & 0.6 & 0.7 \\
\hline $9 \mathrm{~S}$ & 8.7 & 140 & 0.62 & 64.1 & 141 & 77.3 & $9 \mathrm{~S}$ & 81.1 & 0.8 & 140 & 0.12 & 0.79 & 0.7 \\
\hline $10 \mathrm{~S}$ & 9.24 & 160 & 0.34 & 85.8 & 175 & 64.5 & $10 \mathrm{~S}$ & 79.7 & 0.96 & 160 & 0.17 & 0.95 & 1.5 \\
\hline $11 \mathrm{~S}$ & 9.88 & 180 & 0.76 & 110 & 202 & 62.3 & $11 \mathrm{~S}$ & 76.9 & 1.15 & 180 & 0.26 & 1.12 & 2.1 \\
\hline $12 \mathrm{~S}$ & 10.4 & 200 & 0.35 & 120 & 235 & 39.3 & $12 \mathrm{~S}$ & 73.9 & 1.33 & 199.99 & 0.37 & 1.27 & 2.3 \\
\hline $13 \mathrm{~S}$ & 11.2 & 220 & 0.76 & 165 & 268 & 50.9 & $13 \mathrm{~S}$ & 70.6 & 1.5 & 219.99 & 0.5 & 1.42 & 2.2 \\
\hline $14 \mathrm{~S}$ & 11.9 & 240 & 0.66 & 213 & 314 & 53.3 & $14 \mathrm{~S}$ & 68 & 1.74 & 239.99 & 0.65 & 1.61 & 0.6 \\
\hline $15 \mathrm{~S}$ & 12.8 & 260 & 0.66 & 244 & 317 & 81.5 & $15 \mathrm{~S}$ & 67.9 & 1.96 & 259.99 & 0.74 & 1.82 & 1.6 \\
\hline $16 \mathrm{~S}$ & 13.5 & 280 & 0.68 & 249 & 318 & 84.7 & $16 \mathrm{~S}$ & 69.5 & 2.19 & 279.99 & 0.76 & 2.05 & 0.2 \\
\hline $17 \mathrm{~S}$ & 14.1 & 300 & 0.9 & 284 & 290 & 148 & $17 \mathrm{~S}$ & 74.1 & 2.34 & 299.99 & 0.64 & 2.25 & 4.3 \\
\hline $18 \mathrm{~S}$ & 17.2 & 305 & 0.96 & 264 & 265 & 153 & $18 \mathrm{~S}$ & 76 & 2.36 & 304.99 & 0.57 & 2.29 & 2 \\
\hline
\end{tabular}


Table C.2. Gyroscope Data Report for Borehole C4123

\begin{tabular}{|c|c|c|c|c|c|c|c|c|c|c|c|c|c|}
\hline 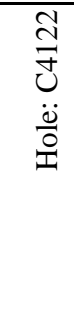 & 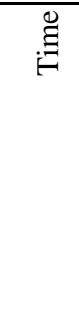 & 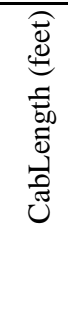 & 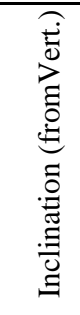 & \begin{tabular}{l}
\multirow{3}{3}{} \\
号 \\
出
\end{tabular} & 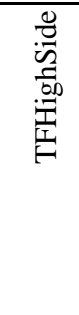 & 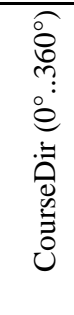 & 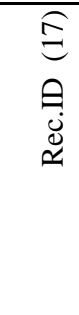 & 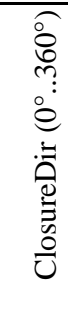 & 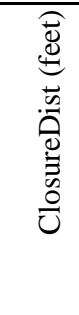 & 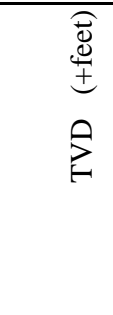 & 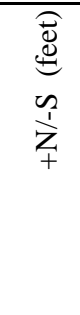 & 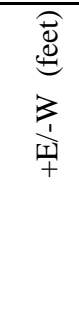 & 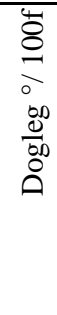 \\
\hline $2 S$ & 3.18 & 0 & 0.13 & 34.1 & 333 & 214 & $2 \mathrm{~S}$ & 0 & 0 & 0 & 0 & 0 & 0 \\
\hline $3 \mathrm{~S}$ & 4.33 & 20 & 0.17 & 301 & 0 & 94.2 & $3 \mathrm{~s}$ & 142 & 0.03 & 20 & -0 & 0.02 & 1.3 \\
\hline $4 \mathrm{~S}$ & 5.18 & 40 & 0.23 & 313 & 14.4 & 92.3 & $4 \mathrm{~S}$ & 106 & 0.09 & 40 & -0 & 0.09 & 0.3 \\
\hline $5 \mathrm{~S}$ & 5.98 & 60 & 0.34 & 267 & 355 & 65.4 & $5 \mathrm{~S}$ & 90.4 & 0.18 & 60 & 0 & 0.18 & 0.8 \\
\hline $6 \mathrm{~S}$ & 6.67 & 80 & 0.47 & 297 & 14.2 & 76.8 & $6 \mathrm{~S}$ & 82.3 & 0.32 & 80 & 0.04 & 0.31 & 0.8 \\
\hline $7 \mathrm{~S}$ & 7.28 & 100 & 0.36 & 356 & 62.2 & 87.6 & $7 \mathrm{~S}$ & 82.1 & 0.46 & 100 & 0.06 & 0.45 & 0.7 \\
\hline $8 \mathrm{~S}$ & 7.98 & 120 & 0.48 & 50.1 & 125 & 78.5 & $8 \mathrm{~S}$ & 82.1 & 0.6 & 120 & 0.08 & 0.6 & 0.7 \\
\hline $9 \mathrm{~S}$ & 8.7 & 140 & 0.62 & 64.1 & 141 & 77.3 & $9 \mathrm{~S}$ & 81.1 & 0.8 & 140 & 0.12 & 0.79 & 0.7 \\
\hline $10 \mathrm{~S}$ & 9.24 & 160 & 0.34 & 85.8 & 175 & 64.5 & $10 \mathrm{~S}$ & 79.7 & 0.96 & 160 & 0.17 & 0.95 & 1.5 \\
\hline $11 \mathrm{~S}$ & 9.88 & 180 & 0.76 & 110 & 202 & 62.3 & $11 \mathrm{~S}$ & 76.9 & 1.15 & 180 & 0.26 & 1.12 & 2.1 \\
\hline $12 \mathrm{~S}$ & 10.4 & 200 & 0.35 & 120 & 235 & 39.3 & $12 \mathrm{~S}$ & 73.9 & 1.33 & 199.99 & 0.37 & 1.27 & 2.3 \\
\hline $13 \mathrm{~S}$ & 11.2 & 220 & 0.76 & 165 & 268 & 50.9 & $13 \mathrm{~S}$ & 70.6 & 1.5 & 219.99 & 0.5 & 1.42 & 2.2 \\
\hline $14 \mathrm{~S}$ & 11.9 & 240 & 0.66 & 213 & 314 & 53.3 & $14 \mathrm{~S}$ & 68 & 1.74 & 239.99 & 0.65 & 1.61 & 0.6 \\
\hline $15 \mathrm{~S}$ & 12.8 & 260 & 0.66 & 244 & 317 & 81.5 & $15 \mathrm{~S}$ & 67.9 & 1.96 & 259.99 & 0.74 & 1.82 & 1.6 \\
\hline $16 \mathrm{~S}$ & 13.5 & 280 & 0.68 & 249 & 318 & 84.7 & $16 \mathrm{~S}$ & 69.5 & 2.19 & 279.99 & 0.76 & 2.05 & 0.2 \\
\hline $17 \mathrm{~S}$ & 14.1 & 300 & 0.9 & 284 & 290 & 148 & $17 \mathrm{~S}$ & 74.1 & 2.34 & 299.99 & 0.64 & 2.25 & 4.3 \\
\hline $18 \mathrm{~S}$ & 17.2 & 305 & 0.96 & 264 & 265 & 153 & $18 \mathrm{~S}$ & 76 & 2.36 & 304.99 & 0.57 & 2.29 & 2 \\
\hline
\end{tabular}

